\title{
CONTROLE DO DESENVOLVIMENTO DAS HASTES NO CAPIM TANZÂNIA: UM DESAFIO
}

PATRICIA MENEZES SANTOS

Tese apresentada à Escola Superior de Agricultura "Luiz de Queiroz", Universidade de São Paulo, para obtenção do título de Doutor em Agronomia, Área de Concentração: Ciência Animal e Pastagens.

P I R A C I C A B A

Estado de São Paulo - Brasil

Janeiro - 2002 


\title{
CONTROLE DO DESENVOLVIMENTO DAS HASTES NO CAPIM TANZÂNIA: UM DESAFIO
}

\section{PATRICIA MENEZES SANTOS}

\author{
Engenheiro Agrônomo
}

Orientador: Prof. Dr. MOACYR CORSI

\begin{abstract}
Tese apresentada à Escola Superior de Agricultura "Luiz de Queiroz", Universidade de São Paulo, para obtenção do título de Doutor em Agronomia, Área de Concentração: Ciência Animal e Pastagens.
\end{abstract}

P I R A C I C A B A

Estado de São Paulo - Brasil

Janeiro - 2002 
Dados Internacionais de Catalogação na Publicação (CIP) DIVISÃO DE BIBLIOTECA E DOCUMENTAÇÃO - ESALQ/USP

\footnotetext{
Balastreire, Luiz Antonio

Avanços na agricultura de precisão no Brasil no período de 1999-2001 / Luiz Antonio Balastreire. - - Piracicaba : L.A. Balastreire, 2002.

347 p. : il.

1. Agricultura de precisão 2. GPS. 3. Mapeamento 4. Mecanização agrícola I. Título CDD 631.3
}

"Permitida a cópia total ou parcial deste documento, desde que citada a fonte - O autor" 
Aos meus pais,

Maria Amélia e Roberto,

por sua dedicação e carinho

Dedico. 


\section{AGRADECIMENTOS}

- Ao Prof. Dr. Moacyr Corsi e ao Dr. Barry Thornton, pela contribuição para a minha formação e pela orientação na condução deste trabalho.

- Ao Eng. Agr. Marco Antônio Alvares Balsalobre, pela ajuda, incentivo e paciência, principalmente nos momentos mais difíceis da condução deste trabalho.

- Aos colegas de pós graduação Marco Antônio Penati e Daniel Pagotto, pelo auxílio no desenvolvimento deste trabalho.

- Ao pesquisadores e funcionários do "Macaulay Land Use Research Institute", pelo auxílio no desenvolvimento deste trabalho.

- Aos estagiário do Projeto CAPIM, pelo auxílio no desenvolvimento deste trabalho.

- À Prof. Clarice Demétrio, ao Prof. César Gonçalves Lima e aos alunos de pós graduação Telde Natel Custódio e Ramiro Ruiz Cardenas, pelo auxílio na realização da análise estatística.

- Ao técnico do Laboratório de Bromatologia da ESALQ-USP, Carlos César Alves, pelo auxílio na realização das análises bromatológicas.

- Ao Prof. Dr. Vidal Pedroso de Faria, pela contribuição para a minha formação.

- Aos meus irmãos, Anneliese, Cristiana, Edgard, Maria Carmen e Roberto, pelo incentivo para a realização deste trabalho.

- À Fundação de Amparo à Pesquisa do Estado de São Paulo e ao SEERAD pelo suporte financeiro para a execução deste trabalho. 


\section{SUMÁRIO}

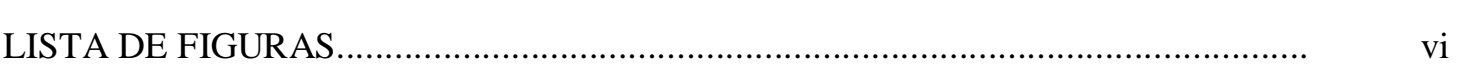

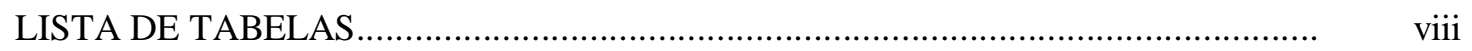

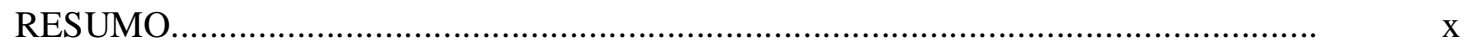

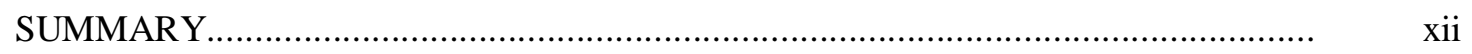

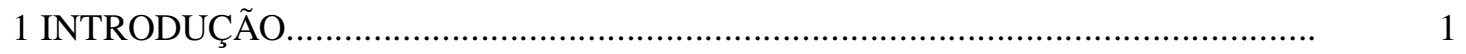

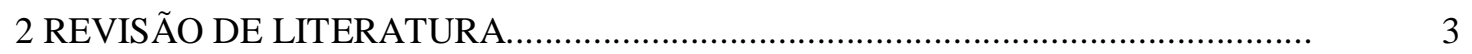

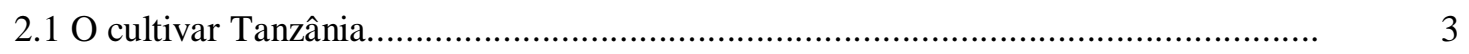

2.2 Importância do controle da produção de hastes......................................................... 5

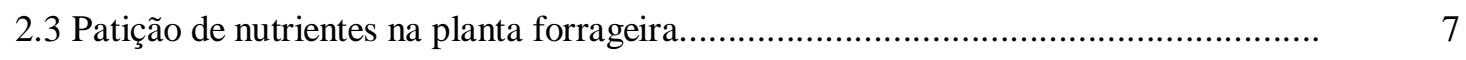

2.3.1 Mecanismos de partição de carboidratos na planta................................................. 7

2.3.2 Fatores que interferem na partição de carboidratos: importância e limitações........... 11

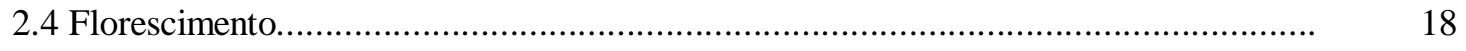

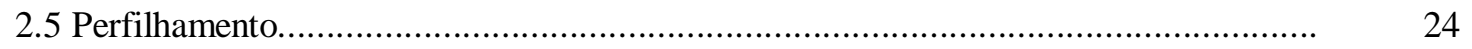

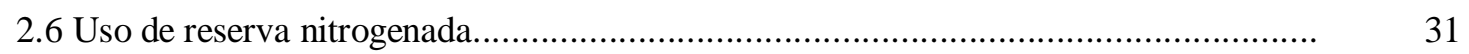

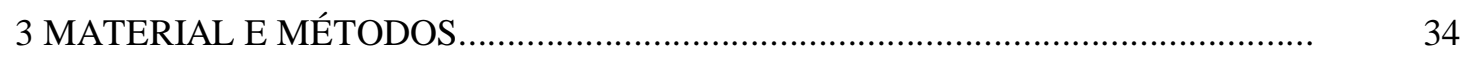

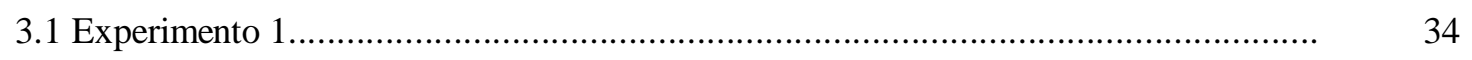

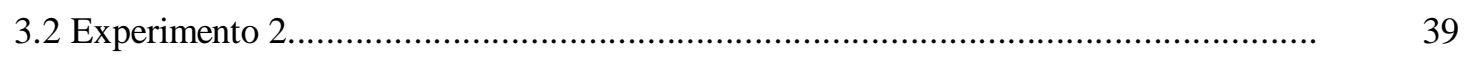

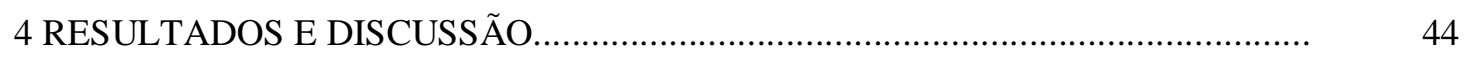

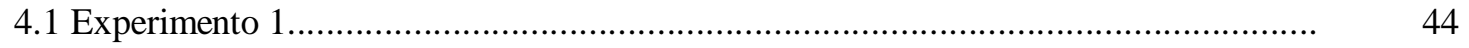

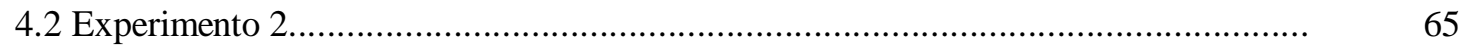

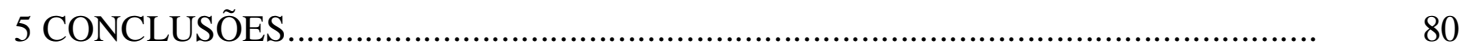

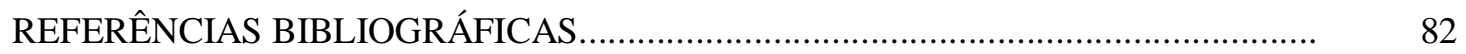




\section{LISTA DE FIGURAS}

Página

1 Temperatura máxima, mínima e média mensal $\left({ }^{\circ} \mathrm{C}\right)$ de outubro de 1999 a junho de 2000.

2 Forma de marcação dos perfilhos com fio de arame.

3 Câmara de crescimento com vasos de capim Tanzânia.

4 Separação da planta de capim Tanzânia.

5 Efeito da intensidade de pastejo sobre a participação das gerações no número total de perfilhos do capim Tanzânia no: (a) ciclo 4; (b) ciclo 5; e (c) ciclo 6. Os números acima das colunas representam a contribuição da geração em porcentagem do número total de perfilhos. As barras correspondem ao erro padrão da média

6 Efeito da intensidade de pastejo sobre a participação de cada geração na massa de forragem do capim Tanzânia no: (a) ciclo 4; e (b) ciclo 5. Os número acima das colunas representam a contribuição da geração em porcentagem da massa de forragem total. As barras correspondem ao erro padrão da média

7 Efeito da intensidade de pastejo sobre a proporção de folhas e hastes de cada geração do capim Tanzânia no: (a) ciclo 4; e (b) ciclo 5. As barras representam o erro padrão da média...

8 Efeito da intensidade de pastejo sobre a participação de cada geração na massa de folhas do capim Tanzânia no: (a) ciclo 4; e (b) ciclo 5. Os número acima das colunas representam a contribuição de cada geração em porcentagem da massa de folhas total. As barras correspondem ao erro padrão da média. 
9 Efeito da intensidade de pastejo sobre a participação de cada geração na massa de hastes do capim Tanzânia no: (a) ciclo 4; e (b) ciclo 5. Os número acima das colunas representam a contribuição de cada geração em porcentagem da massa de hastes total. As barras correspondem ao erro padrão da média.

10 Massa seca total do capim Tanzânia $\left(\mathrm{g} / \mathrm{planta}^{-1}\right)$. Os símbolos fechados correspondem ao tratamento $+\mathrm{N}$ e os abertos ao zero $\mathrm{N}$. As barras, quando maiores que os símbolos, representam o erro padrão da média.

11 Conteúdo de $\mathrm{N}$ total do capim Tanzânia $\left(\mathrm{mg} / \mathrm{planta}^{-1}\right)$. Os símbolos fechados correspondem ao tratamento $+\mathrm{N}$ e os abertos ao zero $\mathrm{N}$. As barras, quando maiores que os símbolos, representam o erro padrão da média

12 Conteúdo de $\mathrm{N}$ marcado $(\bullet$ tratamento $+\mathrm{N} ; \diamond$ tratamento zero $\mathrm{N}$ ) e não marcado $(\bullet$ tratamento $+\mathrm{N} ;$ O tratamento zero N) de plantas de capim Tanzânia, expresso em mg.planta ${ }^{-1}$. As barras, quando maiores que os símbolos, representam o erro padrão da média.

13 Variação no conteúdo total de $\mathrm{N}$ de partes da planta de capim Tanzânia: (a) diferença entre a primeira e a segunda coleta do tratamento $+\mathrm{N}$; (b) diferença entre a segunda e a terceira coleta do tratamento $+\mathrm{N}$; (c) diferença entre a primeira e a segunda coleta do tratamento zero $\mathrm{N}$; (d) diferença entre a segunda e a terceira coleta do tratamento zero N. As barras, quando maiores que os símbolos, representam o erro padrão da diferença.

14 Variação no conteúdo de $\mathrm{N}$ não marcado (mobilização) de partes da planta de capim Tanzânia do tratamento $+\mathrm{N}$ : (a) diferença entre a primeira e a segunda coleta; (b) diferença entre a segunda e a terceira coleta. As barras, quando maiores que os símbolos, representam o erro padrão da diferença............................................

15 Variação no conteúdo de $\mathrm{N}$ marcado (absorção) de partes da planta de capim Tanzânia do tratamento $+\mathrm{N}$ : (a) diferença entre a primeira e a segunda coleta; (b) diferença entre a segunda e a terceira coleta. As barras, quando maiores que os símbolos, representam o erro padrão da diferença 


\section{LISTA DE TABELAS}

Página

1 Data inicial dos ciclos de pastejo de cada bloco............................................ 36

2 Resíduo pós pastejo obtido durante o período experimental........................... 36

3 Número total de perfilhos do capim Tanzânia submetido a três intensidades de pastejo ao longo dos ciclos (outubro/1999 a junho/2000).........................

4 Efeito do ciclo de pastejo sobre o número de perfilhos das quatro primeiras gerações do capim Tanzânia submetido a três intensidades de pastejo (alta, média e baixa).

5 Efeito da intensidade de pastejo sobre o número de perfilhos da segunda e sexta gerações do capim Tanzânia.

6 Efeito do ciclo de pastejo sobre o peso médio dos perfilhos das gerações de capim Tanzânia submetido a três intensidades de pastejo (alta, média e baixa).......

7 Efeito da intensidade de pastejo sobre o peso médio por perfilho da geração

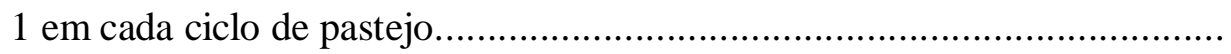

8 Efeito da intensidade e do ciclo de pastejo sobre a massa de forragem das gerações de perfilhos do capim Tanzânia.

9 Efeito do ciclo de pastejo sobre a porcentagem de folhas das três primeiras gerações de perfilhos do capim Tanzânia submetido a três intensidades de pastejo (alta, média e baixa).

10 Efeito da intensidade e do ciclo de pastejo sobre a porcentagem de folhas da quarta geração de perfilhos do capim Tanzânia. 
11 Efeito da intensidade e do ciclo de pastejo sobre a massa de folhas das gerações de perfilhos do capim Tanzânia

12 Efeito da intensidade e do ciclo de pastejo sobre a massa de hastes das gerações de perfilhos do capim Tanzânia.....................................................

13 Efeito do ciclo de pastejo sobre a digestibilidade "in vitro"da matéria orgânica das gerações de perfilhos do capim Tanzânia.

14 Efeito da intensidade de pastejo sobre a digestibilidade "in vitro" da matéria orgânica das gerações de perfilhos do capim Tanzânia.

15 Efeito da intensidade e do ciclo de pastejo sobre a digestibilidade "in vitro"da matéria orgânica da segunda geração de perfilhos do capim Tanzânia

16 Massa seca (g.planta ${ }^{-1}$ ) das partes da planta de capim Tanzânia recebendo ou não nitrogênio.

17 Uso relativo de nitrogênio proveniente da absorção radicular e da remobilização nos principais drenos de nitrogênio do capim Tanzânia entre

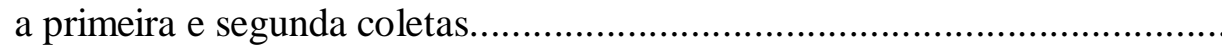

18 Uso relativo de nitrogênio proveniente da absorção radicular e da remobilização nos principais drenos de nitrogênio do capim Tanzânia entre

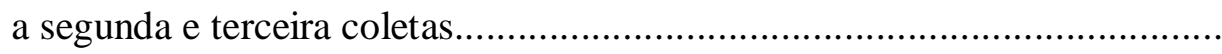

19 Uso relativo de nitrogênio proveniente da absorção radicular e da remobilização nos principais drenos de nitrogênio do capim Tanzânia entre

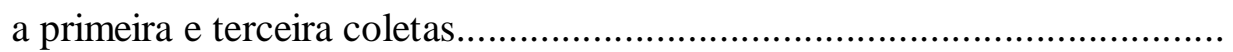




\title{
CONTROLE DA PRODUÇÃO DE HASTES NO CAPIM TANZÂNIA: UM DESAFIO
}

\author{
Autora: PATRICIA MENEZES SANTOS \\ Orientador: Prof. Dr. MOACYR CORSI
}

\section{RESUMO}

O capim Tanzânia (Panicum maximum Jacq. cv. Tanzânia) tem sido amplamente utilizado em áreas de pastagem no Brasil. O aumento da participação das hastes na produção, no entanto, têm efeito negativo sobre a qualidade da forragem e a eficiência do pastejo, principalmente durante o florescimento. $\mathrm{O}$ objetivo deste trabalho foi gerar informações sobre o perfilhamento e a dinâmica interna de nitrogênio, de modo a permitir a proposição de estratégias de manejo visando o controle do desenvolvimento das hastes. Para isso foram realizados dois experimentos. O primeiro em área de capim Tanzânia irrigado na ESALQ/USP, em PiracicabaSP, entre outubro/1999 e junho/2000. O delineamento experimental foi de blocos ao acaso com três tratamentos (intensidade de pastejo alta, média e baixa) e quatro repetições. Foram avaliados: número; peso; porcentagem de folhas; participação na produção total, de folhas e de hastes; e a DIVMO das gerações de perfilhos. O segundo experimento foi realizado em câmaras de crescimento no MLURI, em Aberdeen-Escócia. O capim Tanzânia foi cultivado em vasos, recebendo solução nutritiva completa até que a $7^{\underline{a}}$ folha estivesse expandida. A partir de então, passou a receber solução nutritiva semelhante, alguns com ${ }^{15} \mathrm{~N}$ e outros com zero N. As plantas foram coletadas no momento da completa expansão das folhas 7, 8 e 9, e separadas em suas 
partes constituintes. As amostras foram secadas, pesadas, moídas e depois analisadas quanto às concentrações de $\mathrm{N}$ total e de ${ }^{15} \mathrm{~N}$, utilizando-se espectrômetro de massa de fluxo contínuo. Nenhuma geração de perfilhos destacou-se em termos de participação na massa de forragem total, não sendo possível programar o manejo do capim Tanzânia com base nas caraterísticas de uma única geração. A porcentagem de folhas dependeu, principalmente, do estádio de desenvolvimento do capim e do ciclo de pastejo. Não é possível, portanto, controlar o desenvolvimento das hastes através de cortes estratégicos que eliminem determinadas gerações de perfilhos. A participação das gerações de perfilhos na produção de hastes dependeu da intensidade de pastejo, sendo a participação das gerações mais novas maior no pastejo mais intenso. A DIVMO das gerações diminuiu com a idade e, de modo geral, foi maior nas áreas submetidas a alta intensidade de pastejo. Estratégias de manejo que promovam maior renovação de perfilhos a partir de fevereiro parecem boas alternativas para reduzir os efeitos negativos do florescimento. No entanto, é preciso observar suas conseqüências sobre a produção animal e a perenidade do pasto. No capim Tanzânia, os principais drenos de nitrogênio foram as folhas em expansão, seguidas dos perfilhos laterais e raízes. As folhas expandidas mais novas representaram a principal fonte de nitrogênio para mobilização. A alocação da maior parte do nitrogênio em órgãos de fácil acesso à colheita demonstra a necessidade de estudos sobre a dinâmica de nitrogênio em plantas submetidas a desfolha. Este processo pode limitar a adoção de práticas de manejo que promovam maior renovação na população de perfilhos. A absorção radicular foi a principal fonte de $\mathrm{N}$, demonstrando a necessidade de estudos sobre o sistema radicular e a dinâmica de nitrogênio no sistema solo-planta. 


\title{
STEMS PRODUCTION CONTROL ON TANZANIA GRASS: A CHALLENGE
}

\author{
Author: PATRICIA MENEZES SANTOS \\ Adviser: Prof. Dr. MOACYR CORSI
}

\section{SUMMARY}

Tanzânia grass (Panicum maximum Jacq. cv. Tanzânia) is widely used for grazing in Brazil. The increase in stem production, mainly during flowering, has a negative impact over forage quality and grazing efficiency. The aim of this work was to study tillering and nitrogen dynamics in order to propose management alternatives for the control of stem production. Two experiments were done. The first was on an irrigated Tanzânia grass pasture at ESALQ/USP, in Piracicaba-SP, between October/1999 and June/2000. The experiment was on a complete block design with three treatments (high, medium and low grazing intensities) and four replicates. Tiller cohorts were identified by coloured plastic coated wire. The number weight leaf percentage contribution to total production and to leaf and stem production, and IVOMD of each cohort were evaluated throughout the experiment. The second experiment was conducted on the MLURI, in Aberdeen-Scotland. Tanzânia grass plants were grown in sand culture in controlled environment rooms and supplied with a complete nutrient solution until the $7^{\text {th }}$ leaf was fully expanded. From then on, the plants received either an identical solution containing ${ }^{15} \mathrm{~N}$ or a complete nutrient solution containing zero $\mathrm{N}$. They were destructively harvested and separated into various components when the $7^{\text {th }}, 8^{\text {th }}$ and $9^{\text {th }}$ leaves were fully expanded. All plant material was weighted 
after oven drying at $65^{\circ} \mathrm{C}$, and then ball-milled prior to analysis. The total $\mathrm{N}$ and ${ }^{15} \mathrm{~N}$ concentrations of the samples were determined using a continuous flow mass spectrometer. No tiller cohort was identified as responsible for most of dry mass production, so it is not possible to base Tanzânia grass management on the characteristics of a single cohort. The percentage of leaves was mainly related to plant development stage and grazing cycle. The contribution of tiller cohorts to stem production was influenced by grazing intensities: the participation of the youngest cohorts was higher on heavily grazed areas. The IVOMD of tiller cohorts decreased over the grazing cycles and was higher on heavily grazed areas. Obtaining a higher tiller turnover through management practices seems to be the best way to reduce the negative effects of flowering over forage quality and grazing efficiency. The consequences of these management strategies over pasture persistence and animal production need to be established. The main sinks of nitrogen on Tanzânia grass were expanding leaves, followed by side tillers and roots. The youngest fully expanded leaves were the main sources of nitrogen for mobilisation. As most nitrogen is allocated to plant compartments easily harvested by grazing, studies about nitrogen dynamics on defoliated plants are necessary to verify these effects over pasture regrowth and persistence. This process may limit the adoption of management strategies that increase tiller turnover. Root uptake was the main source of nitrogen for new growth, indicating the necessity of more studies on root development and nitrogen dynamics on soil-plant system. 


\section{INTRODUÇÃO}

O Brasil, por se encontrar em região de clima tropical, apresenta elevado potencial de produção de forragem. Apesar disso, os níveis de produtividade da pecuária nacional são baixos. Valores como: lotação animal de 0,5 UA.ha ${ }^{-1} \cdot$ ano $^{-1} ; 50 \%$ de natalidade; produção de $55 \mathrm{~kg} \cdot \mathrm{ha}^{-}$ ${ }^{1}$. ano ${ }^{-1}$ de carcaça e de $300 \mathrm{~kg} \cdot \mathrm{ha}^{-1}$. ano $^{-1}$ de leite são citados freqüentemente na literatura (Corsi, 1986). Esses baixos índices podem ser atribuídos, em parte, à não utilização de técnicas adequadas de manejo de pastagem.

Desde seu lançamento pela Empresa Brasileira de Pesquisa Agropecuária (Embrapa) em 1990, o uso do capim Tanzânia (Panicum maximum Jacq. cv. Tanzânia) em áreas comerciais têm aumentado. No entanto, apesar do crescente número de experimentos envolvendo este cultivar, vários aspectos de seu manejo ainda precisam ser elucidados.

Um dos principais problemas relacionados ao manejo do capim Tanzânia é o aumento da participação das hastes na produção, principalmente durante o período do florescimento. Este cultivar floresce, normalmente, no período do outono (abril/maio). Durante o processo de florescimento, ocorre o alongamento das hastes, que exercem um efeito negativo sobre o valor alimentar da forragem.

É provável que os efeitos negativos do florescimento possam ser minimizados através de práticas específicas de manejo. A determinação destes métodos, no entanto, depende do conhecimento de algumas características relacionadas à fisiologia e ecofisiologia do cultivar como a fisiologia de florescimento e a dinâmica de perfilhamento. Além disso, o capim Tanzânia é tido como exigente em fertilidade e susceptível a pastejos freqüentes e intensos. Qualquer alternativa de manejo proposta deve, portanto, levar em consideração o seu efeito sobre a perenidade do pasto. 
O objetivo deste trabalho foi gerar informações sobre o perfilhamento e a dinâmica interna de nitrogênio no capim Tanzânia, de modo a permitir a proposição de estratégias de manejo visando o controle do desenvolvimento das hastes. 


\section{REVISÃO DE LITERATURA}

\subsection{0 cultivar Tanzânia}

O capim Tanzânia (BRA-007218) foi coletado pelo "Institut Français de Recherche Scientifique pour le Développement en Coopération" (ORSTOM) em Korogwe, na Tanzânia. O lançamento comercial desse capim em 1990, foi fruto de um longo trabalho de seleção coordenado pela Embrapa (Jank et al., 1994; Jank, 1995).

O capim Tanzânia "é uma planta cespitosa com altura média de 1,3 m e folhas decumbentes com largura média de 2,6 cm. Lâminas e bainhas são glabras, sem cerosidade. Os colmos são levemente arroxeados. As inflorescências são do tipo panícula, com ramificações primárias longas, e secundárias longas apenas na base. As espiguetas são arroxeadas, glabras e uniformemente distribuídas. O vertículo é glabro" (Savidan et al., 1990).

O potencial de utilização deste capim pode ser verificado através dos resultados obtidos durante a avaliação dos acessos no banco de germoplasma da Embrapa Gado de Corte. O capim Tanzânia produziu 33 t.ha ${ }^{-1}$.ano ${ }^{-1}$ de matéria seca total, sendo 26 t.ha $^{-1}$.ano ${ }^{-1}$ de matéria seca foliar (80\%), e teve, em média, 12,7\% de proteína bruta nas folhas e 9\% nos colmos (Savidan et al., 1990; Jank et al., 1994; Jank, 1995). No entanto, este potencial nem sempre tem sido convertido em produção animal.

Na literatura são encontrados dados de: taxa de lotação variando de 1,0 a 9,0 UA.ha ${ }^{-}$

${ }^{1}$.ano ${ }^{-1}$ (Costa et al., 2000; Penati et al., 2001; Brâncio et al., 2001); e ganho de peso por animal variando de menos 0,100 a 0,800 kg.animal ${ }^{-1} \cdot \mathrm{dia}^{-1}$ (Euclides et al., 1999a; Agulhon et al., 2001; Brâncio et al., 2001). As variações em áreas comerciais são ainda maiores, sendo que em alguns casos são observados ganhos de peso negativos durante o período das "secas" e taxas de lotação abaixo de 1 UA.ha $^{-1}$.ano ${ }^{-1}$. 
O capim Tanzânia apresenta elevada estacionalidade de produção. Em um experimento conduzido por Cecato et al. (1996), onde os cortes eram feitos a cada 35 dias no verão e 70 no

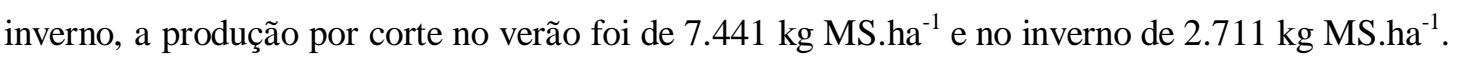
Santos et al. (1999) observaram que a taxa de acúmulo de matéria seca do capim Tanzânia aumentou de 79,8 kg MS.ha ${ }^{-1} \cdot \mathrm{dia}^{-1} \mathrm{em}$ setembro/novembro para 150,1 kg MS.ha- ${ }^{-1} \cdot \mathrm{dia}^{-1} \mathrm{em}$ janeiro/fevereiro, voltando a diminuir para 96,1 kg MS.ha- ${ }^{-1} \cdot \mathrm{dia}^{-1} \mathrm{em}$ fevereiro/abril. Essa variação no nível de produção de matéria seca ao longo do ano é um dos motivos para a baixa produtividade observada em algumas áreas.

Outro motivo parece ser o nível de perda de forragem durante e entre os pastejos. Quadros et al. (2001) relatam perdas de até $42 \%$ da matéria seca total na planta e $14 \%$ no chão em pastagens de capim Tanzânia. Nesse experimento, as perdas apresentaram correlação positiva com a adubação nitrogenada.

As perdas de forragem em uma pastagem estão relacionadas ao manejo e estrutura do pasto, ao estádio de desenvolvimento do capim e à época do ano.

A fertilidade do solo também interfere no nível de produtividade. O Panicum maximum é considerado uma espécie exigente em fertilidade. A maior produção de matéria seca do capim Tanzânia devida à adubação nitrogenada têm sido relatada por diversos autores (Forni et al., 2000; Queiroz Neto, 2001). Euclides et al. (1999a) observaram que a taxa de lotação e produtividade foram maiores para o capim Tanzânia recebendo uma adubação de 100 kg N.ha ${ }^{-}$ ${ }^{1}$. ano ${ }^{-1}$ comparado a $50 \mathrm{~kg} \mathrm{~N} \cdot \mathrm{ha}^{-1} \cdot \mathrm{ano}^{-1}$. Nesse experimento houve uma acréscimo de 1,9 kg de peso vivo.ha ${ }^{-1}$. ano ${ }^{-1}$ para cada kg adicional de $\mathrm{N}$ aplicado.

A adubação nitrogenada, no entanto, pode alterar a estrutura do pasto. Forni et al. (2000) observaram que a adubação nitrogenada aumentou a massa de hastes no estrato de 0 a $50 \mathrm{~cm}$ e a de folhas no estrato acima de $50 \mathrm{~cm}$. O desenvolvimento das hastes pode interferir no valor alimentar da forragem.

Brâncio et al. (2000) observaram que o tamanho do bocado no capim Tanzânia estava relacionado à proporção de folhas verdes e à qualidade da forragem. Nesse experimento, os maiores tamanhos de bocado ocorreram no início do período chuvoso, associados à maior proporção de folhas verdes e à melhor qualidade do pasto. Além disso, Euclides et al. (1999b) observaram que as características estruturais do pasto (disponibilidade de folhas e relação entre material verde e material morto) tiveram mais influência sobre o consumo de matéria seca, o 
tempo de pastejo e o ganho de peso dos animais que as variáveis relacionadas ao valor nutritivo da forragem.

As variáveis estruturais do pasto dependem do manejo, do estádio de desenvolvimento do capim e da época do ano. Santos et al. (1999) observaram que a relação folha : haste do capim Tanzânia foi maior com um intervalo entre pastejos de 48 dias do que de 28 dias no período de novembro/dezembro. Em janeiro/fevereiro, não houve efeito do intervalo entre pastejos sobre a proporção de folhas e hastes e, a partir de fevereiro, a relação folha : haste diminuiu com o aumento do intervalo entre pastejos. A maior proporção de hastes nesse experimento foi observada em abril/maio, durante o período do florescimento.

No experimento de Euclides et al. (1999b) o ganho de peso e consumo dos animais foi maior durante o período das "águas", quando havia uma maior proporção de folhas e material verde.

\subsection{Importância do controle da produção de hastes}

O manejo do pasto é planejado visando vários objetivos como: proporcionar rebrota vigorosa e favorecer perenidade do pasto; obter elevada produção de matéria seca e sincronizar disponibilidade e necessidade de forragem; atingir elevado nível de aproveitamento da forragem produzida, reduzindo as perdas por senescência e aumentando a eficiência de colheita; produzir e colher forragem de boa qualidade. Além disso, no últimos anos têm aumentado a preocupação com a sustentabilidade do sistema e do meio ambiente. A importância relativa de cada um destes objetivos vai depender do sistema de produção e do contexto em que está inserido.

O desenvolvimento das hastes favorece o aumento da produção de matéria seca, no entanto, pode ter efeitos negativos sobre o aproveitamento e a qualidade da forragem produzida. Parsons et al. (1988) ressaltam a importância de se controlar a produção de hastes no pasto, alegando que sua presença pode reduzir a eficiência do sistema de duas formas: limitando a capacidade de colheita da forragem pelo animal ou reduzindo o seu valor alimentar. Korte et al. (1982), concluíram que, durante a fase reprodutiva, o manejo de pastagens de azevém (Lolium perenne L.) deveria ser determinado com o objetivo de controlar o desenvolvimento reprodutivo e 
que o índice de área foliar e a interceptação luminosa não são critérios adequados de manejo para essa época.

Em gramíneas forrageiras, o alongamento das hastes é, normalmente, concomitante ao florescimento. Nesse período, a relação folha : haste diminui rapidamente, pois além do crescimento das hastes ser maior, o aparecimento de folhas cessa após o lançamento das inflorescências. Em Panicum maximum Jacq. cvs. Tanzânia e Mombaça, por exemplo, foi observado que as hastes chegavam a representar $70 \%$ da matéria seca disponível entre abril e maio (época do florescimento) (Santos et al., 1999). Para o capim elefante (Pennisetum purpureum Schum.), Balsalobre (1996) observou que em abril (início do florescimento) as hastes correspondiam a $66 \%$ da matéria seca disponível.

Trabalhos com plantas temperadas têm demonstrado que a profundidade do horizonte de pastejo é limitada pela altura das hastes (Barthram \& Grant, 1984; Flores et al., 1993). Existem poucos estudos relacionando o comportamento de pastejo à presença das hastes em plantas tropicais, porém não há dúvida de que elas limitam a capacidade de colheita da forragem pelos animais.

Além disso, a altura das hastes está relacionada à quantidade de perdas devido ao pastejo. Hillesheim (1988) determinou que se perdia 49,35 kg.ha ${ }^{-1}$ de matéria seca para cada centímetro de aumento na altura do meristema apical do capim elefante. Essas perdas são decorrentes da ação do trânsito dos animais sobra a planta forrageira, fazendo com que os perfilhos tombem e fiquem mais sujeitos ao pisoteio.

No capim Tanzânia, Santos (1997) determinou que comprimento das hastes chegou a 1,49 m no período do florescimento, demonstrando a necessidade de estudos que relacionem esta característica ao consumo animal e às perdas por pastejo nesse cultivar.

Alguns trabalhos têm mostrado que as plantas tropicais apresentam uma grande heterogeneidade vertical em termos de densidade, proporção de partes da planta e valor nutritivo, sendo que o tamanho do bocado parece estar relacionado, principalmente, à porcentagem de folhas, massa seca de folhas e/ou massa seca verde do estrato superior do dossel. A maneira como as folhas são apresentadas aos animais e a facilidade com que estas podem ser colhidas separadas das hastes e do material morto também parece ser importante (Euclides et al., 1999b; Sollenberger \& Burns, 2001). 
O valor nutritivo das folhas cai mais lentamente que o das hastes com o aumento da idade do capim (Andrade, 1987; Singh, 1995). No início da estação de crescimento o valor nutritivo das hastes e folhas é semelhante, porém a haste apresenta uma queda acentuada de qualidade com o passar do tempo. Em capim elefante, por exemplo, a extensão da degradação das hastes é semelhante à das folhas no início da estação de crescimento, porém a redução na extensão de degradação das hastes com o avanço da estação é mais acentuada que nas folhas (Balsalobre, 1996).

Tecidos vasculares e esclerênquima apresentam pouca ou nenhuma degradação. Em Panicum maximum Jacq. cv. Trichoglume, esses tecidos corresponderam a $8 \%$ dos tecidos da lâmina foliar, $10 \%$ da nervura das folhas, $15 \%$ da bainha e $20 \%$ das hastes. Por outro lado, tecidos de elevada digestibilidade como parênquimas e mesófilos representam 53\% da lâmina, $18 \%$ da nervura das folhas, $11 \%$ da bainha e $4 \%$ da haste (Wilson, 1993). A maior porcentagem de tecidos de baixa degradabilidade é uma das razões para o menor valor alimentar das hastes.

As folhas apresentam um tempo de retenção no trato digestivo inferior ao das hastes, o que permite que o consumo de folhas seja maior, mesmo quando os níveis de digestibilidade, fibra em detergente neutro, fibra em detergente ácido e lignina são semelhantes (Poppi et al., 1981; Forbes \& Coleman, 1993).

\subsection{Partição de nutrientes na planta forrageira}

\subsubsection{Mecanismos de partição de carboidratos na planta}

Para se compreender melhor a importância da partição de carboidratos e como essa informação pode ser utilizada com o objetivo de maximizar a produtividade dos pastos é necessário se conhecer os mecanismos envolvidos.

O transporte de carboidratos na planta é feito através do floema, que é formado pelos elementos crivados, pelas células companheiras e pelo parênquima. Os elementos crivados são células vivas com o protoplasma modificado (são formados pela membrana plasmática, mitocôndrias, plastídios e retículo endoplasmático). Além disso, a parede celular dos elementos 
crivados não é lignificada. A principal característica dos elementos crivados é a presença de placas crivadas que permitem a interligação de diversas células, formando o tubo crivado por onde circulam os fotoassimilados. As células companheiras apresentam uma estreita interligação com os elementos crivados (são originadas da mesma célula mãe) e um protoplasma completo, o que sugere que elas forneçam suporte metabólico para os elementos crivados. (Taiz \& Zeiger, 1991; Hopkins, 1995).

O transporte de carboidratos é feito sempre de uma fonte para um dreno. Todos os órgãos de uma planta, em algum estádio de seu desenvolvimento, funcionam como dreno. Apenas alguns órgãos (ex: folhas) passam de dreno para fonte. (Taiz \& Zeiger, 1991; Hopkins, 1995).

A conversão de uma folha de dreno para fonte é gradual e acompanha o processo de maturação, sendo que a exportação de carboidratos se inicia antes que a importação tenha cessado nas regiões em desenvolvimento. Existem evidências de que a importação de carboidratos cessa devido à interrupção do descarregamento do floema na folha, sendo que essa interrupção e a capacidade de exportar carboidratos são praticamente irreversíveis. Com isso, a planta evita que folhas sombreadas ou velhas se tornem drenos metabólicos, o que seria indesejável. (Turgeon, 1989; Taiz \& Zeiger, 1991).

O mecanismo de translocação no floema se inicia com o carregamento dos carboidratos na fonte. Ainda existe muita controvérsia a respeito do mecanismo de transporte dos carboidratos das células do mesófilo foliar até o floema, sendo que ainda não foi esclarecido se esse segue a via simplástica ou apoplástica. De qualquer forma, a seiva encontrada no interior do floema é diferente daquela encontrada nos tecidos à sua volta, o que sugere a existência de um mecanismo seletivo de carregamento de carboidratos. (Taiz \& Zeiger, 1991; Hopkins, 1995).

Após o carregamento, os fotoassimilados seguem pelo floema até a região do dreno. Existem várias hipóteses que procuram explicar esse transporte, sendo que a do fluxo de massa é mais aceita.

Segundo a hipótese do fluxo de massa, o fluxo de seiva ao longo do floema é governado por um potencial de pressão entre a fonte e o dreno, gerado pelo carregamento de sacarose na fonte e descarregamento no dreno. Isto é, o carregamento de sacarose na fonte aumenta o potencial osmótico levando à entrada de água. Com isso o potencial de pressão se eleva. No dreno, o descarregamento da sacarose leva a uma redução do potencial osmótico, com a consequiente saída de água e redução do potencial pressão. Desse modo, forma-se um gradiente de 
pressão entre a fonte e o dreno que determina o transporte da seiva por fluxo de massa. (Taiz \& Zeiger, 1991; Hopkins, 1995).

O mecanismo de descarregamento de carboidratos nos drenos também não foi ainda bem esclarecido, e aparentemente pode ocorrer pelas vias simplástica ou apoplástica. Segundo Patrick (1990) existem evidencias de que a forma de descarregamento dependa da função do dreno e de que o descarregamento por via apoplástica só ocorre quando o descarregamento pela via simplástica não é compatível com a função do dreno (ex: armazenamento de solutos osmaticamente ativos contra um gradiente de concentração e potencial hídrico entre o floema e as células do dreno). Ainda segundo o mesmo autor, o descarregamento no dreno por via simplástica deve ser integrado a algum mecanismo de compartimentalização ou metabolização do soluto descarregado.

A translocação de carboidratos nas plantas segue alguns padrões gerais: as fontes exportam carboidratos para os drenos mais próximos; a partição de carboidratos e a importância relativa dos drenos muda ao longo do ciclo da planta, de acordo com a distribuição espacial dos tecidos em crescimento (durante a fase vegetativa os meristemas apical e radicular são mais importantes, mas durante a fase reprodutiva os frutos se tornam os drenos preferenciais); as fontes enviam fotoassimilados para drenos com os quais mantêm conexões vasculares diretas. A alteração nas vias de translocação através de danos às plantas alteram os padrões descritos. Além disso, existem evidências de que cada categoria de folha desempenha um papel específico no crescimento da planta, a depender de sua idade e posição.(Taiz \& Zeiger, 1991; Hopkins, 1995; Preston, 1998).

Para Gifford et al. (1984) existem evidências de que a taxa fotossintética e os mecanismos de carregamento no floema determinam a quantidade de fotoassimilados disponível para translocação, enquanto os mecanismos e a dinâmica de descarregamento nos drenos, associado à distância entre as fontes e drenos, determinam a partição de carboidratos a curto prazo.

Muitos pesquisadores têm desenvolvido trabalhos com o objetivo de determinar se a produção de determinada cultura é limitada pela fonte (quantidade de fotoassimilados disponível) ou pelo número de drenos. Minchin et al. (1994) trabalhando com cevada (Hordeum distichum (L.) Lam.) concluíram que a partição de carboidratos entre os drenos dependia tanto do fornecimento de fotoassimilados quanto da função do dreno. Marcelis (1996), no entanto, acredita 
que a partição de carboidratos entre os drenos é regulada por eles próprios, sendo que o efeito da fonte é indireto, na medida em que interfere na formação dos drenos. Já Farrar (1996) coloca que não é possível prever o fluxo de fotoassimilados em um dreno sem levar em consideração o resto do sistema de transporte (fonte, floema e dreno).

Marcelis (1996) ressalta a importância de se estabelecer um parâmetro para a avaliação da "força" do dreno, que descreva sua capacidade de importar carboidratos independente do resto da planta.

Alguns pesquisadores têm proposto que a força de um dreno pode ser determinada através de seu tamanho (massa total do tecido) e atividade (taxa de importação de fotoassimilados) (Taiz \& Zeiger, 1991; Marcelis, 1996). No entanto, Minchin \& Thorpe (1996) afirmam que a taxa de fluxo de carboidratos para um dreno depende de outros fatores, além do dreno propriamente dito, como: suprimento de carboidratos, presença de outros drenos e resistência ao transporte ao longo do floema. Desta forma, a taxa de fluxo de carboidratos é uma propriedade do sistema como um todo, não podendo ser utilizada na descrição de apenas um dreno.

Wardlaw (1990) acredita que algumas características de determinado órgão podem ser vantajosas com relação ao controle da partição de nutrientes: tamanho da superfície de membranas através da qual metabólitos são transferidos do sistema vascular para a zona de utilização (área de descarregamento); eficiência de transferência de carboidratos do sistema vascular para o dreno; isolamento espacial e/ou bioquímico dos fotoassimilados nos órgãos em crescimento ou de reserva depois que eles deixam o sistema vascular. Talvez essas e outras características possam ser utilizadas na caracterização dos drenos.

Vários modelos têm sido desenvolvidos com o intuito de explicar a partição de carboidratos entre a parte aérea e a raiz nas plantas. Os modelos alométricos propõem uma relação fixa entre a taxa de crescimento das raízes e da parte aérea, enquanto os modelos de equilíbrio funcional se baseiam na taxa de atividade das raízes e da parte aérea. Apesar de serem empíricos (ou seja, não explicam os mecanismos através do qual a planta atinge o equilíbrio proposto), esses modelos são úteis em estudos cujo objetivo é verificar o efeito de determinados fatores sobre a relação parte aérea : raiz de determinada planta. $\mathrm{O}$ modelo de Thornley é baseado na assimilação e transporte de carbono e nitrogênio e têm sido utilizado para explicar a resposta das plantas a fatores como: deficiência hídrica e mineral, luminosidade, nível de $\mathrm{CO}_{2}$, desfolha e 
redução do sistema radicular. Os modelos hormonais sugerem que as raízes produzem substâncias que regulam o crescimento da parte aérea e vice-versa, porém as evidências atuais mostram que este não é o principal mecanismo de controle em plantas normais (Wilson, 1988; Caloin, 1994).

Sem dúvida ainda existem muitos pontos a serem esclarecidos com relação ao funcionamento do sistema de partição de nutrientes na planta. No entanto, com o avanço das pesquisas e o desenvolvimento de novas técnicas experimentais essas lacunas deverão ser preenchidas.

\subsubsection{Fatores que interferem na partição de carboidratos: importância e limitações.}

O carbono fixado através da fotossíntese pode ser utilizado na respiração, perdido por lixiviação ou distribuído entre o sistema radicular, parte vegetativa e parte reprodutiva. A partição desses carboidratos depende de uma série de fatores genéticos, fisiológicos e do meio, que, em alguns casos, podem ser manipulados de modo a aumentar a produtividade da cultura em questão.

Wilson \& Jones (1982), trabalhando com populações de azevém que apresentavam diferentes taxas de respiração determinaram que uma redução de $20 \%$ na taxa respiratória dos tecidos maduros levava a um aumento de aproximadamente $10 \%$ na produção. A menor taxa de respiração dessas populações parece estar relacionada à redução na respiração de manutenção. No entanto, os autores levantaram uma série de questões que devem ser resolvidas antes que se possa considerar a taxa respiratória como um critério de seleção de cultivares: pode haver alguma característica associada à taxa de respiração que seja indesejável; altas taxas de respiração talvez sejam interessantes em alguns ambientes; não se sabe se essa característica irá persistir ao longo das gerações.

Após a assimilação, os carboidratos podem ser utilizados para: síntese e armazenamento no cloroplasto ou síntese de sacarose no citoplasma. Essa divisão é importante em termos de partição de nutrientes, pois a sacarose é um dos principais determinantes da exportação de carboidratos da folha e o amido um dos principais carboidratos de reserva. A sacarose pode ser convertida em uma série de compostos nos tecidos. A regulação desse processo parece ser por enzimas e proteínas transportadoras. A manipulação genética do nível de enzimas nos "compartimentos celulares" ou a alteração de algumas características das membranas envolvidas 
nesses processos podem ser formas de alterar a partição de carboidratos na planta (Gifford et al., 1984; Blakeley \& Dennis, 1993; Geiger et al., 1996).

Os mecanismos internos de controle determinam um padrão de distribuição de carboidratos de acordo com o estádio de desenvolvimento da planta. Parsons \& Robson (1981) verificaram que em pastos de azevém ("pastagem estabelecida") em estádio reprodutivo ocorria uma redução acentuada na porcentagem de carboidratos locada para o sistema radicular, coincidindo com o início do alongamento das hastes. Nas áreas recém implantadas, onde o capim não sofreu vernalização e, conseqüentemente, não passou para o estádio reprodutivo, essa alteração na partição de carboidratos não foi observada. Também trabalhando com azevém, Colvill \& Marshal (1984) observaram que há uma hierarquia entre os perfilhos e que a competição por fotoassimilados aumenta à medida que o pasto se estabelece. Estes autores determinaram que a competição é mais acentuada durante a fase de florescimento, quando os perfilhos principais investem a maior parte dos fotoassimilados no alongamento das hastes. Nesse período há uma elevada taxa de mortalidade de perfilhos novos sombreados, devido à incapacidade dos mesmos de manterem o balanço interno de carbono, seja pela assimilação direta ou pela importação de fotoassimilados dos perfilhos maiores.

A produção econômica das culturas depende, dentre outros fatores, da translocação de fotoassimilados das folhas para as partes de interesse comercial da planta. As mudanças no índice de colheita têm sido responsáveis, em grande parte, pelo aumento do potencial de produção de alguns dos principais cereais cultivados no mundo (Austin et al., 1980; Perry \& D'Antuono, 1989). Apesar disso, pouco se sabe sobre as mudanças fisiológicas envolvidas. Gent \& Kiyomoto (1989) mostraram que as mudanças no índice de colheita em trigo (Triticum aestivun L.) podem ser atribuídas à: maior partição de nutrientes para a produção de grãos e retenção de uma maior porção dos fotoassimilidos fixados durante o enchimento. Em soja (Glycine max (L.) Merr.) foi observado que há uma correlação positiva entre tempo de enchimento dos grãos e produção (Egli et al., 1984; Boerma \& Ashley, 1988).

Vários estudos mostram que as plantas apresentam mecanismos de controle da partição de nutrientes em resposta a estímulos do meio, de forma a restabelecer o equilíbrio entre o crescimento de diferentes órgãos e entre o suprimento e a demanda de carboidratos.

O efeito da disponibilidade de nutrientes minerais sobre a partição de carboidratos depende do mineral que se encontra em níveis limitantes. Alguns trabalhos mostram que a baixa 
disponibilidade de N, P e S favorece o crescimento do sistema radicular, enquanto que níveis deficientes de $\mathrm{K}, \mathrm{Mg}$ e $\mathrm{Mn}$ determinam o efeito contrário. $\mathrm{O} \mathrm{Ca}, \mathrm{Fe}$ e $\mathrm{Zn}$ praticamente não apresentam efeito sobre a partição de carboidratos (Ericsson, 1995; McDonald et al., 1996).

Ericsson (1995) concluiu que os efeitos dos níveis de nutrientes minerais sobre a partição de carboidratos na planta podem ser explicados pelo balanço interno entre $\mathrm{N}$ e $\mathrm{C}$ no sistema radicular e na parte aérea (modelo de Thornley). No entanto, Marschner et al. (1996) afirmam que a ciclagem interna de nutrientes na planta altera os padrões de resposta previstos pelo modelo de Thornley.

Um trabalho desenvolvido por Engels (1994), onde o efeito da temperatura sobre o desenvolvimento de milho (Zea mays L.) e trigo foi estudado, mostra que para essas espécies o equilíbrio entre a atividade da parte aérea e a da raiz é obtido através de mudanças na atividade específica de cada órgão.

No entanto, os resultados obtidos por Nijs \& Impens (1997) com azevém sugerem que o princípio do equilíbrio funcional é válido em algumas condições, porém não é universal. Nesse experimento, o azevém alterou o padrão de partição de carboidratos em resposta à temperatura a fim de atingir o equilíbrio, porém não houve resposta nesse sentido quando o nível de $\mathrm{CO}_{2}$ foi alterado. Além disso, DeLucia et al. (1992) observaram que a relação raiz : parte aérea era máxima para Andropogon gerardii Vitman. quando a temperatura do solo era mantida a $25^{\circ} \mathrm{C}$. Os autores acreditam que temperaturas muito baixas sejam limitantes ao crescimento do sistema radicular dessa gramínea, o que explicaria o aumento da relação raiz : parte aérea até $25^{\circ} \mathrm{C}$, contrariando o que seria esperado de acordo com o modelo do equilíbrio funcional. Acima de $25^{\circ}$ C, no entanto, a redução da relação raiz : parte aérea pode ser explicada pelo aumento da atividade do sistema radicular, conforme previsto pelo modelo de equilíbrio funcional.

No caso das pastagens, há um interesse em se maximizar a produção de parte aérea, principalmente de folhas.

A tendência de manter um equilíbrio entre o crescimento de diferentes órgãos e entre o suprimento e a demanda de carboidratos apresentada pela planta pode ser limitante a alterações na relação raiz : parte aérea. Em trevo branco (Trifolium repens L.), por exemplo, foi observado que o crescimento do sistema radicular e da parte aérea são altamente correlacionados, sendo que quando esse balanço é quebrado através de desfolha ou deficiência hídrica, a planta responde rapidamente no sentido de retornar ao equilíbrio original. Esses resultados sugerem que o aumento 
da produção de trevo branco só pode ser obtido se o crescimento radicular também for incentivado (Blaikie \& Mason, 1990).

Apesar da seleção para maiores índices de colheita determinar aumentos na produção, deve haver um limite máximo para a manipulação desse parâmetro (Gifford et al., 1984). O aumento de parte aérea em detrimento do sistema radicular, por exemplo, é limitado pela necessidade de água e nutrientes da planta (são absorvidos pelo sistema radicular). Desta forma, a redução acentuada do crescimento do sistema radicular deve ser acompanhada por um aumento na sua atividade. No entanto, o aumento da atividade do sistema radicular pode acarretar um aumento nos gastos de carboidratos para sua manutenção, eliminando a vantagem obtida pela menor locação de carboidratos para o crescimento radicular. Além disso, a redução do sistema radicular com o concomitante aumento da sua atividade só é interessante em áreas de elevada fertilidade, pois o volume de solo explorado é reduzido.

As alterações na relação folha : haste também devem ser analisadas com cuidado. Uma redução acentuada na proporção de hastes da parte aérea pode prejudicar a penetração de luz no interior do dossel, limitando o potencial fotossintético da cultura. Uma alternativa seria alterar a arquitetura foliar como um todo, buscando folhas menores no topo e maiores na base ou uma distribuição em roseta. De qualquer forma, há um limite para a redução do tamanho das hastes, a partir do qual o ganho em termos de qualidade de forragem não compensa as perdas em produtividade devido à redução da taxa fotossintética.

Outro aspecto importante da produção vegetal, que depende da partição de carboidratos na planta, é o potencial de competição das espécies por fatores de crescimento. Em ambientes de alta fertilidade, geralmente ocorre competição por luz. Neste caso, são favorecidas as plantas que conseguem alterar a partição interna de carboidratos favorecendo a parte aérea. Segundo Aerts (1999), esses ambientes são, normalmente, dominados por espécies perenes de elevado ritmo de crescimento, distribuição vertical de folhas relativamente uniforme e estatura alta. Além disso, essas espécies apresentam uma alta taxa de renovação de tecidos.

Olff (1992) avaliou o efeito da luminosidade e nível de nutrientes sobre o desenvolvimento de seis espécies forrageiras. A análise da variância mostrou efeito significativo da luminosidade, do nível de nutrientes, da espécie e das interações entre esses fatores sobre as porcentagens de folhas, hastes e raízes e a área foliar específica. Os resultados mostram que 53,4\%, 60\% e 49\% da variância total na porcentagem de folhas, raízes e na área foliar específica, respectivamente, 
pode ser explicada pela intensidade luminosa. Baixa luminosidade e elevado nível de nutrientes favoreceu a produção de folhas, enquanto alta luminosidade e baixo nível de nutrientes a de raízes. A área foliar específica foi maior nas condições de baixa luminosidade, porém a capacidade de adaptação variou entre as espécies. O pequeno efeito da luminosidade sobre a porcentagem de hastes $(10,4 \%)$ talvez seja decorrente do fato da qualidade espectral da luz não ter sido alterada. Esses resultados mostram a importância da intensidade luminosa sobre a partição de carboidratos das plantas.

Em condições naturais, o sombreamento por plantas vizinhas determina uma redução na relação entre os comprimentos de onda vermelho e vermelho longo. Essa alteração na qualidade da luz incidente desencadeia uma série de mecanismos de adaptação à sombra: maior alongamento das hastes (estiolamento), menor relação folha : haste e raiz : parte aérea (Taiz \& Zeiger, 1991; Lemaire \& Millard, 1999). Casper et al. (1998), por exemplo, trabalhando com Abutilon theophrasti Medic., observaram que a relação folha : haste foi menor nas áreas de maior densidade populacional.

Em ambientes de baixa fertilidade a competição é principalmente por nutrientes minerais. Nesse caso, duas estratégias de competição são propostas por Aerts (1999): aumento da área de solo explorada pelo sistema radicular (maior alocação de carboidratos para as raízes e formação de raízes mais longas e finas) ou redução das perdas de nutrientes (baixa concentração de nutrientes nas plantas, baixa taxa de renovação de tecidos e elevada eficiência de reutilização de nutrientes). Em ambos os casos, a capacidade da planta de alterar o padrão de partição de carboidratos exerce um papel fundamental sobre sua resposta, interferindo com seu potencial competitivo.

As plantas apresentam mecanismos de adaptação (potencial genético de responder a uma determinada situação de estresse) e/ou aclimatação (resposta da planta a uma situação de estresse que reduz os efeitos por ele causados). Geralmente, os mecanismos de aclimatação determinam uma alteração no padrão de distribuição de carboidratos da planta de modo a minimizar os efeitos do estresse. Schulz (1994), por exemplo, observou em Pisum sativum L. um aumento no aporte de carboidratos para células da raiz em resposta à uma redução do potencial hídrico do solo. Através desse mecanismo de osmorregulação, a planta conseguiu reduzir, a curto prazo, os efeitos indesejáveis do baixo potencial hídrico do solo. 
Outro mecanismo de adaptação das plantas ao estresse hídrico observado em trigo é o aumento do sistema radicular em detrimento das folhas. A resposta antagônica entre desenvolvimento do sistema radicular e da parte aérea ajuda a planta a enfrentar a situação de estresse hídrico, reduzindo a área foliar (reduz a superfície de transpiração) e aumentando a área de exploração do sistema radicular (aumenta a absorção de água) (Kalapos et al., 1996).

Os mecanismos de resposta ao estresse podem estar ligados à expressão de genes específicos e ao controle hormonal (Geiger et al., 1996)

Em um experimento utilizando fluoridone (substância capaz de reduzir a síntese interna de ácido abscísico - ABA), foi determinado que o acúmulo de ABA desempenha um papel fundamental na manutenção do crescimento do sistema radicular e na inibição do desenvolvimento da parte aérea do milho (Saab et al., 1990).

Uma das principais características das plantas forrageiras é a capacidade de sobreviver e crescer em ambientes onde se encontram sujeitas a desfolhas constantes. A resistência ao pastejo pode ser decorrente de mecanismos de "fuga" (aqueles que reduzem a probabilidade e/ou intensidade do pastejo) ou "tolerância" (aqueles que aceleram a rebrota da planta). Os mecanismos de "fuga" envolvem mudanças morfológicas ou a produção de compostos bioquímicos e os mecanismos de "tolerância" estão ligados à posição dos meristemas e a processos fisiológicos (Briske, 1996). A maioria desses mecanismos depende, de forma direta ou indireta, de uma reprogramação da partição de carboidratos na planta. Para que haja a produção de compostos que evitem o pastejo, por exemplo, a planta têm que ativar rotas metabólicas que demandam carboidratos.

No caso de pastagens, as plantas de maior interesse são aquelas que apresentam mecanismos de tolerância ao pastejo, sendo os processos fisiológicos envolvidos dependentes, em grande parte, da partição de nutrientes na planta. Dyer et al. (1991) trabalhando com duas variedades de Panicum coloratum L. observaram que a variedade mais adaptada ao pastejo: produziu e armazenou mais carboidratos nas folhas; armazenou menos carboidratos nas hastes; apresentou maior atividade no floema; e enviou mais carboidratos para as raízes, sendo este o principal órgão de reserva. Segundo esses autores, os resultados sugerem que o armazenamento de carboidratos em formas prontamente disponíveis para o uso após a desfolha é um importante mecanismo de adaptação ao pastejo. Essa reserva, no entanto, deve ser feita em órgãos pouco acessíveis aos animais. 
O estudo da partição de nutrientes na planta forrageira também é importante para a determinação de seu manejo. Fatores como a transição das folhas de dreno para fonte; padrão de distribuição dos carboidratos das fontes para os drenos; localização dos órgãos preferenciais de reserva; velocidade de translocação dos carboidratos e, conseqüentemente, da produção de tecidos e da formação de reservas; etc, devem ser considerados na determinação da freqüência, intensidade e época (com relação ao estádio de desenvolvimento e condições ambientais) de pastejo.

Fulkerson \& Slack (1995) observaram que, no início da rebrota do azevém, as folhas eram o dreno preferencial de carboidratos, porém, após a expansão da primeira folha, o dreno principal passou a ser a coroa. Em outro experimento, os mesmos autores determinaram que desfolhas após o aparecimento de três folhas permitiam que o capim expressasse seu máximo potencial de produção no pastejo subsequente, pois esse intervalo era suficiente para que houvesse a total reposição das reservas de carboidratos da planta (Fulkerson \& Slack, 1994).

A rebrota da planta pode ser limitada pela disponibilidade de substratos (fonte) ou pelo número de pontos de crescimento (dreno). Nas situações onde a desfolha é severa, porém o meristema apical e as folhas em expansão são mantidos, a rebrota é controlada pela fonte de carboidratos. Schnyder \& Visser (1999) trabalhando com azevém concluíram que a rebrota foi controlada pela fonte. Nesse experimento o meristema apical e as folhas em expansão não foram eliminados, mas o crescimento nos primeiros dias após a desfolha foi $25 \%$ inferior ao de uma semana depois. Esse efeito foi atribuído à disponibilidade de substrato devido às baixas taxas de acúmulo de $\mathrm{C}$ e $\mathrm{N}$ e ao balanço negativo de carbono na área de rebrota.

Quando a desfolha elimina todas as folhas em expansão e o meristema apical, o número de pontos de crescimento é reduzido, e a rebrota passa a depender da ativação de gemas basais e laterais existentes na planta. Neste caso, a limitação está, provavelmente, ligada ao dreno metabólico e não ao fornecimento de substratos.

É notável a escassez de estudos com o objetivo de integrar conhecimentos sobre a partição de carboidratos e o manejo dos pastos, principalmente com plantas tropicais. A maior parte dos trabalhos que avaliam a resposta das plantas à herbivoria são feitos com insetos, o que dificulta a extrapolação dos resultados para áreas de pastagens. 


\subsection{Florescimento}

Geralmente, o estudo da fisiologia do florescimento visa o aumento da produção de flores (plantas ornamentais, etc) e de sementes (cereais, propagação, etc). No caso de gramíneas

forrageiras, no entanto, o principal objetivo é buscar meios de controlar (ou impedir) o florescimento, reduzindo o alongamento das hastes e, conseqüentemente, melhorando a qualidade da forragem. O aumento do florescimento, para essas espécies, seria importante apenas nos campos de produção de sementes.

O processo de florescimento pode ser dividido em quatro fases: indução; iniciação; formação e desenvolvimento floral. A indução corresponde aos eventos que sinalizam para a planta que ela deve alterar seu programa de desenvolvimento. A iniciação refere-se às alterações que ocorrem no meristema apical quando ele deixa de ser vegetativo e passa a ser reprodutivo. $\mathrm{O}$ período entre a formação do primórdio floral e a flor verdadeira corresponde à fase de formação, sendo que o desenvolvimento floral vai desde a formação até a antese. $O$ processo de florescimento só pode ser revertido até a fase de iniciação (Hopkins, 1995; Metzger, 1995).

A passagem da planta do estádio vegetativo para o reprodutivo depende de fatores genéticos, ambientais e hormonais que interagem entre si.

Dentre os fatores do ambiente que interferem no florescimento, os mais estudados são o fotoperíodo e a temperatura, sendo que diversas interações entre os mesmos são descritas na literatura.

A resposta das plantas ao comprimento do dia permite classificá-las em: plantas de dia longo, plantas de dia curto, plantas indiferentes, plantas intermediárias ou plantas anfofotoperiódicas. Esta classificação se baseia em um fotoperíodo crítico que depende da espécie em questão e não do comprimento absoluto do dia. As plantas que florescem quando o fotoperíodo é menor que o valor crítico, são consideradas de dia curto, e aquelas que florescem em resposta à comprimentos do dia acima do valor crítico, são classificadas como de dia longo. As plantas indiferentes florescem independentemente do fotoperíodo, enquanto as intermediárias só vão florescer quando submetidas à comprimentos de dia intermediários, ou seja, dias muito longos ou muitos curtos inibem o processo. O comportamento das plantas anfofotoperiódicas é o oposto das intermediárias, isso é, elas florescem quando o comprimento do dia é muito longo e/ou muito 
curto. Além das plantas que se encaixam nesta classificação, existem aquelas cuja indução depende de uma combinação entre dias curtos e longos (Taiz \& Zeiger, 1991; Hopkins, 1995).

As plantas de dias curtos ou de dias longos podem ainda ser classificadas como qualitativas ou quantitativas. Nas plantas qualitativas, o florescimento só ocorre se as exigências quanto ao fotoperíodo forem atendidas, entanto as quantitativas aceleram o processo de florescimento a partir de determinado comprimento do dia (Taiz \& Zeiger, 1991; Hopkins, 1995).

A forma como as mudanças no comprimento do dia são captadas pelas plantas, determinando uma mudança no seu desenvolvimento, ainda é fruto de muita discussão. A percepção de mudanças no fotoperíodo exige um pigmento que absorva a luz e se torne fotoquimicamente ativo. A maior parte das respostas fotomorfogênicas das plantas superiores parece depender do controle de um dos seguintes fotoreceptores: fitocromo, que absorve luz nas regiões do vermelho e do vermelho longo; um receptor de luz azul e de UV-A; e um receptor de UV-B. Esses dois últimos ainda não foram identificados (Hopkins, 1995).

O fitocromo pode ser encontrado em duas formas: uma que absorve luz vermelha $(\mathrm{Pv})$ e uma que absorve luz vermelha longa ( $\mathrm{Pvl})$. Além disso, ele é um pigmento fotocrômico, ou seja, a absorção de luz altera o seu espectro de absorção. A absorção de luz vermelha pela Pv faz com que ele se transforme em Pvl e vice-versa. Atualmente, acredita-se que o fitocromo seja inicialmente sintetizado na forma $\mathrm{Pv}$ e que só a forma Pvl seja fisiologicamente ativa. Além disso, a forma Pvl parece ser bastante instável, pois, mesmo que não seja reconvertido em Pv, sua concentração diminui rapidamente, determinando uma redução na quantidade total de fitocromo (Hopkins, 1995).

A temperatura, na maioria dos casos, determina mudanças no fotoperíodo crítico e há uma interação entre esses dois fatores na indução floral. Patterson et al. (1986) observaram que fotoperíodos curtos associados a temperaturas intermediárias $\left(27 / 21^{\circ} \mathrm{C}\right)$ aceleravam o florescimento em Panicum texanum Buckl. e Panicum miliaceum L.. Resultados com sorgo (Sorghum bicolor (L.) Moench.) também têm mostrado que o florescimento depende do efeito conjunto de fotoperíodo e temperatura (Morgan et al., 1987).

Em algumas plantas, o florescimento depende qualitativa e quantitativamente da exposição a temperaturas baixas. Esse fenômeno é conhecido como vernalização (Hopkins, 1995). Além disso, parece haver uma interação entre características genéticas ou evolutivas e temperatura. Em um trabalho com gramíneas $\mathrm{C}_{4}$ do gênero Bouteloua foi observado que o 
florescimento era reduzido em $70 \%$ quando espécies adaptadas a climas quentes eram submetidas à temperaturas baixas, o que foi atribuído à redução da atividade fotossintética (Bowman \& Turner, 1993).

O efeito do estresse hídrico sobre o florescimento ainda é muito pouco conhecido, porém alguns trabalhos com sorgo mostram que períodos de restrição hídrica podem atrasar tanto a indução quanto a iniciação floral (Craufurd et al., 1993).

A fase de desenvolvimento da planta também parece interferir nas respostas ao fotoperíodo. Adams et al. (2001) classificou as fases de desenvolvimento em: fase juvenil insensível ao fotoperíodo; fase entre indução e iniciação floral, sensível ao fotoperíodo; fase de desenvolvimento floral sensível ao fotoperíodo; e fase de desenvolvimento floral insensível ao fotoperíodo.

Existem poucos trabalhos relacionados à fisiologia do florescimento com gramíneas forrageiras tropicais, sendo que a maior parte avaliou apenas o efeito da temperatura e do fotoperíodo.

O capim andropogon (Andropogon gayanus Kunth.) é uma planta de dia curto com fotoperíodo crítico de 12 a 14 horas. Ele apresenta uma fase de juvenilidade de aproximadamente 6 semanas, não tendo sido possível induzi-lo ao florescimento com dias curtos aos 28 dias de crescimento. A temperatura ótima para o florescimento desta espécie é de $25^{\circ} \mathrm{C}$, sendo que com $17^{\circ} \mathrm{C}$ ele é muito reduzido, parando em temperaturas menores que $16^{\circ} \mathrm{C}$ (Tompsett, 1976).

O gênero Brachiaria apresenta diversas respostas aos fatores climáticos. A Brachiaria mutica (Forssk.) Stapf. é uma planta de dia curto qualitativa, enquanto a Brachiaria brizantha (Hochst. ex Rich.) Stapf. e a Brachiaria decumbens Stapf. não respondem ao fotoperíodo. Já a Brachiaria ruziziensis R. Germ. \& C. Evrard. é uma planta de dia curto quantitativa (Dirven et al., 1979). Neste trabalho, a B. mutica não produziu inflorescência com fotoperíodo acima de 14 horas, sendo que seu florescimento foi acelerado quando se passou de 12 para 10 horas de fotoperíodo. A B. brizantha e a $B$. decumbens já apresentavam inflorescência com menos de cinco dias de crescimento e a B. ruziziensis, no fotoperíodo de 14 horas, apresentou as primeiras inflorescências com menos de 40 dias, sendo que, em fotoperíodos menores, a indução floral ocorreu antes (Dirven et al., 1979). 
O capim de Rhodes (Chloris gayanus Kunth.) foi considerados por Dirven et al. (1979) como uma planta de dias curtos quantitativa, pois a porcentagem de perfilhos florescidos aumentava quando o fotoperíodo passava de 14 para 10 horas.

O capim jaraguá (Hyparrhenia rufa (Ness.) Stapf.) é uma planta de dia curto com fotoperíodo crítico de 12 horas e 15 minutos (Agreda \& Cuany, 1962).

O capim elefante é uma planta de dia curto com fotoperíodo crítico entre 12 e 15 horas. Após a iniciação, no entanto, as inflorescências só completam seu desenvolvimento com fotoperíodos de 16 horas. Em algumas circunstâncias, altas temperaturas podem inibir as respostas desta espécie aos dias curtos (Ferraris, 1978; Havely, 1985). Essas características talvez expliquem a baixa produção de sementes viáveis de capim elefante nas condições do Brasil.

O Panicum maximum, em geral, é classificado como planta de dia curto. No caso do capim Colonião (Panicum maximum Jacq. cv. Colonião), o fotoperíodo crítico é de 12 a 14 horas, sendo que quanto menor o fotoperíodo mais precoce é o florescimento. São necessários, no mínimo, 10 dias curtos para que ocorra a indução floral (Felippe, 1978). O cultivar Gatton panic foi classificado como planta de dia curto quantitativa respondendo a fotoperíodos entre 12 e 14 horas (Hopkinson \& English, 1982).

O Panicum maximum apresenta uma fase de juvenilidade que depende do tipo de perfilho (Felippe, 1978; Felippe, 1979) . Felippe (1979) observou que o perfilho principal do capim Colonião precisa produzir cerca de cinco a sete folhas antes que a planta se torne receptiva à indução floral (fase juvenil) e que, no caso dos perfilhos laterais, esse número depende do nível de inserção. Além disso, no mínimo quatro folhas são produzidas antes que ocorra a iniciação floral e o surgimento das primeiras inflorescências.

Os mecanismos fisiológicos responsáveis pelas mudanças relacionadas ao florescimento ainda são pouco conhecidos. Certamente, alguns hormônios estão envolvidos neste processo, porém seu modo de ação, local de produção, receptores celulares e controle ainda não foram totalmente determinados.

Os resultados obtidos por Ockerby et al. (2001), trabalhando com sorgo, sugerem que o sinal para o início da fase reprodutiva se origina nas folhas novas em expansão e nos primórdios foliares. Neste experimento, os autores observaram que a remoção desta folhas levava as plantas a uma fase anterior do programa de desenvolvimento, atrasando o florescimento. 
As mudanças no estádio de desenvolvimento das plantas dependem da interação entre diversos hormônios, que vão agir no sentido de manter a juvenilidade ou determinar a passagem da planta para a fase reprodutiva. Acredita-se que os principais grupos de hormônios conhecidos atualmente interfiram no processo de florescimento: auxinas; citoquininas; etileno; ácido abscísico; e giberelinas (Metzger, 1995).

O grupo das giberelinas é o mais conhecido, principalmente porque é através dele que se têm conseguido as melhores respostas em termos de manipulação do processo de florescimento.

As giberelinas são terpenóides formados por quatro unidades de isoprenóides (5 carbonos). Até o momento, já foram identificados mais de 84 tipos diferentes de giberelina, sendo que as espécies apresentam níveis de resposta diferentes a cada tipo. Em um trabalho onde foram comparados os efeitos de 9 tipos de giberelina sobre o florescimento em Lolium temulentum L., por exemplo, houve uma resposta maior para 12ß-OH-GA5 (Evans et al., 1990).

Em espécies que respondem a dias longos, a aplicação de giberelina aumenta o florescimento quando a planta é mantida sob condições de dias curtos, porém o efeito é pequeno quando ela é mantida sob dias longos. Esse efeito foi observado por King et al. (1993) com Lolium temulentum, que é uma planta de dias longos. Acredita-se que a planta não responda à aplicação de giberelina quando submetida a dias longos devido ao fato dos níveis endôgenos do hormônio já serem elevados nessas condições.

É importante lembrar que a indução floral só irá ocorrer se a planta tiver terminado a fase juvenil. Ainda não foi determinado o que faz com que a planta passe da fase juvenil para a fase reprodutiva, porém foi observado que este fenômeno está ligado a mudanças que ocorrem no ápice (Taiz \& Zeiger, 1991).

Apesar de ocorrerem simultaneamente, o florescimento e o alongamento das hastes parecem ser fenômenos independentes. Evans et al. (1990) observou que, em Lolium temulentum, a dose de giberelina necessária para induzir o florescimento era maior que para o alongamento das hastes e que alguns tipos de giberelinas interferiam em apenas um dos processos, enquanto outros influenciavam nos dois ou em nenhum deles. As diferentes respostas do florescimento e do alongamento das hastes parecem estar ligadas a grupos de giberelinas que apresentam as mesmas características de estrutura química.

Os reguladores de crescimento têm sido testados com o objetivo de inibir o florescimento e o alongamento das hastes em gramíneas forrageiras. Esses produtos podem ser divididos em 
duas categorias, de acordo com seu método de ação: inibidores do alongamento celular, e inibidores da divisão celular.

Marshall (1988) comparou o efeito de três desses produtos sobre o crescimento e florescimento em pastos onde predominava festuca (Festuca rubra L.). A hidrazida maléica (MH) e o mefluide (MEF), reduziram significativamente o crescimento e o florescimento, enquanto que o paclobutrazol (PAC) reduziu o crescimento, porém não afetou o florescimento.

A redução do florescimento devido à aplicação de produtos químicos, aumenta o valor alimentar da forragem. Roberts \& Moore (1990) observaram que a aplicação de amidaclor em festuca reduziu o florescimento, aumentou a digestibilidade in vitro da matéria seca e a porcentagem de proteína bruta e reduziu a porcentagem de componentes da parede celular.

A melhoria da qualidade nutricional, no entanto, pode vir acompanhada da redução da produtividade. Turner et al. (1990), utilizando mefluide em pastagens de festuca, obteve aumento de consumo de matéria seca na ordem de 50\% em 12 novilhas "Hereford". Porém, a disponibilidade de forragem foi reduzida de $4860 \mathrm{~kg} / \mathrm{ha}$ nas pastagens não tratada para 2398 $\mathrm{kg} / \mathrm{ha}$ nas áreas tratadas.

Em um experimento com capim Tanzânia, Penati et al. (2000) observaram que a aplicação de retardadores de crescimento alterou a relação folha : haste e a taxa de crescimento das plantas. No primeiro corte, não houve efeito significativo da aplicação de chlormequat, porém a relação folha : haste das plantas que receberam paclobutrazol foi maior que a das plantas controle, não havendo efeito deste regulador vegetal sobre a taxa de crescimento. No segundo corte, a relação folha : haste foi menor para as plantas que receberam chlormequat, não havendo efeito do paclobutrazol sobre esta variável. Ambos os retardadores de crescimento reduziram a taxa de crescimento do capim Tanzânia no segundo corte.

A redução da produtividade do pasto é um ponto limitante ao uso de produtos químicos para o controle do florescimento. Acredita-se que melhores resultados possam ser obtidos através de práticas de manejo específicas.

Alguns estudos com plantas temperadas utilizam informações sobre a fisiologia de florescimento e as taxas de nascimento e morte de perfilhos para programar cortes estratégicos com o objetivo de controlar o florescimento da planta forrageira, sem, contudo, comprometer a perenidade do pasto (Hume, 1991). 
A interrupção do desenvolvimento de perfilhos reprodutivos está ligada à época e intensidade da desfolha. Korte et al. (1984) e Korte et al. (1985) observaram que, em pastagens de azevém, a interrupção precoce do florescimento e pastejos pouco freqüentes aumentaram a sobrevivênica dos perfilhos reprodutivos. Resultados semelhantes foram obtidos por Hume (1991), ao comparar duas espécies de Lollium com Bromus willdenowii Kunth.. Korte et al. (1984) observaram também que a taxa de mortalidade dos perfilhos reprodutivos foi maior com alta intensidade de pastejo (80 a 86\%) do que com pastejos mais leves (25 a 24\%).

No caso de plantas tropicais cespitosas, como o capim Tanzânia, a eliminação tardia dos perfilhos reprodutivos através de pastejo pode ter conseqüências negativas. Nessas plantas, a colheita das hastes após o florescimento é difícil (alto grau de lignificação) e a qualidade da forragem se torna muito baixa.

O correto estabelecimento de práticas alternativas de manejo depende, no entanto, do conhecimento mais detalhado sobre a fisiologia de florescimento e o hábito de crescimento das plantas. Muitos detalhes a respeito do florescimento em gramíneas tropicais ainda precisam ser melhor elucidados, como: efeito de outros fatores ambientais (ex: disponibilidade de água) sobre o florescimento; interações entre os diversos fatores ambientais que interferem no florescimento; mecanismos hormonais e genéticos que determinam o florescimento e as interações entre eles e os fatores ambientais.

\subsection{Perfilhamento}

A capacidade de sobrevivência das plantas em sistemas de pastejo depende de fatores que dificultem a sua colheita (arquitetura da planta, compostos químicos que reduzam sua palatabilidade, etc) e/ou de mecanismos de tolerância. Esses últimos estão ligados ao número e origem de meristemas remanescentes após o pastejo e a processos fisiológicos que promovam o crescimento após a desfolha (Briske, 1996).

Segundo Colvill \& Marshall (1984), apesar das pastagens serem consideradas culturas perenes, os perfilhos geralmente apresentam um ciclo de vida limitado, ou seja, a persistência do pasto vai depender da capacidade da planta de repor os perfilhos mortos. É importante lembrar que a densidade populacional de perfilhos é fruto de um processo dinâmico de produção e morte, 
que ocorre ao longo do ano todo, porém em taxas diferentes (Colvill \& Marshall, 1984; Bullock, 1996).

Matthew et al. (2000) descrevem as metodologias que têm sido utilizadas para o estudo da densidade populacional de perfilhos em pastagens. Segundo os autores, o método mais simples seria contar regularmente o número de perfilhos por planta ou de uma área. Além disso, mudanças na densidade populacional de perfilhos podem ser explicadas em termos de natalidade e mortalidade se alguns perfilhos forem marcados e monitorados. Em estudos mais detalhados, a sobrevivência de perfilhos pertencentes a cada geração pode ser determinada marcando-se os perfilhos de cada geração em uma área fixa e monitorando-os por um tempo determinado. Para a análise demográfica completa, no entanto, além de acompanhar a sobrevivência de cada geração de perfilhos, seria necessário classificar os perfilhos novos de acordo com a geração que lhes deu origem.

O efeito do manejo sobre a densidade populacional de perfilhos foi bem estudado em pastagens temperadas. Jones et al. (1982) observaram que o número de perfilhos por área era maior sob pastejo contínuo que rotacionado em área exclusiva de azevém e Champman et al. (1983) encontraram o mesmo resultado trabalhando com pastagens de azevém consorciado. No pastejo contínuo, a densidade populacional de perfilhos tende a ser relativamente alta e constante ao longo do ano, enquanto em pastejo rotacionado o número de perfilhos atinge um pico na primavera e depois cai rapidamente durante a fase reprodutiva, mantendo-se mais ou menos estável no resto do ano (Hodgson, 1990).

Nos capins Tanzânia e Mombaça, submetidos a pastejo rotacionado, a densidade populacional de perfilhos também foi maior no final da primavera (novembro/dezembro) e menor durante a fase reprodutiva (abril/maio), mantendo-se relativamente constante nos demais meses do ano (Santos, 1997).

Vários estudos têm sido desenvolvidos para investigar o efeito do intervalo entre desfolhas sobre o perfilhamento, no entanto, os resultados ainda são inconsistentes. Em um experimento conduzido por Costa et al. (1992), a densidade populacional de perfilhos em Colonião e Tobiatã (Panicum maximum Jacq. cv. Tobiatã) não diferiu quando os cortes eram efetuados a cada $28 \mathrm{e}$ 35 dias, porém o aumento do intervalo entre desfolhas para 42 dias determinou uma redução no número de perfilhos por área. No experimento conduzido por Santos (1997), no entanto, não houve efeito de intervalo entre pastejos (28, 38 e 48 dias) sobre o número de perfilhos nos capins 
Tanzânia e Mombaça. Em um outro experimento desenvolvido por Herling et al. (1998), a densidade populacional de perfilhos foi influenciada apenas pelo nível de resíduo pós pastejo e pela época do ano, não havendo efeito significativo do período de descanso (35 e 42 dias).

Barbosa et al. (1996a), trabalhando com capim Mombaça, observaram que o aumento do intervalo entre cortes $(28,35,42$ e 49 dias de crescimento) reduziu o número de perfilhos remanescentes (maior número de perfilhos decapitados), mas aumentou o número de perfilhos novos. Para pastagens de Lollium perenne, Korte et al. (1985) concluíram que, sob condições favoráveis de umidade e disponibilidade de nutrientes, a densidade populacional de perfilhos é pouco afetada pela frequiência de pastejo, apesar dos efeitos sobre as taxas de natalidade e mortalidade serem significativos.

A inconsistência dos resultados obtidos nestes experimentos, provavelmente, pode ser atribuída a diferenças entre: as espécies ou cultivares; intervalos entre desfolhas testados; estádio de desenvolvimento do capim; e época do ano.

O efeito da severidade de pastejo sobre o perfilhamento, por outro lado, tem sido observado em vários estudos. Para azevém sob pastejo contínuo, foi observado que o maior número de perfilhos por área era obtido quando o pasto era mantido com 2 a $3 \mathrm{~cm}$. Acima desta altura, a densidade populacional era limitada pela competição entre os indivíduos e abaixo dela a mortalidade de perfilhos aumentava muito (Bircham \& Hodgson, 1983; Grant et al., 1983). Tallowin et al. (1989) determinaram que em áreas de azevém mantidas a 7,5 cm através de pastejo contínuo a produção de perfilhos era menor que em áreas a $3,5 \mathrm{~cm}$, sendo este fato o principal responsável pela menor densidade populacional de perfilhos no tratamento mais alto. Esses autores observaram também que a produção de perfilhos no pastejo mais suave parecia ser limitada pela inibição do desenvolvimento das gemas, uma vez que a taxa de aparecimento de folhas, e consequentemente de formação de gemas, não diferiu entre os tratamentos.

Para os capins Colonião, Mombaça, Tanzânia e Tobiatã, Coelho et al. (1999) observaram que não houve efeito da altura de corte sobre o número de perfilhos novos (tanto basais quanto aéreos), entretanto, o número de perfilhos decapitados foi maior e o número de perfilhos remanescentes (basais e aéreos) menor no pastejo mais baixo. Já Carvalho et al. (1999a) observaram que, inicialmente, o perfilhamento foi maior para os corte mais baixos nos capins Aruana (Panicum maximum Jacq. cv. Aruana), Mombaça e Tanzânia. Na fase final do 
experimento, no entanto, a taxa de mortalidade foi menor no tratamento mais alto, fazendo com que o número final de perfilhos fosse maior para este tratamento.

O efeito do nível de desfolha sobre o estímulo das gemas axilares pode ser decorrente da eliminação de dominância apical (Barbosa et al., 1996a; Richards et al., 1988) ou de mudanças no microclima da região das gemas através, por exemplo, de alterações na qualidade e quantidade de luz (Auda et al., 1966; Deregibus et al., 1985; Casal et al., 1990).

À medida que uma planta cresce, o auto-sombreamento faz com que as folhas em desenvolvimento recebam menores quantidades de luz azul e que a relação entre luz vermelha e vermelha longa fique mais estreita. Essas mudanças na qualidade da luz são revertidas após um corte ou pastejo. Para Brachiaria brizantha e Panicum maximum cv. Trichoglume foi observado que alta intensidade de luz estimulava o crescimento, perfilhamento, produção por perfilho e proporção de haste (Deinum et al., 1996). Santos et al. (1997) observaram que o sombreamento reduziu o perfilhamento em duas gramíneas do gênero Cyperus (o número médio de perfilhos diminui de 50 com $0 \%$ de sombreamento para 6 com $80 \%$ de sombreamento).

Fisher \& Dowdeswell (1995) conduziram um experimento com azevém para avaliar o efeito da rebrota e da manutenção de determinada altura do pasto sobre o perfilhamento. A área foi pastejada por carneiros a uma altura de $3 \mathrm{~cm}$ para se obter elevadas densidades populacionais de perfilhos. Após aproximadamente um mês, os animais foram retirados e quatro níveis de rebrota foram aplicados: até $6,9,12$ ou $15 \mathrm{~cm}$ de altura. Depois, as parcelas passaram a ser cortadas duas vezes por semana para manter uma altura de 6 ou $9 \mathrm{~cm}$. Os autores observaram que quando a rebrota atingia mais de $8,9 \mathrm{~cm}$ a densidade populacional de perfilhos caia e que as áreas mantidas a $6 \mathrm{~cm}$ apresentavam maior número de perfilhos do que aquelas mantidas a $9 \mathrm{~cm}$.

Os resultados de Tallowing et al. (1989) mostram que a intensidade de pastejo também interfere na demografia de perfilhos. Os autores observaram que a menor natalidade de perfilhos durante a primavera no tratamento mais leniente determinou diferenças na estrutura de classes de perfilhos que persistiram mesmo depois que as áreas passaram a ser pastejadas com mesma intensidade.

Alguns autores têm procurado classificar os perfilhos mortos a fim de investigar a causa da morte. Culvenor (1997) dividiu os perfilhos mortos em: perfilhos vegetativos pequenos; perfilhos vegetativos grandes; perfilhos pastejados a poucos centímetros $(2 \mathrm{a} 5 \mathrm{~cm}$ ) do meristema apical; perfilhos decapitados. A mortalidade de perfilhos, em plantas temperadas, parece estar 
ligada, principalmente, à severidade de pastejo (eliminação do meristema apical) e à competição dos perfilhos pequenos com os maiores (Covill \& Marshal, 1984; Culvenor, 1997).

O perfilhamento depende também de outros fatores como temperatura, nutrição mineral e espécie ou cultivar (Auda, 1966; George \& Reigh, 1987; Mazzanti et al., 1994).

Ferraris et al. (1986) observaram que houve uma interação entre os efeitos de temperatura e radiação solar no perfilhamento de capim elefante, sendo que a temperatura ótima para a produção de perfilhos dependeu do nível de radiação recebido. Em Panicum maximum cv. Trichoglume e Bachiaria brizantha o perfilhamento foi estimulado pelo aumento da intensidade de luz em um experimento conduzido em casa de vegetação com temperatura controlada (Deinum et al., 1996). King et al. (1995), comparando três espécies de festuca, observaram que o número de perfilhos por planta era maior com temperaturas de $17 / 13{ }^{\circ} \mathrm{C}$ (dia/noite) e que em apenas dois dos cinco cortes realizados houve interação entre os efeitos de espécie e temperatura.

Coughenour et al. (1985) observaram que o número de perfilhos em Hyparrhenia filipendula Stapf. dependeu do nível de nitrogênio aplicado e que houve uma compensação entre peso e número de perfilhos. O efeito positivo do nitrogênio sobre o densidade populacional de perfilhos têm sido observado para diversos cultivares de Panicum maximum (Alcântara et al., 1985; Barbosa et al., 1999; Zimmer et al.,1999; Tamassia et al., 1999).

Os resultados de Saarinen e Haansuu (2000), obtidos com Carex rostrata Stokes., sugerem que o balanço interno de $\mathrm{C}: \mathrm{N}$ desempenha um papel importante sobre o perfilhamento. Nesse experimento, plantas com elevada disponibilidade de compostos nitrogenados em relação a carboidratos na parte aérea iniciaram o desenvolvimento de perfilhos novos.

A variação na densidade populacional de perfilhos é muito grande entre as espécies tropicais. Enquanto para Panicum maximum são relatados valores tão baixos quanto 110 perfilhos $/ \mathrm{m}^{2}$ (Santos, 1997), para Cynodon spp., Carvalho (2000) encontrou valores de até 16.000 perfilhos $/ \mathrm{m}^{2}$.

Algumas diferenças são encontradas também entre os cultivares de uma mesma espécie. Carvalho (2000), trabalhando com três cultivares de Cynodon spp., observou que a densidade populacional de perfilhos foi maior para o Tifton-85 que para a Florakirk e o Coastcross em todas as épocas do ano.

Além da dinâmica de perfilhamento ter efeito direto sobre a perenidade do pasto, sua produção será determinada pelo peso e número de perfilhos que o compõem (Nelson \& Zarrough, 
1981). Em um experimento com azevém, Korte et al. (1984) observaram que os perfilhos reprodutivos eram mais pesados que os vegetativos e que os perfilhos novos contribuíam mais para a produção no pastejo mais intenso que no pastejo mais leve. Em outro experimento com azevém, Korte et al. (1985) observaram que, apesar dos perfilhos reprodutivos representarem uma pequena proporção do número de perfilhos totais (21\%), eles foram responsáveis por $73 \%$ da produção, pois eram mais pesados. Ainda nesse experimento, os autores observaram que os perfilhos de uma geração nova levavam em média 77 dias (variação de 60 a 100 dias) para atingir o peso dos perfilhos da geração inicial.

Para o capim Tanzânia, Barbosa et al. (1996b) observaram que, na primavera, a maior parte dos perfilhos novos aparecia na primeira semana após o corte, enquanto nas demais épocas do ano o perfilhamento se estendia até à terceira semana. Os autores observaram também, que, na rebrota, havia maior porcentagem de perfilhos remanescentes que novos. No entanto, o peso dos perfilhos não foi avaliado, ou seja, não se sabe se os perfilhos mais tardios realmente contribuem para a produção do pasto nem a real participação de perfilhos novos e remanescentes na rebrota do capim. Em um experimento conduzido por Corsi (1984), onde o peso dos perfilhos foi avaliado, se observou que o aparecimento de perfilhos em Panicum maximum só era importante na primeira semana após o pastejo.

Herling et al. (1998) determinaram que o peso médio dos perfilhos no capim Mombaça sofreu influência da interação entre: período de descanso (35 e 42 dias) e resíduo pós pastejo (1.000, 2.000 e $3.000 \mathrm{~kg} \mathrm{MS} / \mathrm{ha})$; período de descanso e época do ano; e resíduo pós pastejo e época do ano. O mesmo efeito, no entanto, não foi observado por Herling et al. (1999), onde a oferta de forragem $(3,3 ; 4,1$; e 4,9\% do peso vivo animal) e o período de descanso (28 e 35 dias) não tiveram efeito sobre a densidade populacional de perfilho, o peso médio dos perfilhos e a porcentagem de eliminação de meristema apical do capim Mombaça. Nesse experimento, foi observado que o peso e número de perfilhos decresceram ao longo dos pastejos (entre dezembro de 1997 e setembro de 1998).

Em pastagens de gramíneas temperadas, tem sido observado que existe uma compensação entre peso e número de perfilhos, sendo que a produção se mantêm relativamente estável sob diferentes condições de manejo (Matthew et al., 1995). Quando esse equilíbrio é quebrado, a produção do pasto se reduz rapidamente, mostrando a necessidade de correções no manejo. Em um experimento conduzido por Grant et al. (1983) em áreas ocupadas predominantemente por 
azevém, alturas de pastejo menores que $2 \mathrm{~cm}$ determinaram um aumento na morte de perfilhos e uma progressiva substituição do azevém por outras espécies.

Essa relação entre peso e número de indivíduos, verificada nos mais diversos tipos de população, deu origem à lei do auto-desbaste, considerada por alguns como a principal lei da ecologia de plantas. De acordo com essa lei, quando se constrói um gráfico do logaritmo do peso versus o logaritmo do número de indivíduos de uma população se obtém uma reta com inclinação -3/2 (Weller, 1987; Weller, 1990; Lonsdale, 1990; Bullock, 1996). Ultimamente essa lei têm sido muito discutida e questionada. Diversos cientistas acreditam que a inclinação da reta é mais variável do que afirma a Lei do Auto-desbaste, que a formação de uma reta neste gráfico (log peso x log número) é uma exceção e não uma regra e que a inclinação da reta varia de acordo com aspectos da biologia da planta (Lonsdale, 1990; Matthew et al., 1995). Existe também muita controvérsia com relação à interpretação da lei (Osawa \& Sugita, 1989; Weller, 1990).

Trabalhos realizados por Gomide et al. (1979) e Favoretto et al. (1987) com Panicum maximum mostraram que o vigor de rebrota nessa espécie estava melhor correlacionado com o número de meristemas apicais remanescentes após o pastejo do que com o teor de carboidratos não estruturais na base do caule e/ou da parte subterrânea. Esses resultados levaram à idéia de que, no manejo de capim colonião, devia-se buscar a preservação do meristema apical. Corsi (1988), no entanto, alerta para as limitações dessa estratégia de manejo no caso de pastagens de alta produtividade, onde o alongamento das hastes e, consequentemente, do meristema apical facilita sua eliminação durante o pastejo. A elevação do meristema apical é decorrente do período do ano, do intervalo entre desfolhas, da altura de corte e da adubação (Gomide et al., 1979; George \& Reigh, 1987; Costa et al., 1992).

No caso de áreas de elevada produtividade, a fertilidade do solo e os altos níveis de adubação nitrogenada favorecem a elevação do meristema apical, tornando bastante difícil o manejo com base em sua preservação. Nestes casos, Corsi (1988) sugere que a capacidade de perfilhamento da planta forrageira seja explorada para se obter uma rápida recuperação da pastagem. 


\subsection{Uso de reserva de nitrogênio}

A importância das reservas orgânicas para a rebrota de plantas forrageira é reconhecida desde o início do século XX (Davies, 1965). A partir de então, vários estudos foram desenvolvidos procurando-se usar informações sobre a reserva de carboidratos para a determinação do manejo de pastagens (Fulkerson \& Slack, 1994).

Estudos recentes envolvendo isótopos estáveis, no entanto, têm demostrado que a reserva de nitrogênio desempenha um papel tão ou mais importante quanto a de carboidratos na rebrota inicial das plantas forrageiras. Ourry et al. (1994) encontraram, em alfafa (Medicago sativa L.), correlação do nível de nitrogênio disponível nas raízes e coroas no início da rebrota com: a quantidade de $\mathrm{N}$ mobilizada para tecidos novos; a quantidade de $\mathrm{N}$ absorvida durante a rebrota; e a massa seca da parte aérea após 24 dias de rebrota. Nenhuma correlação desse tipo foi observada nas plantas com diferentes níveis iniciais de carboidratos nas raízes e coroas. Avice et al. (1996), também trabalhando com alfafa, observaram que um total de $73 \%$ do carbono e $34 \%$ do nitrogênio encontrado em órgãos de reserva foram mobilizados nos primeiros 30 dias de rebrota, sendo que, enquanto todo o nitrogênio foi recuperado nos tecidos em crescimento, a maior parte do carbono foi perdido através de respiração $(61 \%$ perdido pela respiração do sistema radicular; $8 \%$ pela respiração da parte aérea; e 5\% recuperado nos tecidos novos). A porcentagem de nitrogênio proveniente de reserva na parte aérea foi de 87, 66 e 52\% após 3, 10 e 30 dias de rebrota, respectivamente. A análise isotópica das diferentes frações químicas do tecido vegetal mostrou que entre 14 e 58\% do carbono da parte aérea proveniente de órgãos de reserva estava ligado à mobilização de compostos nitrogenados e não de carboidratos.

Schnyder \& Visser (1999) observaram que, em plantas de azevém submetidas à desfolha, a rebrota estava associada à: redução no nível de carboidratos solúveis e diluição da biomassa estrutural nas áreas imaturas de folhas em expansão; rápida transição para o crescimento dependente de assimilação corrente; rápido restabelecimento do balanço entre C:N. Segundo os autores, as reservas nitrogenadas foram a fonte predominante de $\mathrm{N}$ nos três primeiros dias de rebrota e $60 \%$ do fluxo líquido de reservas de carbono foi constituído de amino-C. Neste experimento, a reserva de carboidratos foi uma fonte insignificante de $\mathrm{C}$ para o crescimento dos perfilhos após o primeiro dia de rebrota. 
Segundo Lemaire \& Millard (1999), o armazenamento ocorre quando o C ou N podem ser remobilizados de um tecido e depois utilizados para o crescimento ou manutenção de outro. Os autores destacam ainda a existência de dois tipos de armazenamento: reciclagem e formação de reservas. A reciclagem é uma conseqüência da renovação de tecidos na planta (ex: reciclagem de proteínas durante a senescência foliar) e normalmente envolve um "estoque" metabolicamente ativo. Já a formação de reservas envolve a deposição de $\mathrm{N}$ ou $\mathrm{C}$ em organelas como vacúolos ou amiloplastos.

As reservas nitrogenadas podem ser utilizadas em diversas situações como para superar períodos curtos de deficiência de nitrogênio (Vouillot \& Devienne-Barret, 1999) e para garantir a rebrota após períodos de dormência e/ou inverno rigoroso (Thornton \& Bausenwein, 2000; Bausenwein et al. 2001a; Bausenwein et al., 2001b ) e após a desfolha (Ourry et al., 1994; Avice et al., 1996; Schnyder \& Visser, 1999)

$\mathrm{O}$ uso de reservas nitrogenadas nas plantas forrageiras depende de fatores ligados à espécie, ao ambiente e ao manejo.

Olff (1992), tentando correlacionar o padrão de partição de nitrogênio e matéria seca à capacidade competitiva das espécies, observou que a variabilidade é maior dentro da mesma espécie que entre espécies e concluiu que as diferenças em termos de partição de nutrientes entre espécies é pouco importante diante da plasticidade das plantas.

Outros estudos, no entanto, mostram diferenças claras entre espécies. Erley et al. (2000), observaram que o nível de fornecimento de $\mathrm{N}$ interferia no padrão de mobilização do nitrogênio de formas diferentes em festuca e azevém. Enquanto o azevém cessou a mobilização de $\mathrm{N}$ para perfilhos novos favorecendo o sistema radicular quando o suprimento de $\mathrm{N}$ foi reduzido, a festuca continuou enviando a maior parte do $\mathrm{N}$ mobilizado para os perfilhos novos. Thornton et al. (1993; 1994), comparando quatro espécies forrageiras (Lollium perenne, Poa trivialis L., Agrostis castellana Boiss. \& Reut. e Festuca rubra) observaram que todas utilizavam nitrogênio proveniente de reserva e de absorção radicular para a rebrota, sendo que a contribuição relativa de cada fonte dependia da espécie. Segundo os autores, os resultados obtidos sugerem que a importância relativa da mobilização de N para cada espécie esteja ligada à sua posição na ordem de sucessão em ambientes naturais.

Skinner et al. (1999) estudaram o efeito do nível de nitrogênio e de $\mathrm{CO}_{2}$ sobre a mobilização de $\mathrm{N}$ em alfafa, Pascopyrum smithii (Rydb.) A. Löve. (gramínea $\mathrm{C}_{3}$ ) e Bouteloua 
gracillis (Kunth.) Lag. ex Steud.(gramínea $\mathrm{C}_{4}$ ). Os autores observaram que a alfafa mobilizou maior porcentagem de suas reservas que as gramíneas e que, para todas as espécies, a mobilização de nitrogênio e a contribuição do $\mathrm{N}$ de reserva para o crescimento foram maiores quando o nível de $\mathrm{N}$ era alto e o nível de $\mathrm{CO}_{2}$ era compatível com o do ambiente.

Kim et al. (1991) observaram que a desfolha alterava o padrão de mobilização de nitrogênio em alfafa. Nas plantas intactas a haste e a raiz principal foram os principais drenos, enquanto que nas plantas submetidas à desfolha a maior parte das reservas nitrogenadas foram direcionadas para a rebrota da parte aérea.

$\mathrm{O}$ efeito da desfolha sobre a mobilização de nitrogênio vai depender de sua freqüência. Thornton \& Millard (1997) observaram que, tanto em azevém quanto em festuca, a freqüência entre desfolhas teve pouco efeito sobre a quantidade de nitrogênio proveniente de absorção radicular utilizada para o crescimento de folhas novas. No entanto, desfolhas mais freqüentes levaram à redução da capacidade de mobilização e, consequentemente, a uma menor taxa de crescimento das folhas novas.

Não foram encontrados trabalhos sobre o uso de reservas nitrogenadas no desenvolvimento de Panicum maximum. 


\section{MATERIAL E MÉTODOS}

\subsection{Experimento 1}

O presente experimento faz parte do Projeto Temático (Fapesp nº 98/0805-5) denominado "CAPIM" (Caracterização e Avaliação de Pastagens Irrigadas e seu Manejo) e foi conduzido na Fazenda Areão da ESALQ/USP, em Piracicaba-SP (22 42' S e 47³8’ W), no período de outubro de 1999 a junho de 2000. O clima da região, segundo a classificação de Köppen, é do tipo Cwa (tropical úmido, de três meses mais secos, junho, julho e agosto, e com chuvas durante o verão). O solo da área foi classificado como podzólico vermelho-escuro de textura média-argilosa. Durante o preparo do solo para o plantio, foi feita uma correção para se atingir $80 \%$ de saturação por bases, $5 \%$ de potássio na CTC e $30 \mathrm{mg} / \mathrm{dm}^{3}$ de fósforo.

A área total destinada ao projeto foi de 6,3 ha, sendo 1,1 ha utilizados como "área de apoio" para a manutenção dos animais necessários ao ajuste de lotação, e 5,2 ha cultivados com capim Tanzânia irrigado. Parte da área irrigada (0,4 ha) foi cercada para abrigar aparelhos utilizados para medições meteorológicas e o restante ( 4,8 ha) foi dividida em quatro blocos de aproximadamente 1,2 ha cada. Cada parcela experimental tinha 0,4 ha, subdividida em três piquetes de 0,13 ha a fim de facilitar o manejo dos pastos.

O capim Tanzânia foi plantado em março de 1999. Os dados de temperatura durante o período experimental podem ser vistos na Figura 1.

Durante o período experimental, a área foi irrigada através de um sistema de pivô central. O monitoramento do potencial de água no solo foi realizado através de 10 baterias de 6 tensiômetros instalados nas profundidades de 10,20, 40,60, 80 e $100 \mathrm{~cm}$. O potencial médio foi mantido em valores superiores a $-0,05 \mathrm{MPa}$, sendo as irrigação realizadas quando os tensiômetros instalados a $20 \mathrm{~cm}$ indicavam valores médios na faixa de $-0,3$ a $-0,4 \mathrm{Mpa}$. 


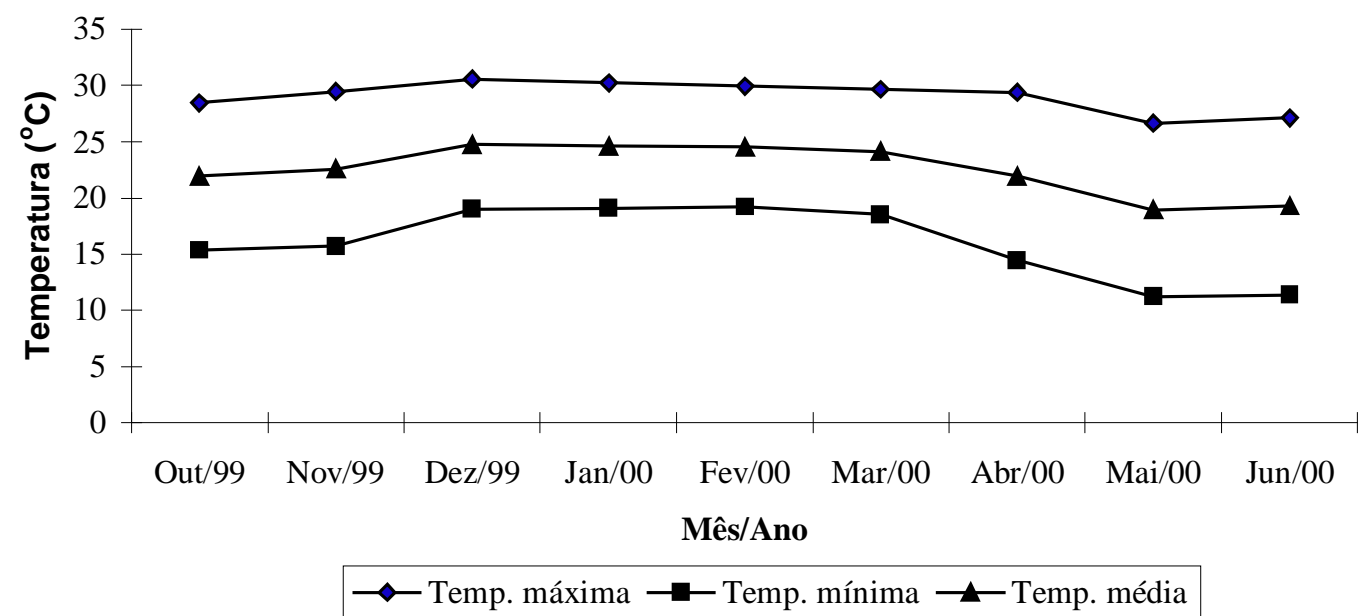

Figura 1 - Temperatura máxima, mínima e média mensal $\left({ }^{\circ} \mathrm{C}\right)$ de outubro de 1999 a junho de 2000 .

O delineamento experimental foi em blocos completos ao acaso com três tratamentos (intensidade de pastejo alta, média e baixa) e quatro repetições.

Os primeiros animais foram levados para a área experimental em agosto de 1999. Entre 17 de agosto e 21 de setembro foi feito um pastejo de uniformização, ficando todas as parcelas com aproximadamente $35 \mathrm{~cm}$ de altura de resíduo pós pastejo.

No período de 22 de setembro até 28 de outubro foi feito um pastejo para estabelecer os resíduos pré determinados para cada tratamento. O período experimental foi iniciado no dia 29 de outubro de 1999. Os blocos foram pastejados subseqüentemente por novilhos castrados da raça nelore, com peso médio inicial de $210 \mathrm{~kg}$. Durante o período experimental, as parcelas foram pastejadas em sistema rotacionado com 33 dias de descanso e 3 dias de ocupação. Após cada pastejo as áreas foram adubadas com $400 \mathrm{~kg} / \mathrm{ha}$ da fórmula 20-05-20.

A Tabela 1 mostra a data inicial dos ciclos de pastejo de cada bloco. 
Tabela 1. Data inicial dos ciclos de pastejo de cada bloco.

\begin{tabular}{ccccc}
\hline Ciclo de pastejo & \multicolumn{4}{c}{ Data inicial } \\
\hline & Bloco 1 & Bloco 2 & Bloco 3 & Bloco 4 \\
1 & $29 / 10 / 99$ & $07 / 11 / 99$ & $16 / 11 / 99$ & $25 / 11 / 99$ \\
2 & $04 / 12 / 99$ & $13 / 12 / 99$ & $22 / 12 / 99$ & $31 / 12 / 99$ \\
3 & $09 / 01 / 00$ & $18 / 01 / 00$ & $27 / 01 / 00$ & $05 / 02 / 00$ \\
4 & $14 / 02 / 00$ & $23 / 02 / 00$ & $03 / 03 / 00$ & $12 / 03 / 00$ \\
5 & $21 / 03 / 00$ & $30 / 03 / 00$ & $08 / 04 / 00$ & $17 / 04 / 00$ \\
6 & $26 / 04 / 00$ & $05 / 05 / 00$ & $14 / 05 / 00$ & $23 / 05 / 00$ \\
\hline
\end{tabular}

Os níveis de intensidade de pastejo foram obtidos através da variação da taxa de lotação animal e avaliados com base na massa de resíduo pós pastejo. O objetivo inicial era atingir 1.000; 2.500 e $4.000 \mathrm{~kg} \mathrm{MSV/ha} \mathrm{(matéria} \mathrm{seca} \mathrm{verde/ha)} \mathrm{pós} \mathrm{pastejo} \mathrm{para} \mathrm{os} \mathrm{tratamentos} \mathrm{de} \mathrm{alta,} \mathrm{média}$ e baixa intensidade de pastejo, respectivamente. A avaliação do resíduo pós pastejo foi feita por ${ }^{1}$ Penati (Tabela 2).

Tabela 2. Resíduo pós pastejo obtido durante o período experimental.

\begin{tabular}{|c|c|c|c|}
\hline \multirow[t]{3}{*}{ Época do ano } & \multicolumn{3}{|c|}{ Intensidade de pastejo } \\
\hline & Alta & Média & Baixa \\
\hline & \multicolumn{3}{|c|}{ Resíduo pós pastejo (kg MSV.ha ${ }^{-1}$ ) } \\
\hline Outubro/Fevereiro & $1277^{\mathrm{c}}$ & $2459^{b}$ & $3106^{\mathrm{a}}$ \\
\hline Fevereiro/Junho & $1763^{\mathrm{c}}$ & $3346^{\mathrm{b}}$ & $5335^{\mathrm{a}}$ \\
\hline
\end{tabular}

Obs: Médias seguidas da mesma letra na linha não diferem entre si $(\mathrm{P}>0,05)$.

Fonte: ${ }^{1}$ Penati.

${ }^{1}$ PENATI, M.A. Estudo do desempenho animal e produção do capim Tanzânia (Panicum maximum Jacq.) em um sistema rotacionado de pastejo sob irrigação em três níveis de resíduo pós pastejo. Piracicaba. Tese (Doutorado) - Escola Superior de Agricultura "Luiz de Queiroz", Universidade de São Paulo (em elaboração). 
Para avaliar o perfilhamento, foram delimitadas, inicialmente, 15 subamostras $(0,5 \times 1,0$ m) em cada parcela, sendo três subamostras marcadas a mais por motivos de segurança (caso ocorresse algum imprevisto e uma subamostra fosse perdida o experimento não seria prejudicado).

Antes do início do experimento, foi realizado um pré ensaio para se determinar como e quando deveria ser feita a marcação dos perfilhos. Na primeira etapa do pré ensaio, foram delimitadas algumas amostras e os perfilhos foram marcados de diversas formas com fios de arame coloridos. Foi observado que a melhor forma de marcação era contornar o perfilho com o arame e depois torcer uma ou duas vezes as pontas. Para reduzir o nível de perda, os arames deveriam ser colocados na base dos perfilhos. Observou-se também que os fios deveriam ser amarrados com uma certa folga para evitar que os perfilhos fossem "estrangulados" a medida que crescessem (Figura 2). Para escolher a melhor forma de amarrar os perfilhos foi observado o tempo de marcação, o nível de dano provocado no perfilho e a porcentagem de perda de arames após o pastejo.

Foto

Figura 2 - Forma de marcação dos perfilhos com fio de arame. 
$\mathrm{Na}$ segunda etapa do pré ensaio, foram delimitadas algumas amostras onde os perfilhos foram marcados 11, 22 e 33 dias após o pastejo. Observou-se que aos 11 dias após o pastejo foram marcados $64 \%$ dos perfilhos novos e que estes corresponderam a $80 \%$ da massa de forragem da amostra no dia da avaliação. Além disso, as marcações realizadas 22 e 33 dias após o pastejo alteraram acentuadamente a região ao redor das amostras, o que a médio prazo poderia modificar o ambiente de desenvolvimento dos perfilhos.

Desta forma, decidiu-se marcar os perfilhos sempre 11 dias após o pastejo. Nessa ocasião os perfilhos novos eram marcados com fios de arame colorido, sendo que a cada geração correspondia uma cor, e os arames dos perfilhos mortos eram recolhidos.

Foram marcados apenas os perfilhos basais que apresentavam mais de $10 \mathrm{~cm}$ de comprimento. Em algumas épocas, foi observada a formação de "rosetas" de pequenos perfilhos aéreos. Esses perfilhos não foram considerados, pois sua participação na produção total era relativamente pequena e a porcentagem de perda das marcações seria muito alta (remoção pelos animais).

O número de perfilhos mortos, normalmente, era determinado recolhendo-se todos os arames de perfilhos mortos e contando-os posteriormente, e o número de perfilhos remanescentes era calculado por diferença. Nos blocos onde choveu durante os dias de pastejo, muitos arames foram enterrados, o que aumentaria muito a porcentagem de perdas caso esta metodologia fosse mantida. Nestes casos, foram contados os perfilhos remanescentes e o número de perfilhos mortos foi calculado por diferença.

Os perfilhos vegetativos eram considerados mortos quando não se observava rebrota do mesmo no momento da marcação (11 dias após cada pastejo). No caso dos perfilhos reprodutivos, a separação entre perfilhos mortos e vivos foi mais subjetiva, pois, apesar de não apresentarem rebrota devido às alterações no meristema apical, muitos deles permaneciam contribuindo para a recuperação da planta por bastante tempo. Desta forma, considerou-se morto o perfilho que se apresentasse amarelecido ou com danos físicos severos.

Um dia antes de cada pastejo duas subamostras eram cortadas por parcela. Os perfilhos eram separados por geração, contados e pesados. Uma subamostra de cada geração era separada para a determinação do teor de matéria seca (estufa a 65oC até peso constante), da porcentagem de folhas e hastes e da digestibilidade "in vitro" da matéria orgânica. A digestibilidade foi determinada segundo o método de Tilley \& Terry (1963). 
A análise estatística foi realizada com o auxílio do pacote estatístico SAS (SAS, 1990). Os dados de cada geração de perfilhos foram analisados segundo um modelo de medidas repetidas no tempo. Foi feito o teste da esfericidade, através do procedimento GLM, a fim de se determinar a estrutura da matriz de variância e co-variância. Em seguida, foi feita a análise da variância através do procedimento MIXED. Nos casos em que o teste de esfericidade foi significativo $(\mathrm{P}<0,05)$, foi feita uma análise multivariada da variância e, nos casos em que o teste não foi significativo $(\mathrm{P}>0,05)$, optou-se pela estrutura univariada. $\mathrm{O}$ nível de significância adotado para a análise da variância foi de $15 \%$. Para os efeitos significativos, foi feito um teste de comparação de médias, através da opção LSMEANS do procedimento MIXED.

\subsection{Experimento 2}

O experimento foi desenvolvido no "Macaulay Land Use Research Institute", em Aberdeen - Escócia, entre julho e agosto de 2000.

Foram utilizados 25 vasos de $23 \mathrm{~cm}$ de diâmetro. A fim de melhorar a drenagem e evitar a perda de substrato foi colocado, no fundo dos vasos, um disco de tela "Tygan" (Bradley Lomas Electrolok Ltd, Eckington, Reino Unido), uma folha de papel de filtro Whatman № 1 e $1 \mathrm{~cm}$ de areia grossa (1 a $10 \mathrm{~mm}$ de diâmetro). O restante do espaço dos vasos foi preenchido com areia fina ( 0,25 a $0,7 \mathrm{~mm}$ de diâmetro). Após o preparo, o substrato foi "lavado" três vezes, através da adição de água deionizada, com o objetivo evitar contaminação.

O plantio do capim Tanzânia foi feito colocando-se 15 sementes por vaso. Após a semeadura, os vasos foram colocados em uma câmara de crescimento com ambiente controlado (Conviron, Winnipeg, Canadá) (Figura 3). A câmara foi mantida no escuro a $30^{\circ} \mathrm{C}$ e $90 \%$ de umidade por seis dias, até o início da germinação. Durante este período, a areia foi mantida úmida com água deionizada.

Após a germinação, a câmara de crescimento foi ajustada para um fotoperíodo de 12 horas, $500 \mu$ moles. $\mathrm{m}^{-2} \cdot \mathrm{s}^{-1}$ de radiação fotossinteticamente ativa na altura das plantas, e uma umidade relativa constante de $60 \%$. A temperatura foi mantida em $26^{\circ} \mathrm{C}$ durante o período escuro e $30^{\circ} \mathrm{C}$ no período claro. Duas semanas após a germinação, foi feito um desbaste, deixando-se três plantas por vaso. Durante a fase pré-experimental, os vasos receberam uma solução nutritiva 
completa até atingir a capacidade de campo, três vezes por semana. A solução nutritiva era idêntica à utilizada por Thornton et al. (1993), exceto pelo nitrogênio, cujo a concentração foi de 1,5 mol.m $\mathrm{m}^{-3} \mathrm{NH}_{4} \mathrm{NO}_{3}$.

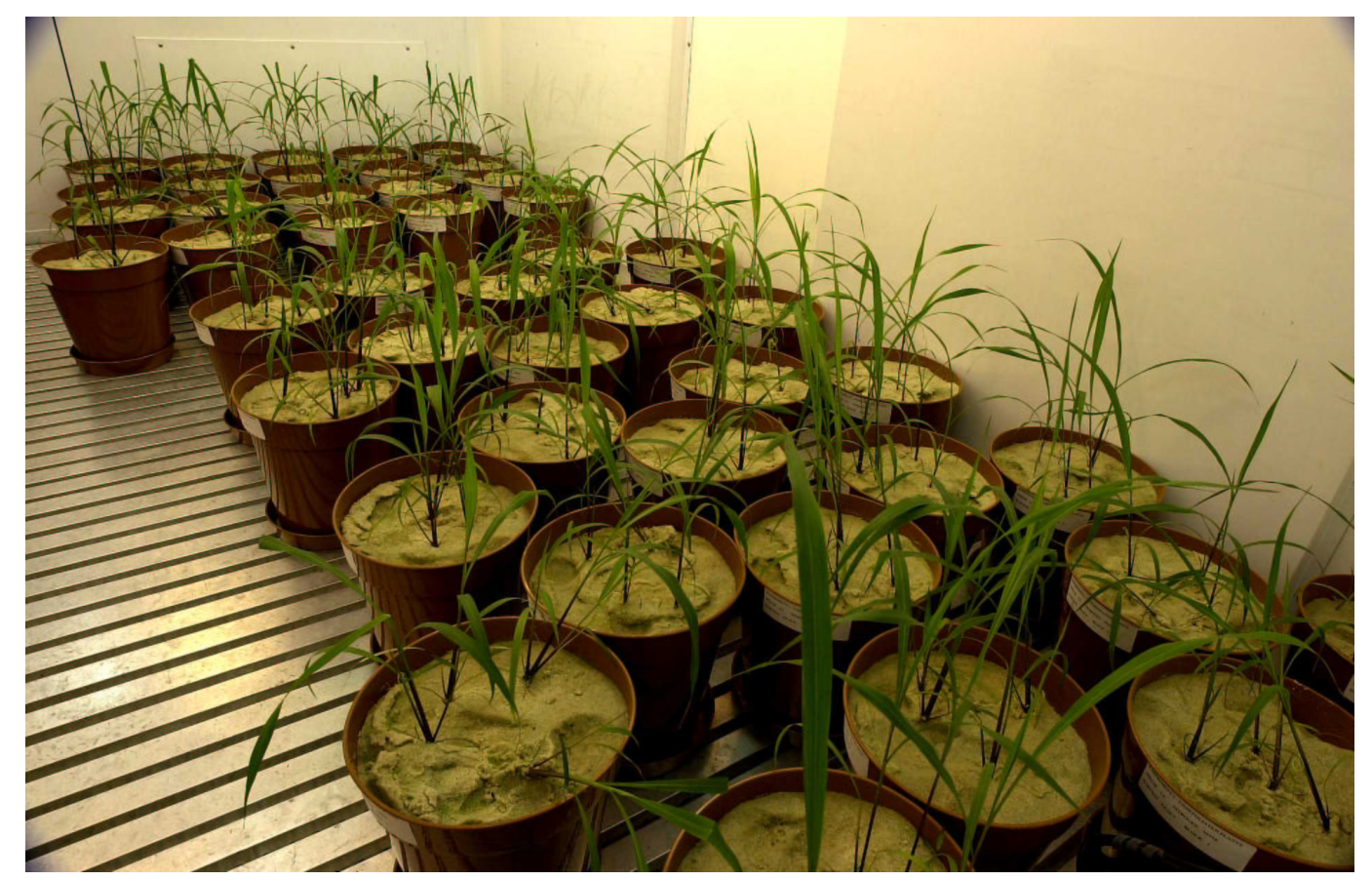

Figura 3 - Câmara de crescimento com vasos de capim Tanzânia.

A primeira folha produzida no perfilho foi considerada como folha um, a segunda como folha dois, etc. Fios de arame coloridos foram colocados em cada planta para facilitar a identificação das folhas. O comprimento das folha sete, oito e nove foi medido a cada dois dias para determinar o momento de sua completa expansão, usando-se a metodologia descrita por Davies (1993). As folhas foram consideradas expandidas quando apresentaram uma redução significativa na taxa de alongamento em mais de $50 \%$ das plantas recebendo nitrogênio. 
O delineamento experimental foi em blocos completos ao acaso. No momento em que a folha sete completou sua expansão, cinco vasos foram colhidos. Nos demais vasos, toda solução nutritiva foi "lavada" quatro vezes com 1,0 $\mathrm{dm}^{3}$ de água deionizada. Metade destes vasos recebeu quatro vezes $1,0 \mathrm{dm}^{3}$ de uma solução nutritiva semelhante à que vinha sendo utilizada, porém enriquecida com ${ }^{15} \mathrm{~N}$ de forma a apresentar 5,01 átomo-\% de abundância. De forma semelhante, a outra metade dos vasos recebeu uma solução nutritiva similar, porém sem nitrogênio. As plantas passaram então a receber a solução correspondente, enriquecida $\operatorname{com}^{15} \mathrm{~N}$ (tratamento $+\mathrm{N}$ ) ou sem $\mathrm{N}$ (tratamento Zero $\mathrm{N}$ ), três vezes por semana.

Novas coletas foram feitas quando as folhas oito e nove completaram sua expansão. Em cada ocasião, cinco vasos de cada tratamento $(+\mathrm{N}$ e Zero $\mathrm{N})$ foram colhidos.

No momento das coletas, a areia dos vasos era descartada e as raízes das plantas lavadas através de uma peneira de $1 \mathrm{~mm}$ com água deionizada, resultando em uma perda mínima de material. Depois, as plantas eram separadas em: raízes; perfilhos laterais; haste; folhas 1 a 3; folha 4; folha 5; folha 6; folha 7; folha 8; e folhas 9 a 13 (Figura 4). Foi considerado como haste a estrutura que permaneceu na base da parte aérea após a retirada de todas as folhas (as bainhas foram coletadas junto com as lâminas foliares). As partes das plantas foram secadas em estufa a $65^{\circ} \mathrm{C}$, pesadas e depois moídas em moinho de bolas (Retsch, Haan, Alemanha). As concentrações de $\mathrm{N}$ total e de ${ }^{15} \mathrm{~N}$ das amostras foram determinadas utilizando-se um espectrômetro de massa de fluxo contínuo TracerMAT (Finnigan MAT, Hemel Hempstead, Reino Unido).

Para os tratamentos $+\mathrm{N}$, o enriquecimento em ${ }^{15} \mathrm{~N}$ das amostras foi utilizado para calcular a absorção de nitrogênio a partir da solução nutritiva marcada com ${ }^{15} \mathrm{~N}$, utilizando-se as equações descritas por Millard e Nielsen (1989). A diferença entre o conteúdo de nitrogênio total e de nitrogênio marcado foi designada como nitrogênio não marcado, considerado como sendo o nitrogênio presente nas plantas no momento da primeira coleta. Para os tratamentos Zero N, o conteúdo de $\mathrm{N}$ não marcado era equivalente ao conteúdo de nitrogênio total. Qualquer aumento no conteúdo de $\mathrm{N}$ em uma parte da planta, ao longo das coletas, representava mobilização de 
nitrogênio vindo de outra parte da planta; da mesma forma, uma redução no conteúdo de nitrogênio representava saída de nitrogênio para outra parte da planta.

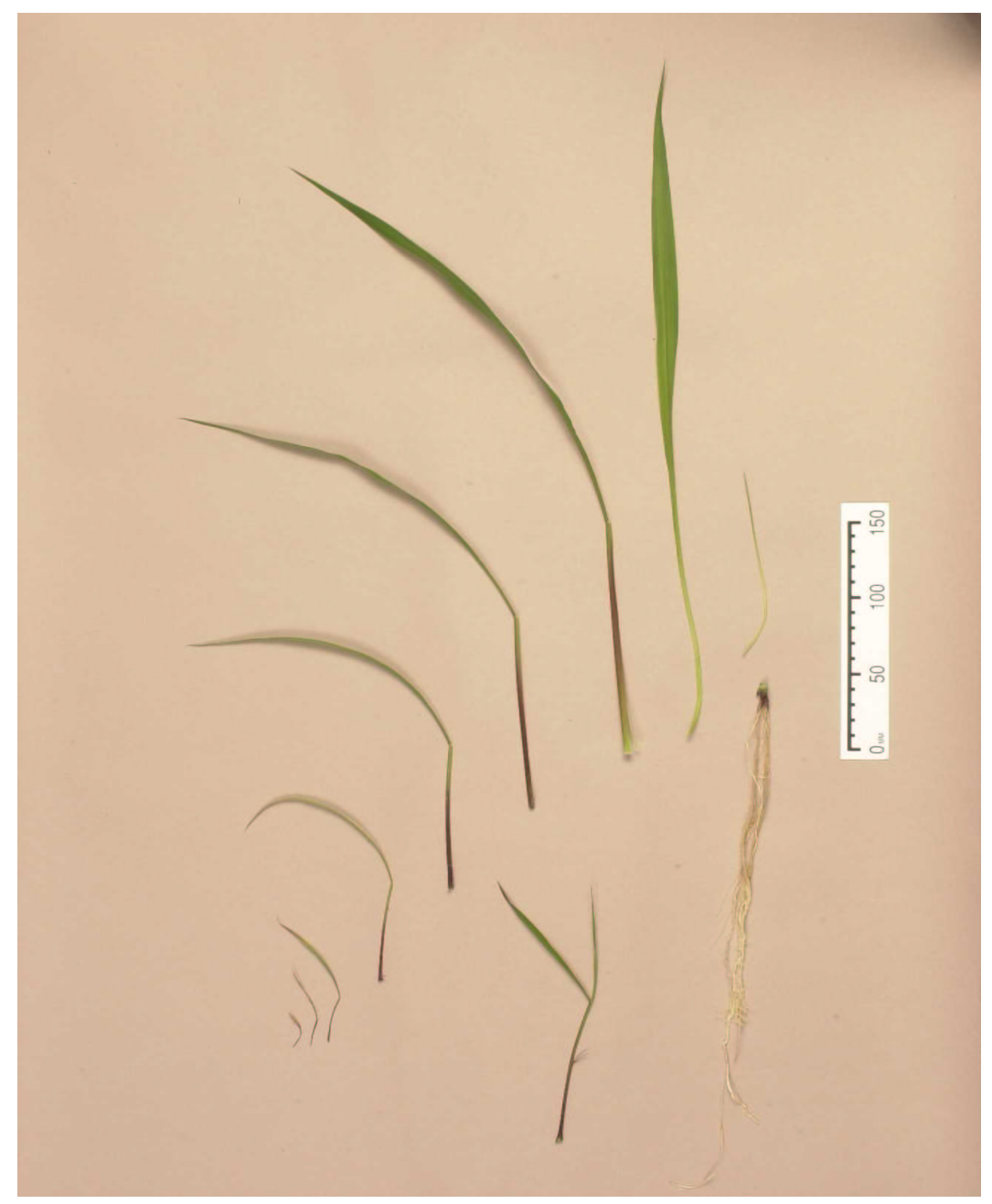

Figura 4 - Separação da planta de capim Tanzânia.

A análise estatística foi feita com o auxílio do pacote estatístico SAS (SAS, 1990). A análise da variância foi feita através do procedimento GLM e as médias dos tratamentos comparadas através de contrastes ortogonais utilizando-se o teste F. Os dados foram 
transformados antes da análise, sempre que as pressuposições do modelo foram violadas. Como a transformação não afetou a interpretação dos resultados, os dados originais serão apresentados. 


\section{RESULTADOS E DISCUSSÃO}

\subsection{Experimento 1}

A maior densidade populacional de perfilhos foi observada no ciclo 1. Nos demais ciclos foram mantidos, aproximadamente, 450 perfilhos. $\mathrm{m}^{-2}$, não havendo diferença entre os tratamentos (Tabela 3). Em experimento conduzido por Santos (1997), observou-se que a densidade populacional de perfilhos no capim Tanzânia era maior no final da primavera e menor no período do florescimento, mantendo-se constante no restante do ano. No presente experimento, também foi observada uma maior densidade de perfilhos no final da primavera (ciclo 1), porém não houve redução durante o período do florescimento (ciclos 4 e 5).

Tabela 3. Número total de perfilhos do capim Tanzânia submetido a três intensidades de pastejo ao longo dos ciclos (outubro/1999 a junho/2000).

\begin{tabular}{cc}
\hline Ciclo de pastejo & $\begin{array}{c}\text { Número de perfilhos } \\
\text { (perfilhos. }{ }^{-2} \text { ) }\end{array}$ \\
\hline 1 & $619^{\mathrm{A}}$ \\
2 & $457^{\mathrm{B}}$ \\
3 & $430^{\mathrm{B}}$ \\
4 & $452^{\mathrm{B}}$ \\
5 & $450^{\mathrm{B}}$ \\
6 & $448^{\mathrm{B}}$ \\
\hline
\end{tabular}

Obs: Médias seguidas pela mesma letra na coluna não diferem entre si $(\mathrm{P}>0,15)$. 
A literatura mostra que, de modo geral, a intensidade de pastejo interfere na densidade populacional de perfilhos. Para azevém sob pastejo contínuo, foi observado maior número de perfilhos por área quando o pasto era mantido com 2 a $3 \mathrm{~cm}$. Acima desta altura, a densidade populacional era limitada pela competição entre os indivíduos e abaixo dela a mortalidade de perfilhos aumentava muito (Bircham \& Hodgson, 1983; Grant et al., 1983). Tallowin et al. (1989) determinaram que em áreas de azevém mantidas a 7,5 cm de altura através de pastejo contínuo a produção de perfilhos era menor que em áreas a $3,5 \mathrm{~cm}$, sendo este fato o principal responsável pela menor densidade populacional de perfilhos nas áreas pastejadas a 7,5 cm. Para o capim Tanzânia, Coelho et al. (1999) não observaram efeito da altura de corte sobre o número de perfilhos novos, no entanto, o número de perfilhos remanescentes foi maior no tratamento mais alto. Já Carvalho et al. (1999a) observaram que, inicialmente, o número de perfilhos novos foi maior para as alturas de corte mais baixas, no entanto, na fase final do experimento, a taxa de mortalidade foi menor no tratamento mais alto, sendo a densidade populacional de perfilhos maior para este tratamento.

No presente experimento, não foi observado efeito significativo dos tratamentos sobre a densidade populacional de perfilhos. Este resultado pode ser decorrente do elevado nível de fertilidade do solo, que estimularia o aparecimento de novos perfilhos nas áreas onde a mortalidade foi mais elevada (Barbosa et al. 1998; Zimmer et al., 1999; Tamassia et al., 1999). Além disso, é possível que os níveis de intensidade de pastejo testados não tenham sido distantes o suficiente para provocar diferenças entre os tratamentos.

Para as gerações 1, 2, 3 e 4, a densidade populacional de perfilhos diminuiu ao longo das avaliações (Tabela 4). Houve efeito de tratamento apenas para as gerações 2 e 6 , sendo o número de perfilhos destas gerações maior nas áreas submetidas a baixa intensidade de pastejo e menor nas de alta intensidade de pastejo (Tabela 5). Para a geração 5 não houve efeito de tratamento e nem de período do ano. 
Tabela 4. Efeito do ciclo de pastejo sobre o número de perfilhos das quatro primeiras gerações do capim Tanzânia submetido a três intensidades de pastejo (alta, média e baixa).

\begin{tabular}{ccccc}
\hline Ciclo de pastejo & \multicolumn{4}{c}{ Número de perfilhos (perfilhos.m ${ }^{-2}$ ) } \\
\cline { 2 - 5 } & Geração 1 & Geração 2 & Geração 3 & Geração 4 \\
\hline 1 & $619^{\mathrm{A}}$ & - & & \\
2 & $280^{\mathrm{B}}$ & $177^{\mathrm{A}}$ & - & \\
3 & $165^{\mathrm{C}}$ & $107^{\mathrm{B}}$ & $159^{\mathrm{A}}$ & - \\
4 & $116^{\mathrm{D}}$ & $65^{\mathrm{C}}$ & $114^{\mathrm{B}}$ & $158^{\mathrm{A}}$ \\
5 & $87^{\mathrm{E}}$ & $60^{\mathrm{C}}$ & $76^{\mathrm{C}}$ & $123^{\mathrm{B}}$ \\
6 & $60^{\mathrm{E}}$ & $34^{\mathrm{C}}$ & $45^{\mathrm{D}}$ & $91^{\mathrm{C}}$ \\
\hline
\end{tabular}

Obs: Médias seguidas pela mesma letra na coluna não diferem entre si $(\mathrm{P}>0,15)$.

Tabela 5. Efeito intensidade de pastejo sobre o número de perfilhos da segunda e sexta geração do capim Tanzânia.

\begin{tabular}{ccc}
\hline Intensidade de pastejo & \multicolumn{2}{c}{ Número de perfilhos (perfilhos.m ${ }^{-2}$ ) } \\
\cline { 2 - 3 } & Geração 2 & Geração 6 \\
\hline Alta & $64^{\mathrm{c}}$ & $120^{\mathrm{b}}$ \\
Média & $93^{\mathrm{b}}$ & $139^{\mathrm{ab}}$ \\
Baixa & $109^{\mathrm{a}}$ & $153^{\mathrm{a}}$ \\
\hline
\end{tabular}

$\overline{\text { Obs: Médias seguidas pela mesma letra na coluna não diferem entre }}$ si $(\mathrm{P}>0,15)$.

A Figura 5 mostra o efeito da intensidade de pastejo sobre a proporção de cada geração no número total de perfilhos do capim Tanzânia nos ciclos 4, 5 e 6. É possível observar que a renovação da população de perfilhos foi maior nas áreas submetidas a alta intensidade de pastejo. No ciclo 4, os perfilhos com mais de 100 dias (geração 1) representavam apenas $17 \%$ do total nos locais submetidos a pastejo mais intenso, enquanto que, nos tratamentos de intensidade de pastejo média e baixa, representavam 20 e 34\%, respectivamente. Este mesmo padrão é observado para os ciclos 5 (gerações 1 e 2) e 6 (gerações 1,2 e 3 ). 

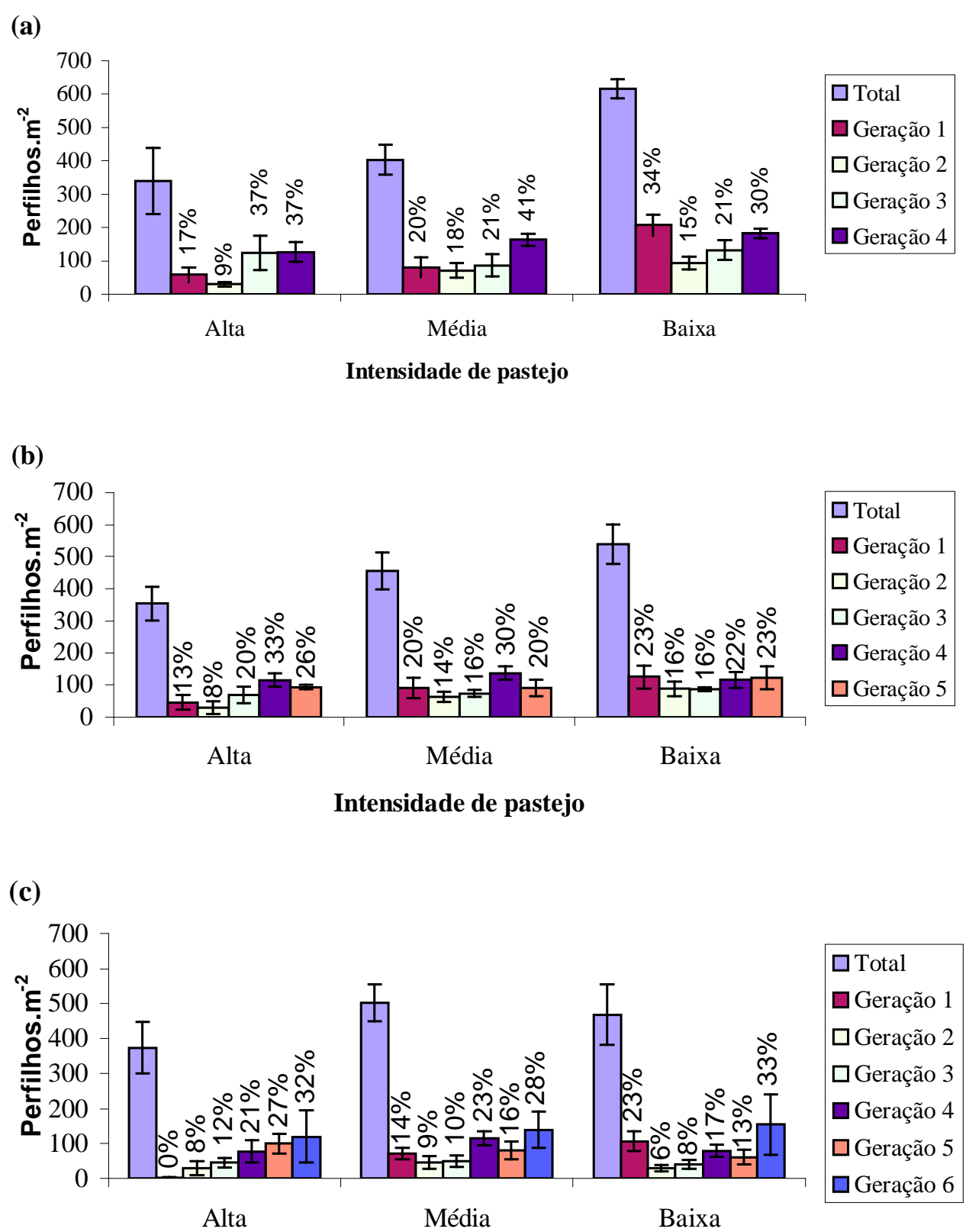

Intensidade de pastejo

Figura 5 - Efeito da intensidade de pastejo sobre a participação das gerações no número total de perfilhos do capim Tanzânia no: (a) ciclo 4; (b) ciclo 5; e (c) ciclo 6. Os número acima das colunas representam a contribuição da geração em porcentagem do número total de perfilhos. As barras correspondem ao erro padrão da média. 
Apesar de só ter sido detectado efeito de tratamento sobre o número de perfilhos das gerações 2 e 6, a diferença na proporção de cada geração parece estar ligada à menor sobrevivência dos perfilhos nos tratamentos de maior intensidade de pastejo. No tratamento de alta intensidade de pastejo, o número de perfilhos das gerações 1 e 2 não diferiu de zero no ciclo 6 e a partir do ciclo 4, respectivamente (dados não apresentados). Coelho et al. (1999) também observaram maior sobrevivênica de perfilhos remanescentes de capim Tanzânia quando submetido a cortes mais altos. Esses resultados indicam a necessidade de estudos sobre os fatores que interferem na sobrevivênica dos perfilhos.

O peso médio por perfilhos de cada geração aumentou ao longo do período experimental (Tabela 6).

Tabela 6. Efeito do ciclo de pastejo sobre o peso médio dos perfilhos das gerações de capim Tanzânia submetido a três intensidades de pastejo (alta, média e baixa).

\begin{tabular}{ccccc}
\hline Ciclo de pastejo & \multicolumn{4}{c}{ Peso médio por perfilhos (g.perfilho ${ }^{-1}$ ) } \\
\cline { 2 - 5 } & Geração 1 & Geração 2 & Geração 3 & Geração 4 \\
\hline 1 & $0,83^{\mathrm{E}}$ & - & - & - \\
2 & $1,52^{\mathrm{D}}$ & $1,31^{\mathrm{C}}$ & - & - \\
3 & $2,56^{\mathrm{C}}$ & $2,92^{\mathrm{B}}$ & $1,44^{\mathrm{B}}$ & - \\
4 & $4,57^{\mathrm{A}}$ & $5,19^{\mathrm{A}}$ & $3,72^{\mathrm{A}}$ & $2,16^{\mathrm{B}}$ \\
5 & $3,52^{\mathrm{B}}$ & $4,79^{\mathrm{A}}$ & $4,27^{\mathrm{A}}$ & $3,95^{\mathrm{A}}$ \\
\hline
\end{tabular}

Obs: Médias seguidas pela mesma letra na coluna não diferem entre si $(\mathrm{P}>0,15)$.

O aumento do peso médio por perfilho pode estar relacionado, em parte, ao florescimento. Em um experimento com Lollium perenne, Korte et al. (1984) observaram que os perfilhos reprodutivos eram mais pesados que os vegetativos. No presente experimento, os maiores pesos foram observados nos ciclos 4 e 5 , períodos que coincidem com o florescimento.

Para a geração 1 houve efeito de tratamento nos ciclo 1, 3 e 5 (interação entre ciclo de pastejo e tratamento foi significativa) (Tabela 7). Para as demais gerações não houve efeito de tratamento. 
Tabela 7. Efeito da intensidade de pastejo sobre o peso médio por perfilho da geração 1 em cada ciclo de pastejo.

\begin{tabular}{|c|c|c|c|}
\hline \multirow[t]{3}{*}{ Ciclo de pastejo } & \multicolumn{3}{|c|}{ Intensidade de pastejo } \\
\hline & Alta & Média & Baixa \\
\hline & \multicolumn{3}{|c|}{ Peso médio por perfilhos (g.perfilho ${ }^{-1}$ ) } \\
\hline 1 & $0,82^{\mathrm{ab}}$ & $1,00^{\mathrm{a}}$ & $0,66^{\mathrm{b}}$ \\
\hline 2 & $1,24^{\mathrm{a}}$ & $1,73^{\mathrm{a}}$ & $1,60^{\mathrm{a}}$ \\
\hline 3 & $1,75^{\mathrm{b}}$ & $2,49^{\mathrm{ab}}$ & $3,34^{\mathrm{a}}$ \\
\hline 4 & $4,92^{\mathrm{a}}$ & $3,35^{\mathrm{a}}$ & $5,45^{\mathrm{a}}$ \\
\hline 5 & $1,82^{\mathrm{b}}$ & $3,85^{\mathrm{a}}$ & $4,88^{\mathrm{a}}$ \\
\hline
\end{tabular}

Obs: Médias seguidas pela mesma letra na linha não diferem entre si $(\mathrm{P}>0,15)$.

No ciclo 1 , o peso médio por perfilho da geração 1 foi maior no tratamento de média intensidade de pastejo e menor no de alta, enquanto que, nos ciclos 3 e 5 , o peso médio por perfilho aumentou com a redução da intensidade de pastejo.

A redução do peso dos perfilhos da geração 1, entre os ciclos 4 e 5, nas áreas sob pastejo mais intenso, pode ser decorrente da metodologia de amostragem. No ciclo 4 praticamente todos os perfilhos da geração 1 já haviam sido decapitados neste tratamento. Em alguns casos, após a decapitação, os perfilhos rebrotaram a partir de gemas axilares. Esses perfilhos, no momento da coleta, possuíam a marcação correspondente à geração 1 e ainda se encontravam vivos, no entanto, por já terem sido decapitados, eram, em média, mais leves que os demais.

Herling et al. (1998) determinaram que o peso médio dos perfilhos no capim Mombaça

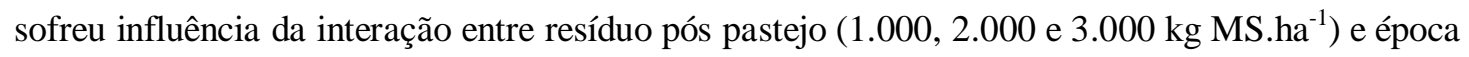
do ano. O mesmo efeito, no entanto, não foi observado por Herling et al. (1999), onde a oferta de forragem $(3,3 ; 4,1$; e 4,9\% do peso vivo) e o período de descanso (28 e 35 dias) não tiveram efeito sobre a densidade populacional de perfilho, o peso médio dos perfilhos e a porcentagem de eliminação de meristema apical do capim Mombaça. A inconsistência do efeito da intensidade de pastejo sobre o peso médio dos perfilhos em $P$. maximum pode ser decorrente de diferenças nos níveis de desfolha adotados, no estádio de desenvolvimento do capim ou na época do ano em que foram desenvolvidos os experimentos. 
Em pastagens de gramíneas temperadas, tem sido observado que existe uma compensação entre peso e número de perfilhos, sendo que a produção se mantêm relativamente estável sob diferentes condições de manejo (Matthew et al., 1995; Grant et al. 1983). No presente experimento, apesar do aumento do peso dos perfilhos ao longo do experimento, o número de perfilhos se manteve relativamente constante entre os ciclos 2 e 6. Herling et al. (1999), comparando o efeito de três ofertas de forragem e dois intervalos entre pastejos no capim Mombaça, observaram correlação positiva entre peso e número de perfilhos. Apesar desses experimentos não terem sido planejados visando ao estudo dos mecanismos de compensação entre peso e número de perfilhos, seus resultados sugerem que existam diferenças fundamentais entre as plantas temperadas e as plantas tropicais cespitosas. Essas diferenças são, provavelmente, decorrentes do alongamento das hastes nas plantas tropicais. No capim Tanzânia, Santos (1997) verificou que o comprimento da pseudo haste variou ao longo do ano de $14,9 \mathrm{~cm}$ em agosto/setembro a 148,6 em abril/maio (florescimento). O alongamento das hastes é acompanhado de mudanças na estrutura da planta e, consequentemente, no coeficiente de extinção (Hay e Walker, 1989). Com isso, pode ocorrer alteração do índice de área foliar teto da cultura, o que determina mudanças no padrão de compensação entre peso e número de perfilhos (Matthew et al., 1995).

A Tabela 8 mostra a contribuição das gerações de perfilhos do capim Tanzânia para a produção de forragem.

Para as gerações 1 e 2 não houve interação entre época do ano e intensidade de pastejo. A maior massa de forragem da geração 1 foi observada no ciclo 1 e a menor no ciclo 5, não havendo diferença entre os demais ciclos, que apresentaram valores intermediários. Já para a geração 2 os maiores valores de massa de forragem foram observados nos ciclos 2 e 4 , sendo que este último não diferiu do ciclo 3. Também para a geração 2 a menor massa de forragem foi observada no ciclo 5. A massa de forragem das duas gerações aumentou com a redução da intensidade de pastejo.

Para as gerações 3 e 4 o efeito de intensidade de pastejo só foi significativo no ciclo 4 (interação entre época do ano e intensidade de pastejo), sendo a massa de forragem mais alta no tratamento de baixa intensidade de pastejo que nos demais. 
Tabela 8. Efeito da intensidade e do ciclo de pastejo sobre a massa de forragem das gerações de perfilhos do capim Tanzânia.

\begin{tabular}{|c|c|c|c|c|}
\hline \multirow[t]{2}{*}{ Ciclo de pastejo } & \multicolumn{3}{|c|}{ Intensidade de pastejo } & \multirow[t]{2}{*}{ Média } \\
\hline & Alta & Média & Baixa & \\
\hline & \multicolumn{4}{|c|}{ Massa de forragem (g MS.m²) - Geração 1} \\
\hline 1 & 544,6 & 737,8 & 433,9 & $572,1^{\mathrm{A}}$ \\
\hline 2 & 243,8 & 347,2 & 276,2 & $289,1^{\mathrm{B}}$ \\
\hline 3 & 116,7 & 244,1 & 289,8 & $216,9^{\mathrm{B}}$ \\
\hline 4 & 85,1 & 201,1 & 465,7 & $250,6^{\mathrm{B}}$ \\
\hline 5 & 30,4 & 136,7 & 203,4 & $123,5^{\mathrm{C}}$ \\
\hline \multirow[t]{2}{*}{ Média } & $204,1^{\mathrm{b}}$ & $333,4^{\mathrm{a}}$ & $333,8^{\mathrm{a}}$ & \\
\hline & \multicolumn{4}{|c|}{ Massa de forragem (g MS.m²) - Geração 2} \\
\hline 2 & 206,8 & 307,0 & 252,9 & $255,6^{\mathrm{A}}$ \\
\hline 3 & 99,3 & 140,9 & 237,8 & $159,3^{\mathrm{B}}$ \\
\hline 4 & 64,4 & 120,5 & 370,7 & $185,2^{\mathrm{AB}}$ \\
\hline 5 & 34,8 & 135,0 & 215,3 & $128,4^{\mathrm{C}}$ \\
\hline \multirow[t]{2}{*}{ Média } & $101,3^{\mathrm{b}}$ & $175,9^{\mathrm{ab}}$ & $269,2^{\mathrm{a}}$ & \\
\hline & \multicolumn{4}{|c|}{ Massa de forragem (g MS.m²) - Geração 3} \\
\hline 3 & $348,3^{\mathrm{a}}$ & $294,0^{\mathrm{a}}$ & $261,7^{\mathrm{a}}$ & 301,3 \\
\hline 4 & $182,7^{\mathrm{b}}$ & $155,3^{\mathrm{b}}$ & $453,0^{\mathrm{a}}$ & 263,7 \\
\hline 5 & $171,8^{\mathrm{a}}$ & $181,9^{\mathrm{a}}$ & $201,7^{\mathrm{a}}$ & 185,2 \\
\hline \multirow[t]{2}{*}{ Média } & 234,3 & 210,4 & 305,5 & \\
\hline & \multicolumn{4}{|c|}{ Massa de forragem (g MS.m²) - Geração 4} \\
\hline 4 & $192,9^{\mathrm{b}}$ & $276,8^{\mathrm{b}}$ & $608,5^{\mathrm{a}}$ & 359,4 \\
\hline 5 & $213,7^{\mathrm{a}}$ & $261,5^{\mathrm{a}}$ & $193,6^{\mathrm{a}}$ & 223,0 \\
\hline \multirow[t]{2}{*}{ Média } & 203,3 & 269,2 & 401,0 & \\
\hline & \multicolumn{4}{|c|}{ Massa de forragem (g MS.m ${ }^{-2}$ ) - Geração 5} \\
\hline 5 & 132,1 & 177,1 & 198,2 & 169,3 \\
\hline
\end{tabular}

Obs: Para cada geração de perfilhos, médias seguidas da mesma letra, maiúscula na coluna e minúscula na linha, não diferem entre si $(\mathrm{P}>0,15)$. 
A maior massa de forragem das gerações de perfilhos no ciclo 4 foi decorrente do aumento do peso médio por perfilho (Tabela 6), visto que o número diminuiu ao longo das avaliações (Tabela 4). Estes resultados mostram que, no ciclo 4, o desenvolvimento do capim Tanzânia sofreu alterações, provavelmente, devido ao início do processo de florescimento.

A Figura 6 mostra a participação relativa de cada geração na massa de forragem total do capim Tanzânia nos ciclos 4 e 5 .

(a)

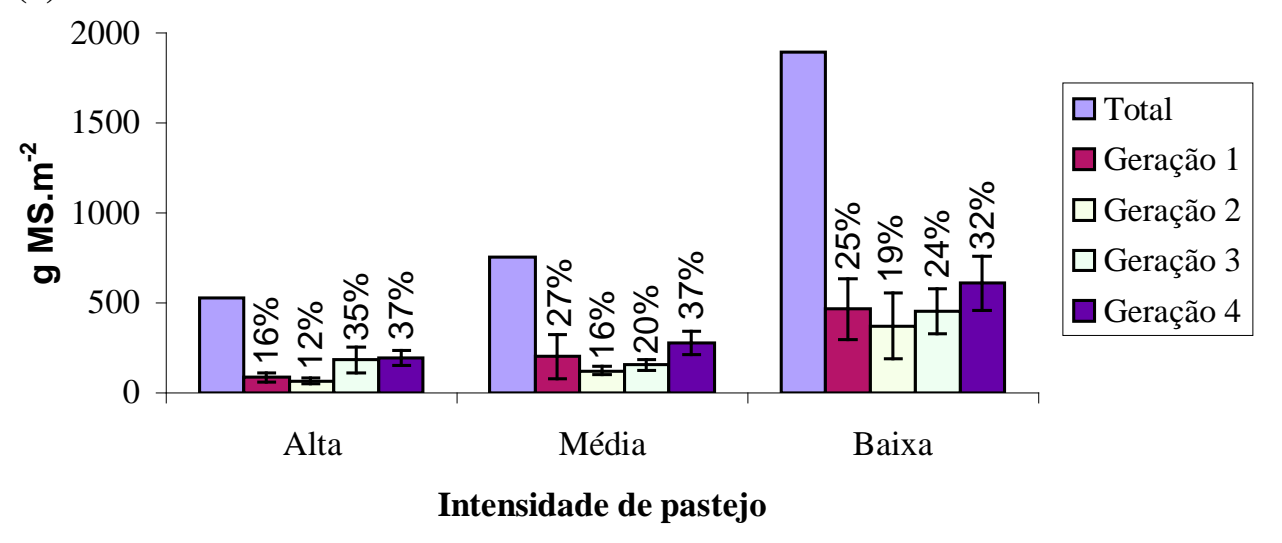

(b)

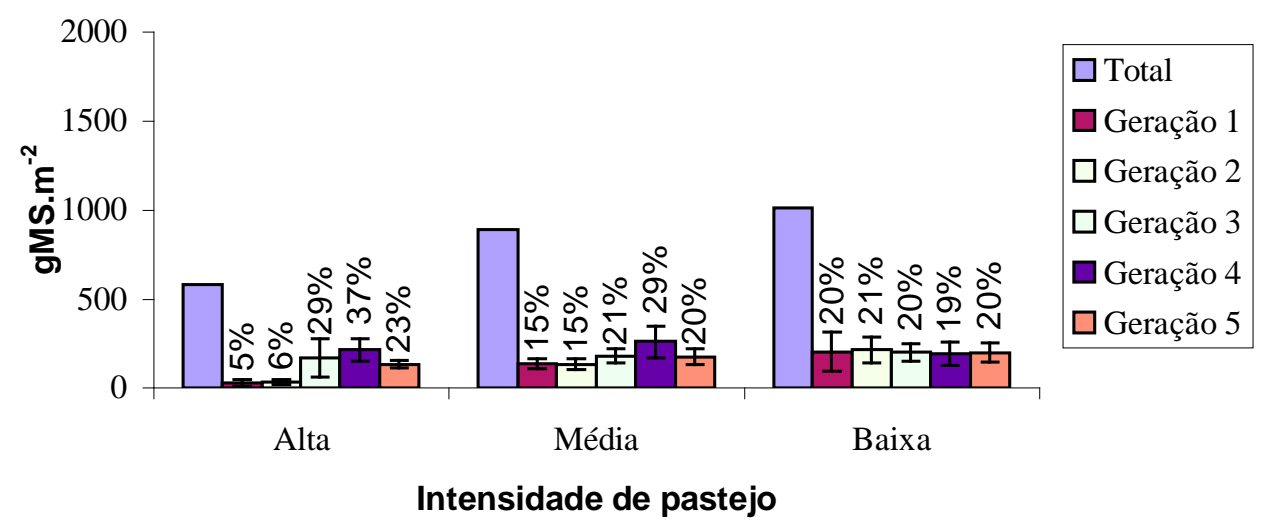

Figura 6 - Efeito da intensidade de pastejo sobre a participação de cada geração na massa de forragem do capim Tanzânia no: (a) ciclo 4; e (b) ciclo 5. Os número acima das colunas representam a contribuição da geração em porcentagem da massa de forragem total. As barras correspondem ao erro padrão da média. 
Santos (1997) sugeriu que, devido à variabilidade na população de perfilhos, o manejo de pastagens de capim Tanzânia fosse programado com base na geração de perfilhos responsável pela maior parte da produção. Os resultados do presente experimento, no entanto, mostram que nenhuma geração de perfilhos se destacou em termos de participação na massa de forragem total, sendo que sua importância relativa dependeu da intensidade de pastejo.

Nas áreas submetidas a alta intensidade de pastejo os perfilhos com mais de 100 dias representaram apenas 16 e $11 \%$ da massa de forragem total nos ciclos 4 e 5 , respectivamente. Nestes mesmos períodos, os perfilhos com mais de 100 dias representaram 25 (ciclo 4) e $41 \%$ (ciclo 5) da massa de forragem total do tratamento de baixa intensidade de pastejo. Korte et al. (1984), trabalhando com azevém, também observaram que os perfilhos novos contribuíam mais para a produção no pastejo mais intenso que no pastejo mais leve.

A porcentagem de folhas na massa de forragem total poder ser vista na Tabela 9. Como a porcentagem de hastes é o complemento da de folhas (100 - \% de folhas), estes dados não serão apresentados.

É importante ressaltar que a avaliação de massa de forragem neste experimento foi um processo pontual, ou seja, não é possível, a partir destes resultados, tirar-se conclusões a respeito da produtividade do capim Tanzânia ao longo das épocas do ano para os tratamentos testados.

Tabela 9. Efeito do ciclo de pastejo sobre porcentagem de folhas das três primeiras gerações de perfilhos do capim Tanzânia submetido a três intensidades de pastejo (alta, média e baixa).

\begin{tabular}{cccc}
\hline Ciclo de pastejo & \multicolumn{3}{c}{ \% de folhas } \\
\cline { 2 - 4 } & Geração 1 & Geração 2 & Geração 3 \\
\hline 1 & $66,9^{\mathrm{A}}$ & - & - \\
2 & $57,2 \mathrm{~B}$ & $58,0^{\mathrm{A}}$ & - \\
3 & $46,6^{\mathrm{C}}$ & $54,0^{\mathrm{B}}$ & $55,3^{\mathrm{A}}$ \\
4 & $37,3^{\mathrm{D}}$ & $36,5^{\mathrm{C}}$ & $45,4^{\mathrm{B}}$ \\
5 & $23,9^{\mathrm{E}}$ & $22,0^{\mathrm{D}}$ & $23,3^{\mathrm{C}}$ \\
\hline
\end{tabular}

Obs: Médias seguidas da mesma letra na coluna não diferem entre si ( $\mathrm{P}>0,15)$. 
Para as gerações 1, 2 e 3 houve efeito apenas do ciclo de pastejo sobre a porcentagem de folhas. A porcentagem de folhas diminui ao longo das avaliações, atingindo valores pouco acima de $20 \%$ no último ciclo.

Para a geração 4 também houve redução da porcentagem de folhas com o avanço dos ciclos, no entanto, neste caso, a interação entre ciclo e intensidade de pastejo foi significativa (Tabela 10). Enquanto no ciclo 4 a porcentagem de folhas diminuiu com a redução da intensidade de pastejo, no ciclo 5 não houve efeito de tratamento sobre esta variável.

Não houve efeito significativo da intensidade de pastejo sobre a porcentagem de folhas da geração 5 .

Tabela 10. Efeito da intensidade e do ciclo de pastejo sobre porcentagem de folhas da quarta geração de perfilhos do capim Tanzânia.

\begin{tabular}{ccccc}
\hline Período do ano & \multicolumn{3}{c}{ Intensidade de pastejo } & Média \\
\cline { 2 - 4 } & Alta & Média & Baixa & \\
\hline & & \multicolumn{2}{c}{$\%$ Folhas } \\
5 & $57,3^{\mathrm{a}}$ & $51,5^{\mathrm{ab}}$ & $43,3^{\mathrm{b}}$ & $50,7^{\mathrm{A}}$ \\
5 & $31,2^{\mathrm{a}}$ & $24,5^{\mathrm{a}}$ & $32,9^{\mathrm{a}}$ & $29,5^{\mathrm{B}}$ \\
\hline
\end{tabular}

Obs: Médias seguidas da mesma letra, maiúscula na coluna e minúscula na linha, não diferem entre si $(\mathrm{P}>0,15)$.

No presente experimento, a porcentagem de folhas foi determinada, principalmente, pelo ciclo de pastejo e pelo estádio de desenvolvimento do capim (só houve efeito de tratamento para a geração 4 no ciclo 4). De modo geral, a porcentagem de folhas foi menor nos ciclos 4 e 5 , que coincidem com o período do florescimento. Santos et al. (1999) obteve resultados semelhantes para o capim Tanzânia, onde a menor porcentagem de folhas observada foi por volta de $25 \%$ no período do florescimento. Em outro experimento desenvolvido por Euclides et al. (1999a), o capim Tanzânia apresentou 22,3\% de folhas no período seco. 
A Figura 7 mostra a proporção de folhas e hastes das gerações do capim Tanzânia submetido a três intensidade de pastejo nos ciclos 4 e 5 .

(a) $100 \%$

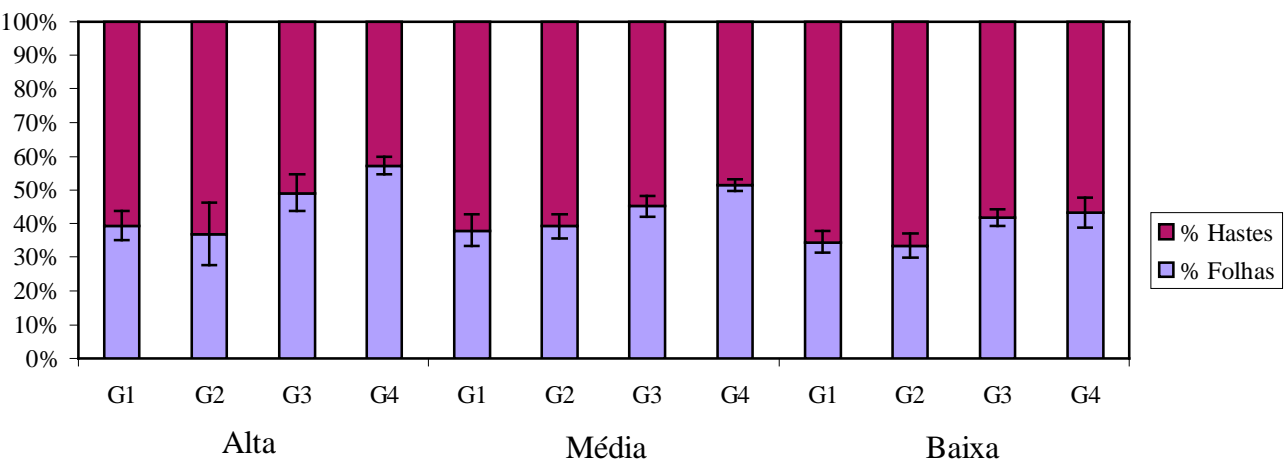

(b)

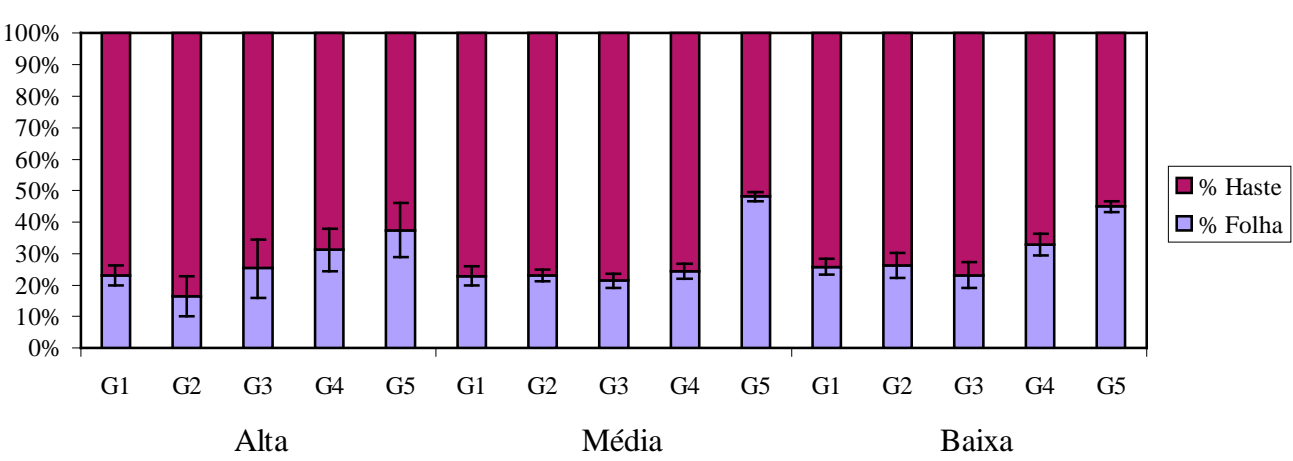

Figura 7 - Efeito da intensidade de pastejo sobre a proporção de folhas e hastes de cada geração do capim Tanzânia no: (a) ciclo 4; e (b) ciclo 5. As barras representam o erro padrão da média.

Estes resultados mostram uma tendência a maior porcentagem de folhas nas duas gerações mais novas. Felippe (1979) determinou que o período juvenil de perfilhos de capim Colonião era correspondente ao aparecimento de cinco a sete folhas. Considerando-se que o capim Tanzânia apresenta um comportamento semelhante, e que sua taxa de aparecimento de folhas seja de 0,1 folhas $\cdot d_{i a}^{-1}$ (Rosseto, 2000), pode-se concluir que o período juvenil seria de 50 a 70 dias. 
No presente experimento, os perfilhos das duas gerações mais novas têm menos de 70 dias. Desta forma, a tendência à maior porcentagem de folhas pode estar ligada ao cumprimento de um período de juvenilidade, durante o qual os perfilhos não estariam susceptíveis à indução floral.

$\mathrm{O}$ incentivo à maior renovação na população de perfilhos, através da manipulação da intensidade e frequiência de pastejo, pode, portanto, ajudar no controle do desenvolvimento das hastes. O sucesso desta estratégia, no entanto, vai depender da capacidade de perfilhamento do capim Tanzânia, o que indica a necessidade de estudos a fim de se determinar os fatores que interferem na taxa de natalidade de perfilhos (ex: fertilidade do solo; dominância apical; viabilidade das gemas; etc).

A Tabela 11 mostra o efeito da intensidade e do ciclo de pastejo sobre a massa de folhas de cada geração de perfilhos do capim Tanzânia.

A massa de folhas das gerações 1, 2, 3 e 4 diminuiu ao longo das avaliações, sendo que para a geração 1 não houve diferença entre os ciclos 3 e 4. Essa redução está ligada ao decréscimo do número de perfilhos das gerações ao longo dos ciclos e ao início do florescimento, uma vez que, após a iniciação floral, o perfilho cessa a produção de folhas.

Houve efeito de intensidade de pastejo sobre a massa de folhas das gerações 1 e 5, sendo esta maior nos tratamentos de média e baixa intensidade de pastejo. Para as gerações 3 e 4 só houve efeito de tratamento no ciclo 4 (interação entre ciclo de pastejo e tratamento foi significativa). Nestes casos, a massa de folhas foi maior para o tratamento de baixa que para os de média e alta intensidade de pastejo. Costa et al. (2000) observaram que a massa de folhas era maior nas áreas submetidas a menor pressão de pastejo.

Euclides et al. (1999b), comparando os capins Colonião, Tobiatã e Tanzânia, concluíram que o consumo de matéria seca era influenciado pela disponibilidade de folhas e pela relação entre material verde e morto. Sollemberger \& Burns (2001), por outro lado, sugerem que o consumo também dependa da facilidade com que as folhas possam ser colhidas separadas das hastes e material morto. Uma maior massa de folhas no tratamento de intensidade de pastejo leve não significa, portanto, que o potencial de consumo dos animais nesta área seja mais elevado, sendo necessário verificar-se a distribuição das folhas no dossel, assim como a facilidade de colheita das mesmas pelos animais. 
Tabela 11. Efeito da intensidade e do ciclo de pastejo sobre a massa de folhas das gerações de perfilhos do capim Tanzânia.

\begin{tabular}{|c|c|c|c|c|}
\hline \multirow[t]{2}{*}{ Ciclo de pastejo } & \multicolumn{3}{|c|}{ Intensidade de pastejo } & \multirow[t]{2}{*}{ Média } \\
\hline & Alta & Média & Baixa & \\
\hline & \multicolumn{4}{|c|}{ Massa de folhas $\left(\mathrm{g} \mathrm{MS} . \mathrm{m}^{-2}\right)$ - Geração 1} \\
\hline 1 & 357,0 & 503,3 & 289,1 & $383,1^{\mathrm{A}}$ \\
\hline 2 & 131,9 & 183,2 & 179,8 & $165,0^{\mathrm{B}}$ \\
\hline 3 & 57,3 & 107,5 & 130,9 & $98,6^{\mathrm{C}}$ \\
\hline 4 & 32,9 & 66,4 & 158,5 & $85,9^{\mathrm{C}}$ \\
\hline 5 & 7,0 & 31,1 & 50,4 & $28,5^{\mathrm{D}}$ \\
\hline \multirow[t]{2}{*}{ Média } & $117,2^{\mathrm{b}}$ & $178,3^{\mathrm{a}}$ & $161,7^{\mathrm{a}}$ & \\
\hline & \multicolumn{4}{|c|}{ Massa de folhas $\left(\mathrm{g}\right.$ MS.m $\left.{ }^{-2}\right)$ - Geração 2} \\
\hline 2 & 116,9 & 174,9 & 145,7 & $145,8^{\mathrm{A}}$ \\
\hline 3 & 54,1 & 74,3 & 115,0 & $81,2^{\mathrm{B}}$ \\
\hline 4 & 13,1 & 49,1 & 110,8 & $57,7^{\mathrm{C}}$ \\
\hline 5 & 6,7 & 29,6 & 54,3 & $30,2^{\mathrm{D}}$ \\
\hline \multirow[t]{2}{*}{ Média } & 47,7 & 82,0 & 106,5 & \\
\hline & \multicolumn{4}{|c|}{ Massa de folhas (g MS.m²) - Geração 3} \\
\hline 3 & $201,4^{\mathrm{a}}$ & $159,6^{\mathrm{a}}$ & $143,3^{\mathrm{a}}$ & $168,1^{\mathrm{A}}$ \\
\hline 4 & $79,4^{\mathrm{b}}$ & $67,8^{\mathrm{b}}$ & $181,7^{\mathrm{a}}$ & $109,6^{\mathrm{B}}$ \\
\hline 5 & $22,5^{\mathrm{a}}$ & $40,3^{\mathrm{a}}$ & $43,3^{\mathrm{a}}$ & $35,3^{\mathrm{C}}$ \\
\hline \multirow[t]{2}{*}{ Média } & 101,1 & 89,2 & 122,8 & \\
\hline & \multicolumn{4}{|c|}{ Massa de folhas $\left(\mathrm{g}\right.$ MS.m $\left.{ }^{-2}\right)$ - Geração 4} \\
\hline 4 & $108,6^{\mathrm{b}}$ & $145,2^{\mathrm{b}}$ & $271,1^{\mathrm{a}}$ & $175,0^{\mathrm{A}}$ \\
\hline 5 & $56,7^{\mathrm{a}}$ & $58,7^{\mathrm{a}}$ & $63,5^{\mathrm{a}}$ & $59,6^{\mathrm{B}}$ \\
\hline \multirow[t]{2}{*}{ Média } & 82,6 & 101,9 & 167,3 & \\
\hline & \multicolumn{4}{|c|}{ Massa de folhas (g MS.m²) - Geração 5} \\
\hline 5 & $46,3^{\mathrm{b}}$ & $84,2^{\mathrm{a}}$ & $86,7^{\mathrm{a}}$ & 72,4 \\
\hline
\end{tabular}

Obs: Para cada geração de perfilhos, médias seguidas da mesma letra, maiúscula na coluna e minúscula na linha, não diferem entre si $(\mathrm{P}>0,15)$. 
Na Tabela 12 pode-se observar o efeito da intensidade e do ciclo de pastejo sobre a massa de hastes do capim Tanzânia.

A massa de hastes da geração 1 foi maior no primeiro e quarto ciclos, não havendo diferença entre este último e os ciclos 2 e 3 . O ciclo 5 também não diferiu estatisticamente dos ciclos 2 e 3. Também houve efeito de tratamento sobre a massa de hastes da geração 1, sendo que esta aumentou com a redução da intensidade de pastejo.

Para as gerações 2, 3 e 4 houve interação entre intensidade e ciclo de pastejo. Não foi detectado efeito de tratamento sobre a massa de hastes da geração 2 no ciclo 2, porém, nos ciclos 3 e 4, a massa de hastes foi maior no tratamento de baixa intensidade de pastejo e, no ciclo 5, nos tratamentos de média e baixa intensidade.

Para as gerações 3 e 4 só houve efeito de tratamento no ciclo 4, quando a massa de hastes foi maior para o tratamento de baixa intensidade de pastejo.

A maior massa de hastes nas áreas submetidas a pastejos mais leves confirma que apenas a massa de folhas não é um bom indicativo do potencial de consumo dos animais, e que são necessários estudos onde seja investigado o efeito da arquitetura das plantas e da distribuição das folhas no dossel sobre a facilidade de colheita de forragem pelos animais.

O aumento da massa de hastes a partir do ciclo 4 é decorrente do início do florescimento. Neste experimento, as primeiras inflorescências foram observadas durante este ciclo.

Os resultados apresentados nas Tabelas 6, 7, 8, 11 e 12 mostram que as alterações na estrutura do pasto devidas ao florescimento se tornam evidentes a partir do ciclo 4, ou seja, qualquer medida no sentido de controlar o desenvolvimento das hastes no capim Tanzânia deve ser tomada antes deste período (fevereiro). 
Tabela 12. Efeito da intensidade e do ciclo de pastejo e sobre a massa de hastes das gerações de perfilhos do capim Tanzânia.

\begin{tabular}{|c|c|c|c|c|}
\hline \multirow[t]{2}{*}{ Ciclo de pastejo } & \multicolumn{3}{|c|}{ Intensidade de pastejo } & \multirow[t]{2}{*}{ Média } \\
\hline & Alta & Média & Baixa & \\
\hline & \multicolumn{4}{|c|}{ Massa de hastes $\left(\mathrm{g} \mathrm{MS} . \mathrm{m}^{-2}\right)$ - Geração 1} \\
\hline 1 & 187,6 & 234,6 & 144,8 & $189,0^{\mathrm{A}}$ \\
\hline 2 & 111,9 & 164,0 & 96,5 & $124,1^{\mathrm{BC}}$ \\
\hline 3 & 59,5 & 136,6 & 158,9 & $118,3^{\mathrm{BC}}$ \\
\hline 4 & 52,2 & 131,6 & 307,2 & $163,7^{\mathrm{AB}}$ \\
\hline 5 & 23,3 & 105,6 & 153,0 & $94,0^{\mathrm{C}}$ \\
\hline \multirow[t]{2}{*}{ Média } & $86,9^{\mathrm{b}}$ & $154,5^{\mathrm{ab}}$ & $172,1^{\mathrm{a}}$ & \\
\hline & \multicolumn{4}{|c|}{ Massa de hastes $\left(\mathrm{g}\right.$ MS.m $\left.{ }^{-2}\right)$ - Geração 2} \\
\hline 2 & $89,9^{\mathrm{a}}$ & $132,1^{\mathrm{a}}$ & $107,1^{\mathrm{a}}$ & 109,7 \\
\hline 3 & $45,1^{\mathrm{b}}$ & $66,5^{\mathrm{b}}$ & $122,8^{\mathrm{a}}$ & 78,1 \\
\hline 4 & $19,9^{\mathrm{b}}$ & $71,4^{\mathrm{b}}$ & $259,9^{\mathrm{a}}$ & 117,1 \\
\hline 5 & $25,6^{\mathrm{b}}$ & $105,4^{\mathrm{a}}$ & $161,0^{\mathrm{a}}$ & 97,3 \\
\hline \multirow[t]{2}{*}{ Média } & 45,1 & 93,9 & 162,7 & \\
\hline & \multicolumn{4}{|c|}{ Massa de hastes $\left(\mathrm{g}\right.$ MS.m² ${ }^{-2}$ - Geração 3} \\
\hline 3 & $146,8^{\mathrm{a}}$ & $134,4^{\mathrm{a}}$ & $118,4^{\mathrm{a}}$ & 133,2 \\
\hline 4 & $103,3^{\mathrm{b}}$ & $87,5^{\mathrm{b}}$ & $271,3^{\mathrm{a}}$ & 154,0 \\
\hline 5 & $149,4^{\mathrm{a}}$ & $141,6^{\mathrm{a}}$ & $158,4^{\mathrm{a}}$ & 149,8 \\
\hline \multirow[t]{2}{*}{ Média } & 133,2 & 121,2 & 182,7 & \\
\hline & \multicolumn{4}{|c|}{ Massa de hastes $\left(\mathrm{g} \mathrm{MS} . \mathrm{m}^{-2}\right)$ - Geração 4} \\
\hline 4 & $84,4^{\mathrm{b}}$ & $131,7^{\mathrm{b}}$ & $337,3^{\mathrm{a}}$ & 184,5 \\
\hline 5 & $157,0^{\mathrm{a}}$ & $202,9^{\mathrm{a}}$ & $130,2^{\mathrm{a}}$ & 163,4 \\
\hline \multirow[t]{2}{*}{ Média } & 120,7 & 167,3 & 233,8 & \\
\hline & \multicolumn{4}{|c|}{ Massa de hastes (g MS.m-2) - Geração 5} \\
\hline 5 & 85,7 & 92,9 & 111,5 & 96,7 \\
\hline
\end{tabular}

Obs: Para cada geração de perfilhos, médias seguidas da mesma letra, maiúscula na coluna e minúscula na linha, não diferem entre si $(\mathrm{P}>0,15)$. 
As figuras 8 e 9 mostram a proporção de cada geração de massa seca total de folhas e hastes do capim Tanzânia submetido a três intensidades de pastejo nos ciclos 4 e 5 .

(a)

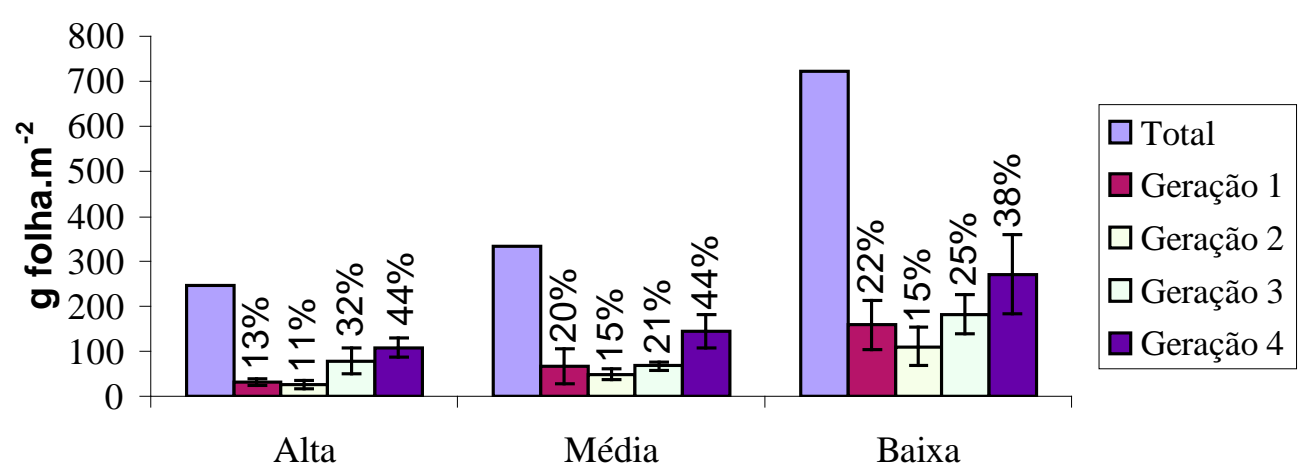

Intensidade de pastejo

(b)

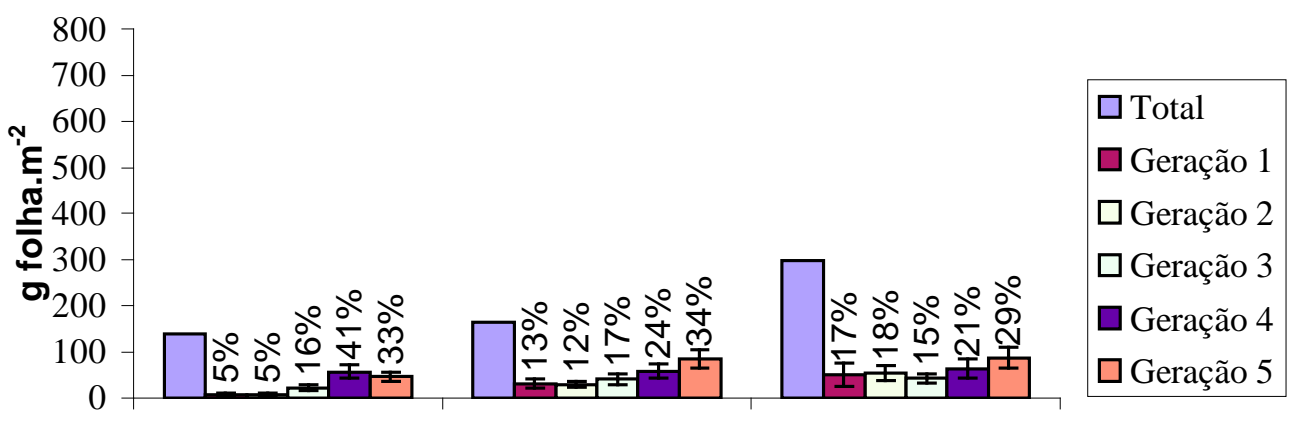

Alta

Média

Baixa

Intensidade de pastejo

Figura 8 - Efeito da intensidade de pastejo sobre a participação de cada geração na massa de folhas do capim Tanzânia no: (a) ciclo 4; e (b) ciclo 5. Os número acima das colunas representam a contribuição da geração em porcentagem da massa de folhas total. As barras correspondem ao erro padrão da média. 
(a)

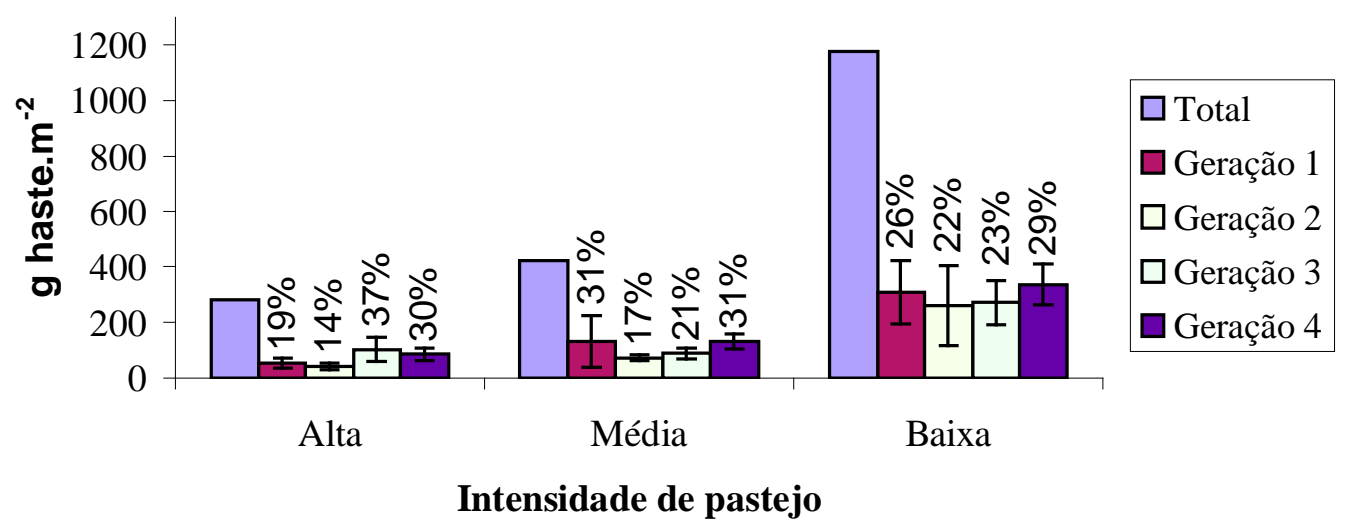

(b)

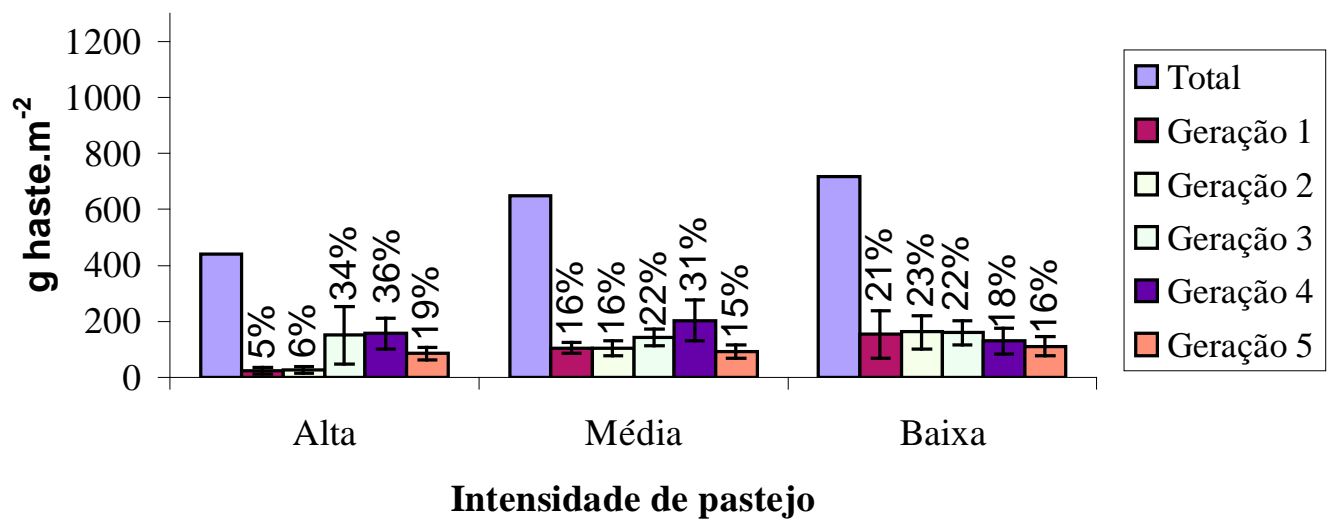

Figura 9 - Efeito da intensidade de pastejo sobre a participação de cada geração na massa de hastes do capim Tanzânia no: (a) ciclo 4; e (b) ciclo 5. Os número acima das colunas representam a contribuição da geração em porcentagem da massa de hastes total. As barras correspondem ao erro padrão da média.

A participação das gerações na massa de hastes e folhas segue, em linhas gerais, o mesmo padrão observado para massa de forragem. Nenhuma geração de perfilhos se destaca em termos de contribuição para a produção de hastes e folhas, sendo que, nas áreas submetidas a pastejo mais intenso, a participação das gerações mais velhas na produção de hastes e folhas é menor que 
nas áreas sob pastejo mais leve. Esta tendência é mais clara no ciclo 5, quando as gerações com mais de 100 dias representavam $11 \%$ e $10 \%$ da massa de hastes e folhas, respectivamente, no tratamento de alta intensidade de pastejo. No tratamento de baixa intensidade, por sua vez, as gerações com mais de 100 dias eram responsáveis por 44 e 35\% da produção de hastes e folhas, respectivamente.

Os resultados do presente experimento indicam que, no capim Tanzânia, o controle do desenvolvimento das hastes, através de um único corte estratégico que eliminasse determinado grupo de perfilhos não é viável, pois não foi possível identificar uma geração de perfilhos particularmente responsável pelo aumento da participação das hastes na produção.

Diversos trabalhos mostram que a qualidade da forragem decresce com a idade. A participação das gerações de perfilhos com mais de 100 dias na produção total de forragem aumenta com a redução da intensidade de pastejo. Além disso, Andrade (1987) determinou, para três cultivares de Panicum maximum, que a qualidade das hastes diminuía mais rapidamente que a das folhas com o avanço da idade. A alta proporção de hastes proveniente das gerações mais velhas no tratamento de baixa intensidade de pastejo deve, portanto, ter efeito prejudicial sobre o valor alimentar da forragem.

As Tabelas 13, 14 e 15 mostram a digestibilidade "in vitro" da matéria orgânica de amostras das gerações de perfilhos do capim Tanzânia. Foram analisadas amostras apenas do ciclo 2 em diante.

Tabela 13. Efeito do ciclo de pastejo sobre a digestibilidade "in vitro" da matéria orgânica das gerações de perfilhos do capim Tanzânia.

\begin{tabular}{cccc}
\hline Ciclo de pastejo & \multicolumn{3}{c}{ Digestibilidade (\%) } \\
\cline { 2 - 4 } & Geração 1 & Geração 3 & Geração 4 \\
\hline 2 & $58,4^{\mathrm{A}}$ & & \\
3 & $54,2^{\mathrm{B}}$ & $59,1^{\mathrm{A}}$ & \\
4 & $52,5^{\mathrm{B}}$ & $60,5^{\mathrm{A}}$ & $61,1^{\mathrm{A}}$ \\
5 & $44,8^{\mathrm{C}}$ & $49,1^{\mathrm{B}}$ & $48,3^{\mathrm{B}}$ \\
\hline
\end{tabular}

Obs: Médias seguidas da mesma letra na coluna não diferem entre si $(\mathrm{P}>0,15)$. 
Tabela 14. Efeito da intensidade de pastejo sobre a digestibilidade "in vitro" da matéria orgânica das gerações de perfilhos do capim Tanzânia.

\begin{tabular}{cccc}
\hline Geração & \multicolumn{3}{c}{ Intensidade de pastejo } \\
\cline { 2 - 4 } & Alta & Média & Baixa \\
\hline & & Digestibilidade (\%) \\
3 & $56,6^{\mathrm{a}}$ & $52,0^{\mathrm{ab}}$ & $48,8^{\mathrm{b}}$ \\
4 & $58,4^{\mathrm{a}}$ & $52,3^{\mathrm{b}}$ & $55,0^{\mathrm{b}}$ \\
4 & $57,2^{\mathrm{a}}$ & $55,6^{\mathrm{a}}$ & $51,4^{\mathrm{b}}$ \\
\hline
\end{tabular}

Obs: Médias seguidas da mesma letra na linha não diferem entre si $(\mathrm{P}>0,15)$.

Para as gerações 1, 3 e 4 houve efeito de ciclo e intensidade de pastejo sobre a digestibilidade, sendo que esta diminuiu ao longo das avaliações (Tabelas 13 e 14). Para as gerações 1 e 3, a digestibilidade foi maior no tratamento de alta intensidade de pastejo, não havendo diferença entre os demais. Já para a geração 4, a digestibilidade foi menor para as áreas submetidas ao pastejo mais leve, não havendo diferença entre os tratamentos de média e alta intensidade de pastejo.

Tabela 15. Efeito da intensidade e do ciclo de pastejo sobre a digestibilidade "in vitro" da matéria orgânica da segunda geração de perfilhos do capim Tanzânia.

\begin{tabular}{ccccc}
\hline Ciclo de pastejo & \multicolumn{3}{c}{ Intensidade de pastejo } & Média \\
\cline { 2 - 3 } & Alta & Média & Baixa \\
\hline & & Digestibilidade (\%) - Geração 2 & \\
3 & $56,1^{\mathrm{a}}$ & $62,4^{\mathrm{a}}$ & $58,6^{\mathrm{a}}$ & $59,0^{\mathrm{A}}$ \\
4 & $54,1^{\mathrm{a}}$ & $52,5^{\mathrm{a}}$ & $57,5^{\mathrm{a}}$ & $54,7^{\mathrm{B}}$ \\
5 & $62,8^{\mathrm{a}}$ & $50,6^{\mathrm{c}}$ & $56,4^{\mathrm{b}}$ & $56,6^{\mathrm{AB}}$ \\
\hline
\end{tabular}

Obs: Médias seguidas da mesma letra, minúscula na linha e maiúscula na coluna, não diferem entre si $(\mathrm{P}>0,15)$. 
Os efeitos de ciclo e da interação entre ciclo e intensidade de pastejo foram significativos para a digestibilidade da geração 2 (Tabela 15). Neste caso, a digestibilidade também decresceu ao longo das avaliações, porém o efeito de tratamento só foi significativo nos ciclos 4 e 5 . Em ambos os ciclos, a digestibilidade foi maior para o tratamento de alta intensidade de pastejo, sendo que no ciclo 4 a menor digestibilidade foi para o tratamento de média intensidade, enquanto que no ciclo 5 foi para o de baixa intensidade de pastejo.

Para a geração 5 não houve efeito de ciclo e nem de intensidade de pastejo.

Os resultados acima mostram que, de modo geral, a digestibilidade dos perfilhos foi melhor nas áreas submetidas a alta intensidade de pastejo, o que, em parte, pode ser atribuído à menor massa de hastes destes perfilhos. Por outro lado, Wilson \& Wong (1982) observaram que, em $P$. maximum cv. green panic, o sombreamento determinava redução da digestibilidade, associada ao menor teor de carboidratos solúveis, à maior lignificação, e à uma possível redução da digestibilidade da parede celular. A maior massa de forragem observada no tratamento de baixa intensidade de pastejo sugere que a competição por luz durante a fase inicial de desenvovimento dos perfilhos seja maior neste tratamento. Desta forma, a menor digestibilidade dos perfilhos provenientes de áreas sob pastejo mais leniente pode também ter sido decorrente do ambiente luminoso em que estes se desenvolveram.

A acentuada redução na digestibilidade das gerações ao longo dos ciclos de pastejo (diminuição de 3 a 6 pontos percentuais de digestibilidade por ciclo), aliada à melhor digestibilidade dos perfilhos provenientes de áreas sob pastejo pesado, indicam que a busca de uma maior renovação na população de perfilhos a partir de fevereiro é a alternativa mais viável para se evitar os efeitos negativos do florescimento sobre a produção animal em pastagens de capim Tanzânia.

O planejamento do manejo a fim de se atingir este objetivo deve, no entanto, ser feito com cautela. O aumento da intensidade de pastejo pode ser uma alternativa, porém o seu sucesso vai depender do sistema de produção em questão. Rego et al. (2001) observaram que os estratos superiores do capim Tanzânia apresentavam melhor valor nutritivo que os inferiores. Com o aumento da intensidade de pastejo, portanto, os animais serão forçados a pastejar estratos de qualidade inferior. Desta forma, o aumento da intensidade de pastejo só deve ser adotada caso haja uma categoria animal de menor exigência que possa ser utilizada. 
Outra alternativa seria a alteração da frequiência de pastejo. Felippe (1979) determinou que, no capim Colonião, mesmo os perfilhos que haviam encerrado o período juvenil precisavam produzir um mínimo de quatro folhas antes que ocorresse a iniciação floral. Caso este mesmo mecanismo seja observado no capim Tanzânia, o intervalo entre pastejos a partir de fevereiro/março poderia ser determinado com base na taxa de aparecimento de folhas.

O correto estabelecimento da melhor combinação entre freqüência e intensidade de pastejo depende, no entanto, de novos estudos que determinem as conseqüências destas medidas sobre o pasto. Tallowin et al. (1989) observaram que, mudanças na pressão de pastejo durante o período de florescimento, em áreas de azevém sob pastejo continuo, determinaram alterações na estrutura do pasto que interferiram no desenvolvimento reprodutivo das plantas no ano seguinte.

A adoção de qualquer dessas práticas nas fazendas não é simples, principalmente naquelas formadas exclusivamente por cultivares Panicum maximum. Para elevar a intensidade de pastejo a partir de fevereiro, por exemplo, é necessário aumentar a taxa de lotação do pasto neste período. Em fazendas onde há áreas formadas por espécies com hábitos de florescimento diferentes, pode-se tentar aumentar a taxa de lotação transferindo-se animais de uma área para outra durante a fase do florescimento. Já em fazendas onde todos os pastos são de capim Tanzânia (ou de espécies de mesmo hábito de florescimento), seria necessária a introdução de animais no sistema por um curto espaço de tempo, o que, geralmente, é inviável. Por outro lado, devido à estacionalidade de produção, a maior parte das propriedades no Brasil trabalha, em maior ou menor grau, com o diferimento de pastagens. As alternativas de manejo propostas neste trabalho reduziriam o estoque de forragem disponível para o período das secas, o que nem sempre é interessante. Assim sendo, a adequação destas estratégias de manejo aos sistemas de produção adotados nas propriedades comerciais representa um desafio aos pesquisadores, aos técnicos e aos produtores.

\subsection{Experimento 2}

A massa seca da planta inteira aumentou ao longo das coletas tanto para o tratamento $+\mathrm{N}$ quanto para o tratamento Zero $\mathrm{N}(\mathrm{P}<0,001)$, sendo que o aumento foi maior para as plantas que continuaram recebendo nitrogênio $(\mathrm{P}<0,01)$ (Figura 10). Walker et al. (2001), em um experimento 
com alface (Lactuca sativa L.), observaram que as plantas não foram capazes de mobilizar suas reservas em velocidade suficiente para evitar a redução do crescimento, quando o fornecimento externo de $\mathrm{N}$ foi suprimido.

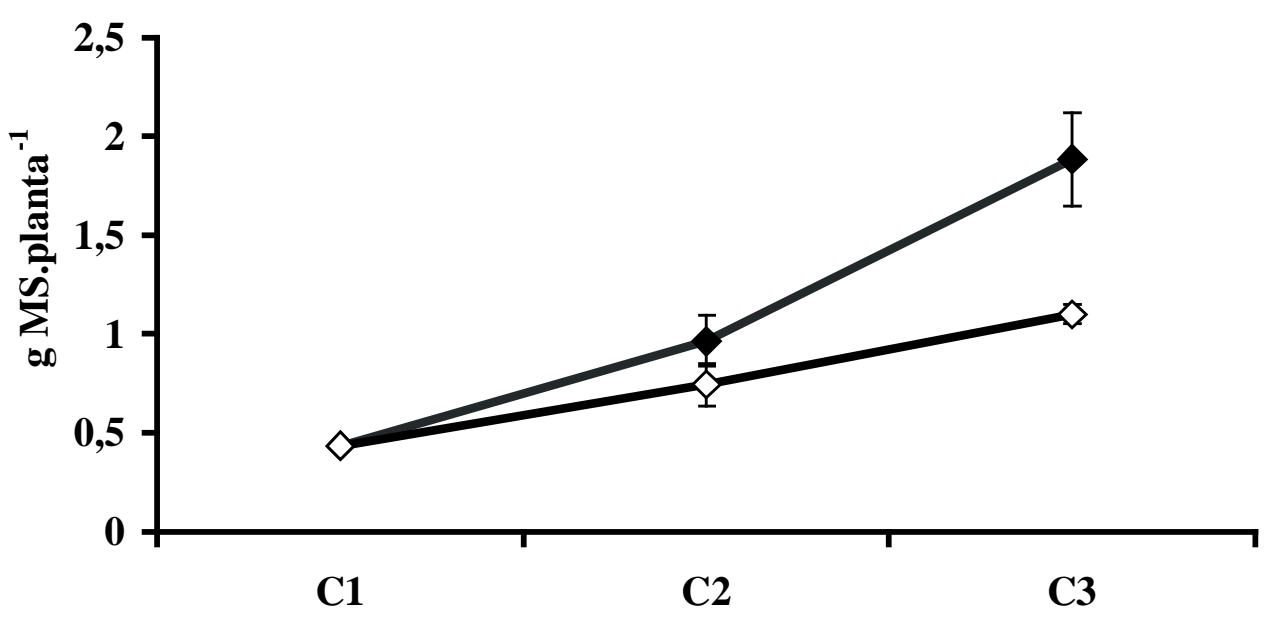

Coleta

Figura 10 - Massa seca total do capim Tanzânia (g.planta ${ }^{-1}$ ). Os símbolos fechados correspondem ao tratamento $+\mathrm{N}$ e os abertos ao zero $\mathrm{N}$. As barras, quando maiores que os símbolos, representam o erro padrão da média.

A massa dos perfilhos laterais, hastes e folhas em expansão foi maior nos tratamentos + N. Por outro lado, não houve efeito de nitrogênio sobre a massa de raízes (Tabela 16). A maior massa das plantas recebendo nitrogênio foi, portanto, decorrente do maior crescimento da parte aérea. 
Tabela 16. Massa seca (g.planta ${ }^{-1}$ ) das partes da planta de capim Tanzânia recebendo ou não nitrogênio.

\begin{tabular}{|c|c|c|c|c|c|c|c|c|c|}
\hline \multirow[t]{3}{*}{ Parte da planta } & \multirow[t]{2}{*}{$1^{\underline{a}}$ coleta } & \multicolumn{2}{|c|}{$2^{\mathrm{a}}$ coleta } & \multicolumn{2}{|c|}{$3^{\mathrm{a}}$ coleta } & \multicolumn{4}{|c|}{ Contrastes $^{1}$} \\
\hline & & $+\mathrm{N}$ & Zero $\mathrm{N}$ & $+\mathrm{N}$ & Zero $\mathrm{N}$ & $1^{\frac{a}{a}} \times 2^{\underline{a}}$ e $3^{\frac{a}{a}}$ & $2^{\mathrm{a}} \times 3^{\mathrm{a}}$ coleta & $+\mathrm{N} x$ Zero & $\mathrm{N} \times$ coleta \\
\hline & \multicolumn{5}{|c|}{ Massa seca (g.planta $\left.{ }^{-1}\right)$} & coletas & & $\mathrm{N}$ & \\
\hline Perf. Lateral & 0,0131 & 0,1288 & 0,0363 & 0,3996 & 0,1042 & $* * *$ & $* * *$ & $* * *$ & NS \\
\hline Raiz & 0,1680 & 0,4146 & 0,3873 & 0,6862 & 0,4459 & $* * *$ & $*$ & NS & NS \\
\hline Haste & 0,0125 & 0,0220 & 0,0156 & 0,0501 & 0,0283 & $* * *$ & $* * *$ & $* * *$ & NS \\
\hline Folhas 1 a 3 & 0,0084 & 0,0082 & 0,0066 & 0,0072 & 0,0066 & NS & NS & NS & NS \\
\hline Folha 4 & 0,0151 & 0,0136 & 0,0110 & 0,0166 & 0,0141 & NS & NS & NS & NS \\
\hline Folha 5 & 0,0266 & 0,0290 & 0,0232 & 0,0327 & 0,0321 & NS & NS & NS & NS \\
\hline Folha 6 & 0,0519 & 0,0539 & 0,0459 & 0,0640 & 0,0644 & NS & $* *$ & NS & NS \\
\hline Folha 7 & 0,0800 & 0,0870 & 0,0769 & 0,1008 & 0,1019 & NS & $* *$ & NS & NS \\
\hline Folha 8 & 0,0540 & 0,1114 & 0,0901 & 0,1427 & 0,1448 & $* * *$ & $* * *$ & NS & NS \\
\hline Folhas 9 to 13 & 0,0053 & 0,0966 & 0,0508 & 0,3820 & 0,1578 & $* * *$ & $* * *$ & $* * *$ & NS \\
\hline
\end{tabular}

${ }^{1} \mathrm{NS}=\mathrm{P}>0,05 ; * \mathrm{P}<0,05 ; * * \mathrm{P}<0,01 ; * * * \mathrm{P}<0,001$ 
A redução da massa de parte aérea sem a concomitante redução da massa de sistema radicular indica que houve uma alteração na partição de carboidratos entre raiz e parte aérea, devido à deficiência de nitrogênio. Em média, no tratamento $+\mathrm{N}$ o sistema radicular representou $40 \%$ da massa das plantas, enquanto que no tratamento zero $\mathrm{N}$ ele representou $47 \%$. Essa alteração da partição de carboidratos em favor do sistema radicular devido à deficiência de nitrogênio têm sido relatada para diversas espécies (Ericson, 1995; Marschner et al., 1996; Erley, 2000). Lemaire \& Millard (1999), no entanto, lembram que a relação raiz : parte aérea deve ser analisada com cuidado, pois não traz informações sobre o nível de atividade dos tecidos.

Para o capim Tanzânia recebendo nitrogênio, o aumento da massa seca ocorreu de forma concomitante ao aumento no conteúdo de $\mathrm{N}$ total das plantas $(\mathrm{P}<0,001)$ (Figuras 10 e 11). Já para as plantas recebendo o tratamento Zero $\mathrm{N}$, houve aumento na massa seca mesmo sem haver alteração no conteúdo de $\mathrm{N}$ total ao longo do período experimental (Figuras 10 e 11). A resposta de uma planta à deficiência de nitrogênio é resultante do balanço entre o aumento da área foliar e a redução da concentração de N. Lemaire \& Millard (1999) sugerem que o ponto de equilíbrio deste balanço depende do grupo funcional da planta $\left(\mathrm{C}_{3} \times \mathrm{C}_{4}\right)$, pois a concentração foliar de nitrogênio ótima para a fotossíntese varia.

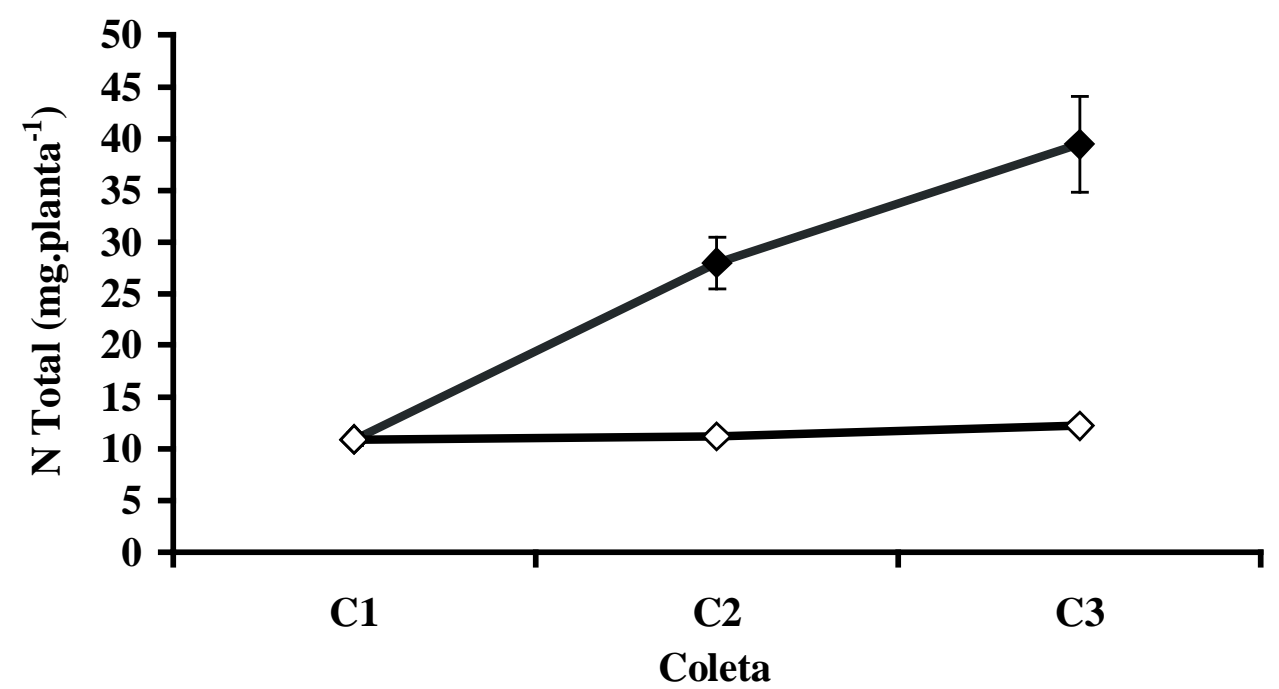

Figura 11 - Conteúdo de N total do capim Tanzânia (mg.planta-1). Os símbolos fechados correspondem ao tratamento $+\mathrm{N}$ e os abertos ao zero $\mathrm{N}$. As barras, quando maiores que os símbolos, representam o erro padrão da média. 
Apenas os tratamentos que receberam ${ }^{15} \mathrm{~N}$ foram considerados na análise estatística do conteúdo de nitrogênio marcado (nos outros tratamentos o conteúdo de $\mathrm{N}$ marcado foi zero). No tratamento $+\mathrm{N}$, o conteúdo de nitrogênio marcado aumentou ao longo das coletas $(\mathrm{P}<0,05)$ (Figura 12).

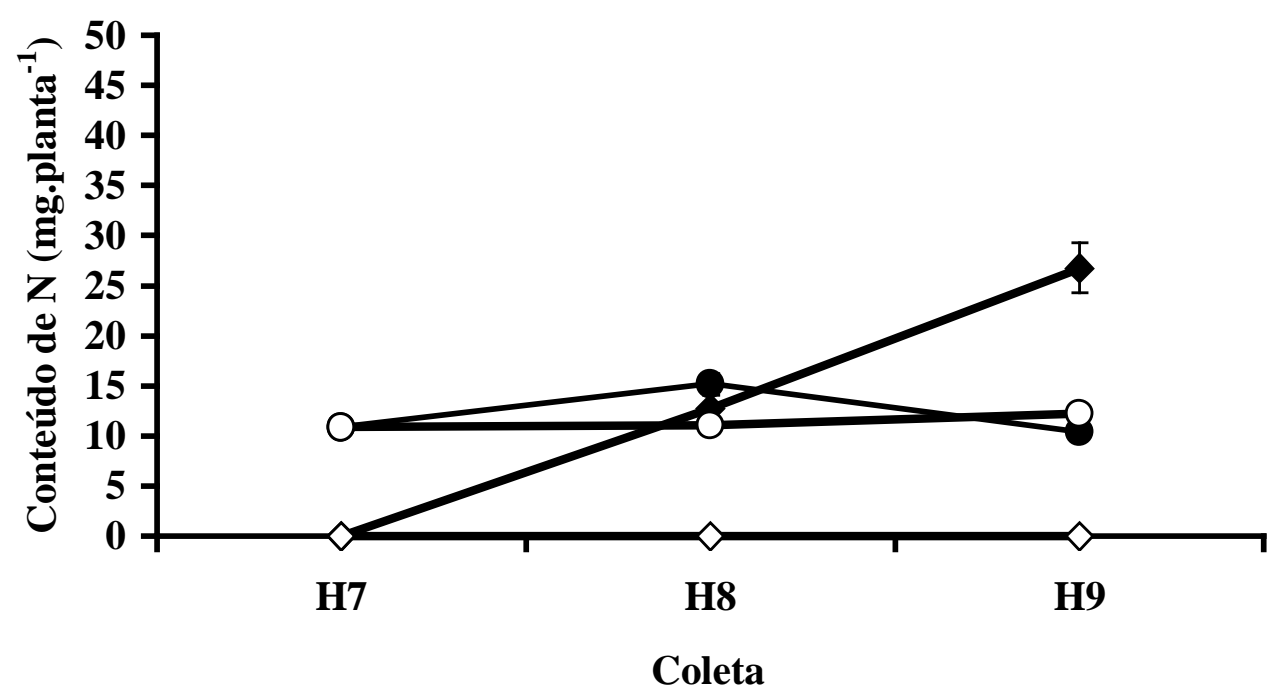

Figura 12 - Conteúdo de nitrogênio marcado $(\bullet$ tratamento $+\mathrm{N}$; $\diamond$ tratamento zero $\mathrm{N}$ ) e não marcado $(\bullet$ tratamento $+\mathrm{N}$; o tratamento zero $\mathrm{N}$ ) de plantas de capim Tanzânia, expresso em mg.planta-1. As barras, quando maiores que os símbolos, representam o erro padrão da média.

O conteúdo de $\mathrm{N}$ não marcado se manteve inalterado ao longo das coletas para as plantas recebendo o tratamento Zero N (P>0,05) (Figura 12). O nitrogênio não marcado nestas plantas pode, então, ser considerado como um sistema fechado sem nenhuma perda significativa de $\mathrm{N}$ (ex: através de renovação do sistema radicular ou exudação) ao longo do experimento. 
Para as plantas recebendo nitrogênio, no entanto, o conteúdo de nitrogênio não marcado foi maior na segunda coleta $(\mathrm{P}<0,01)$ (Figura 12). Como não houve diferença no conteúdo de $\mathrm{N}$ não marcado entre a primeira e a terceira coleta $(\mathrm{P}>0,05)$, considerou-se que o aumento de $\mathrm{N}$ não marcado na segunda coleta não representava uma mudança sistemática ao longo das coletas e que os dados poderiam, portanto, ser "corrigidos".

Duas metodologias foram adotadas para "corrigir" os dados de conteúdo de nitrogênio não marcado na segunda coleta. Na primeira, considerou-se que não houve absorção de nitrogênio não marcado entre a primeira e a segunda coleta. Desta forma, o conteúdo de nitrogênio não marcado de todas as partes da plantas foi recalculado utilizando-se o índice: conteúdo médio de $\mathrm{N}$ não marcado da planta toda na primeira coleta/conteúdo médio de $\mathrm{N}$ não marcado da planta toda na segunda coleta. No segundo caso, considerou-se que, por algum motivo, houve absorção de nitrogênio não marcado entre a primeira e a segunda coleta. Assim sendo, o aumento médio no nitrogênio não marcado entre as duas primeiras coletas foi considerado como absorção radicular e adicionado ao $\mathrm{N}$ marcado, assumindo-se que a sua distribuição entre as partes da planta seguiu o mesmo padrão que a partição do nitrogênio marcado ao logo das coletas. Como a interpretação dos resultados não foi alterada pelo método de correção adotado, apenas os dados da segunda metodologia serão apresentados.

A Figura 13 mostra a variação no conteúdo de nitrogênio total ocorrida em cada parte da planta entre as diversas coletas. Para as plantas recebendo nitrogênio, estas mudanças representam a variação total, decorrente da partição do nitrogênio absorvido e da remobilização de nitrogênio endógeno (Figuras 13a e 13b). Para o tratamento Zero N, esta variação representa a remobilização de nitrogênio (Figuras 13c e 13d).

A redistribuição do nitrogênio não marcado e a partição do nitrogênio marcado para o tratamento $+\mathrm{N}$ podem ser vistas nas Figura 14 e 15 . 
(a)

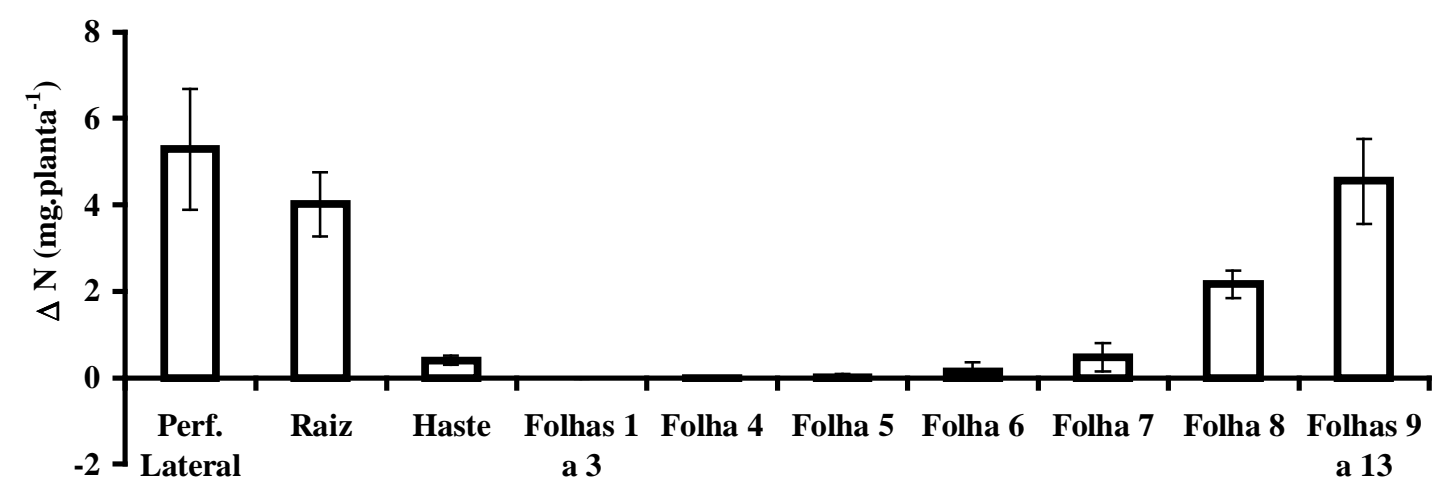

(b)

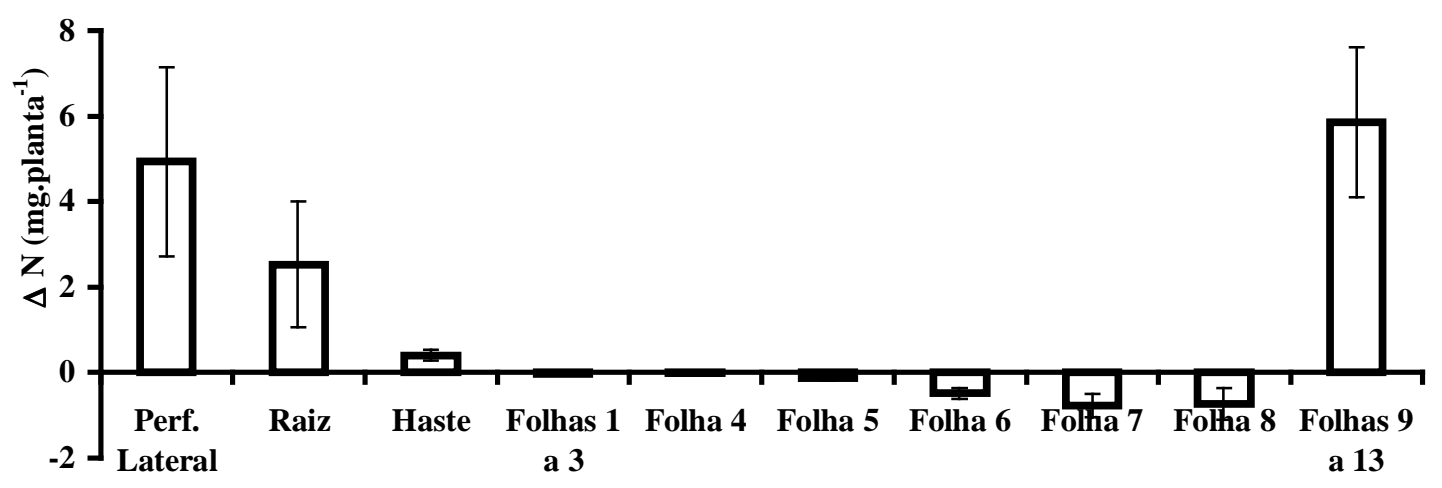

Figura 13 - Variação no conteúdo de N total de partes da planta de capim Tanzânia: (a) diferença entre a primeira e a segunda coleta do tratamento $+\mathrm{N}$; (b) diferença entre a segunda e a terceira coleta do tratamento $+\mathrm{N}$; (c) diferença entre a primeira e a segunda coleta do tratamento zero N; (d) diferença entre a segunda e a terceira coleta do tratamento zero N. As barras, quando maiores que os símbolos, representam o erro padrão da diferença. 
(c)

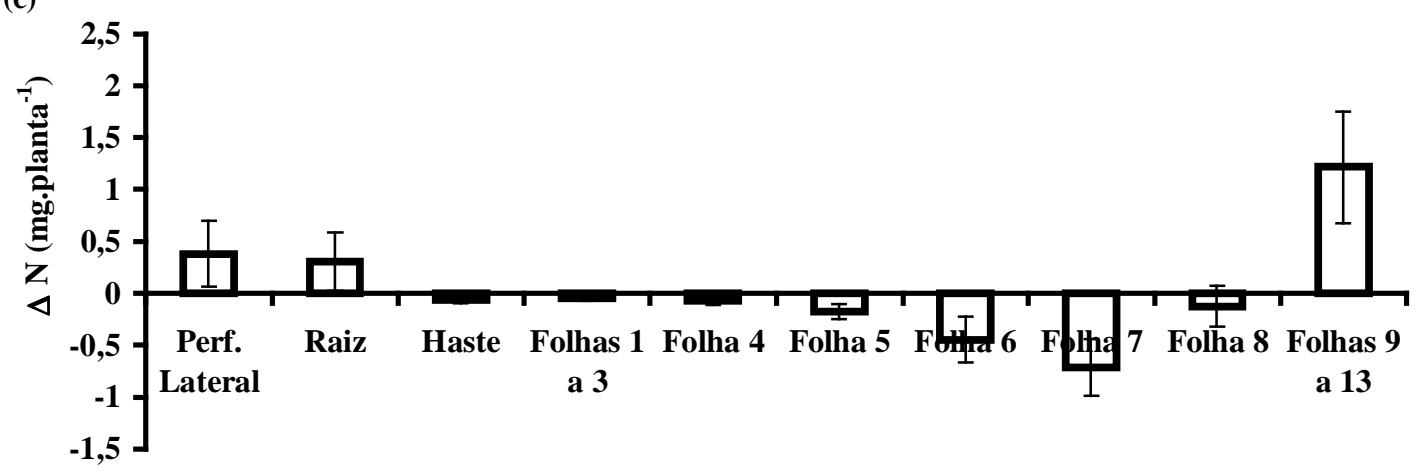

(d)

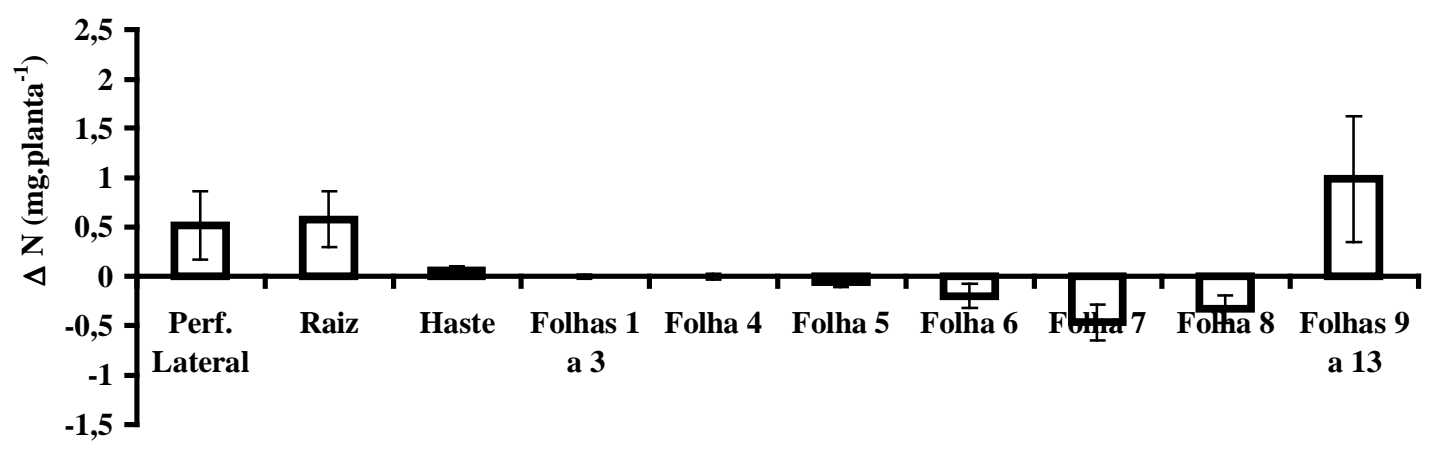

Figura 13 - Variação no conteúdo de $\mathrm{N}$ total de partes da planta de capim Tanzânia: (a) diferença entre a primeira e a segunda coleta do tratamento $+\mathrm{N}$; (b) diferença entre a segunda e a terceira coleta do tratamento $+\mathrm{N}$; (c) diferença entre a primeira e a segunda coleta do tratamento zero N; (d) diferença entre a segunda e a terceira coleta do tratamento zero N. As barras, quando maiores que os símbolos, representam o erro padrão da diferença. 

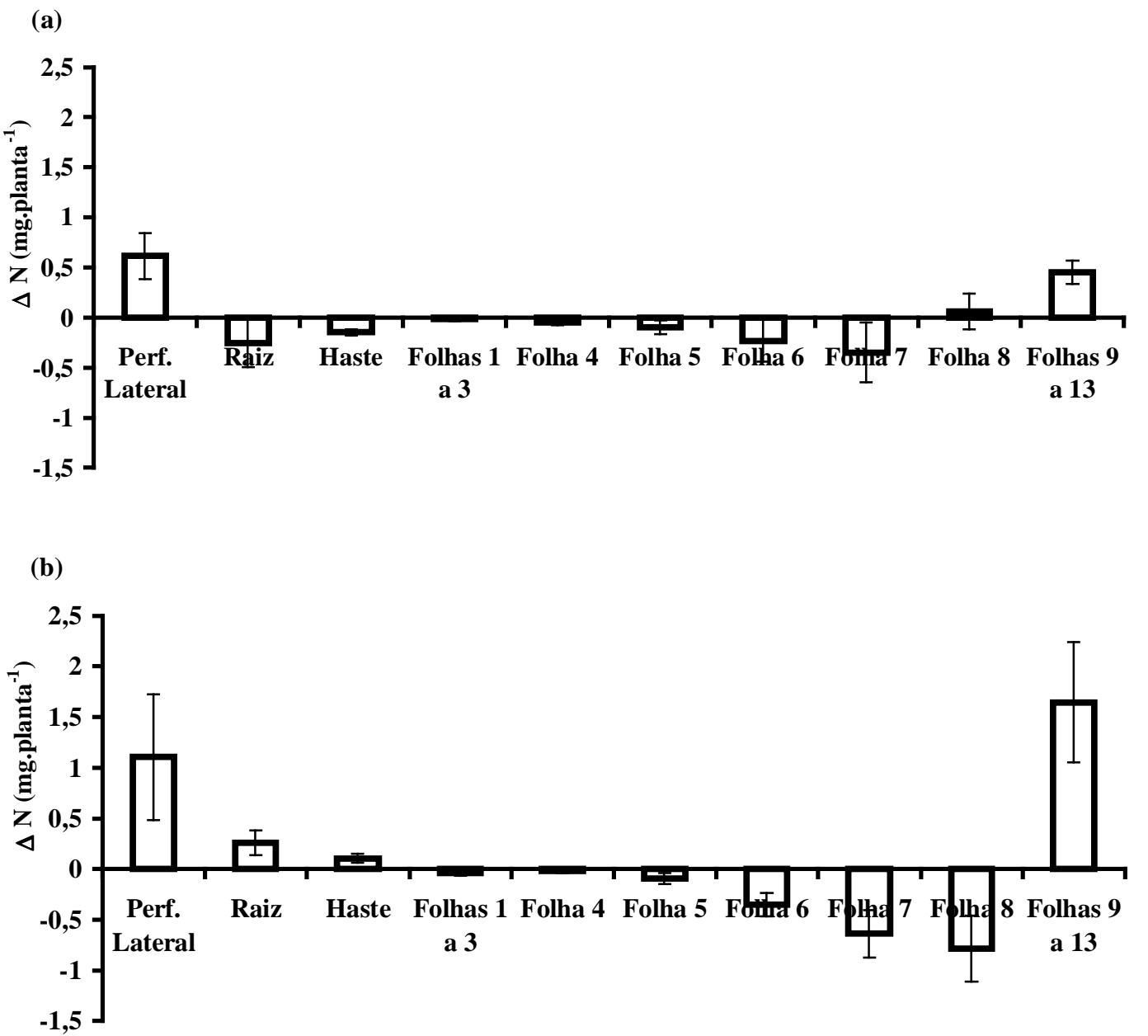

Figura 14 - Variação no conteúdo de N não marcado (mobilização) de partes da planta de capim Tanzânia do tratamento +N: (a) diferença entre a primeira e a segunda coleta; (b) diferença entre a segunda e a terceira coleta. As barras, quando maiores que os símbolos, representam o erro padrão da diferença. 
(a)

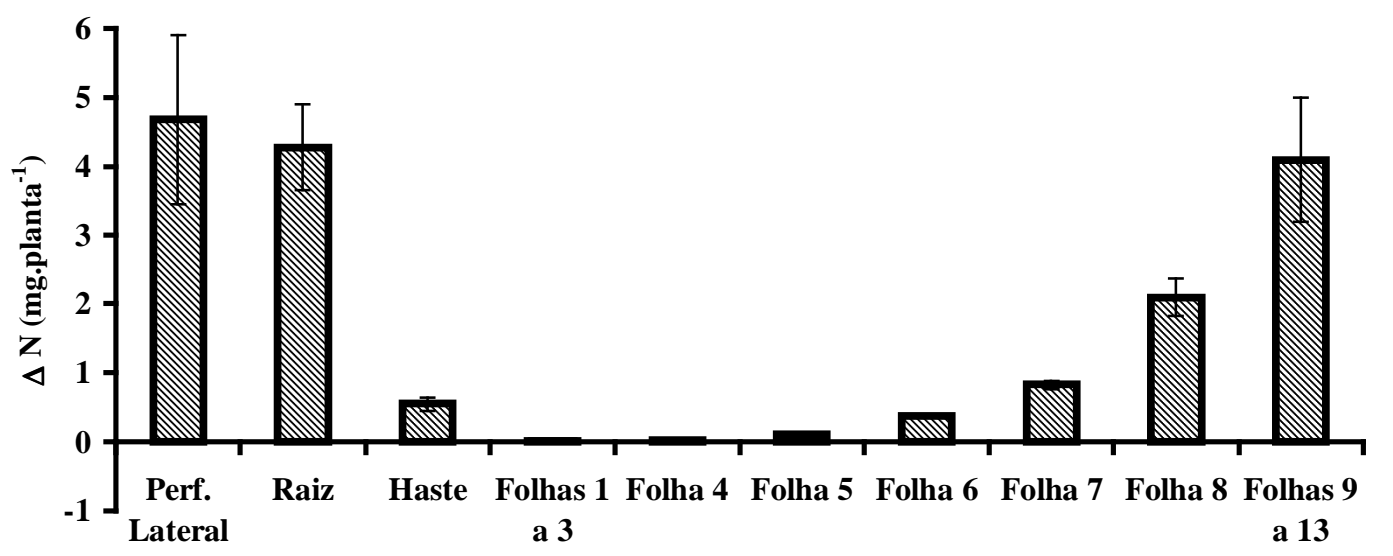

(b)

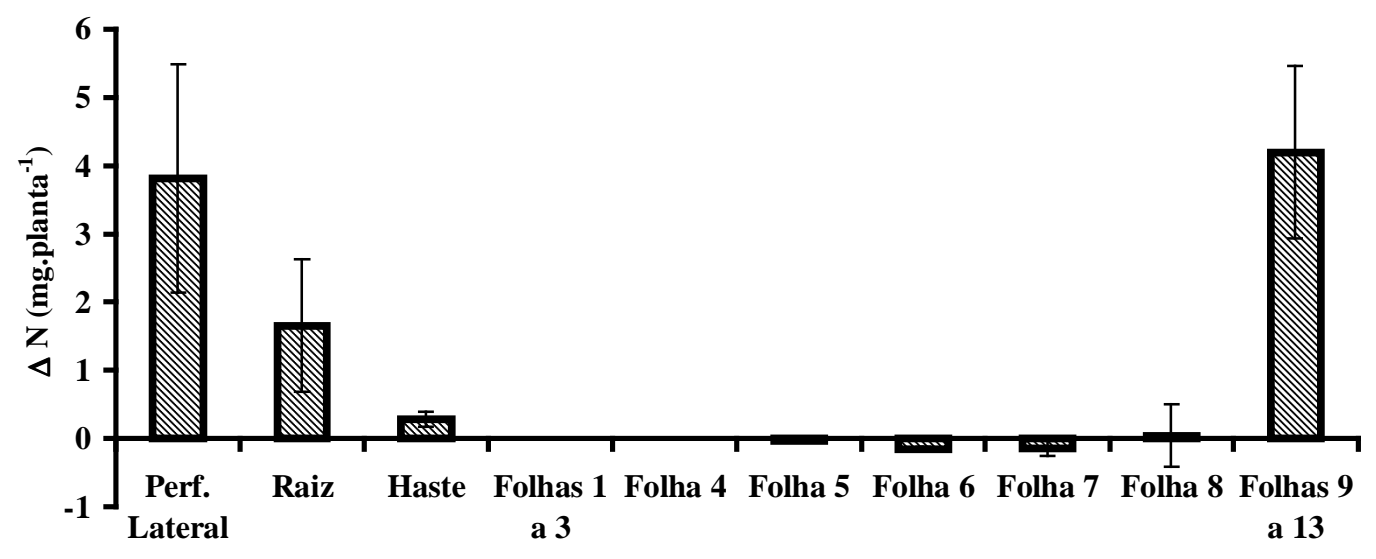

Figura 15 - Variação no conteúdo de N marcado (absorção) de partes da planta de capim Tanzânia do tratamento $+\mathrm{N}$ : (a) diferença entre a primeira e a segunda coleta; (b) diferença entre a segunda e a terceira coleta. As barras, quando maiores que os símbolos, representam o erro padrão da diferença. 
Tanto no tratamento $+\mathrm{N}$ quanto no Zero $\mathrm{N}$, o conteúdo de nitrogênio total aumentou nos perfilhos laterais, nas raízes e nas folhas em expansão ao longo das coletas (Figuras 13a, 13b, 13c e 13d).

Para ambos os tratamentos, as folhas em expansão parecem ser o dreno mais forte, recebendo $41 \%(+\mathrm{N})$ e $55 \%$ (zero $\mathrm{N}$ ) do total de nitrogênio mobilizado e/ou absorvido entre a primeira e a terceira coleta. No tratamento $+\mathrm{N}$, os perfilhos laterais receberam $36 \%$, as raízes $21 \%$ e as hastes $3 \%$ do nitrogênio, enquanto no tratamento zero $\mathrm{N}$ o restante do nitrogênio foi distribuído apenas entre os perfilhos laterais (23\%) e raízes (22\%).

Para o tratamento $+\mathrm{N}$, entre as duas primeiras coletas, o nitrogênio não marcado foi remobilizado das folhas de idade média, principalmente as folhas 6 e 7, e das raízes e hastes para os perfilhos laterais e folhas em expansão (folhas 9 a 13) (Figura 14a). A mobilização de nitrogênio não marcado para os perfilhos laterais e folhas em expansão continuou entre a segunda e terceira coletas. Além disso, o conteúdo de nitrogênio não marcado também aumentou nas raízes e hastes (Figura 14b). Considerando o período entre a primeira e a terceira coleta, $55 \%$ do nitrogênio mobilizado foi para as folhas em expansão e $45 \%$ para os perfilhos laterais.

A maior porcentagem de nitrogênio não marcado enviado para o sistema radicular no tratamento zero $\mathrm{N}$ em relação ao $+\mathrm{N}$ é decorrente, portanto, da redução do nitrogênio enviado para os perfilhos laterais. Lemaire \& Millard (1999) sugerem que a relação C:N no substrato da reserva de raízes e parte aérea seja um sinal importante na regulação do metabolismo das plantas. Para Carex rostrata foi observado que apenas os perfilhos com alta disponibilidade de compostos nitrogenados em relação aos carboidratos iniciavam um perfilho novo (Saarinen \& Haansuu, 2000). No presente experimento, o número de perfilhos laterais iniciados no capim Tanzânia foi maior para o tratamento $+\mathrm{N}$ (dados não apresentados). A relação entre compostos nitrogenados e carboidratos não foi determinada, no entanto, o aumento da massa seca das plantas do tratamento zero $\mathrm{N}$ sem o concomitante aumento do conteúdo de $\mathrm{N}$ sugere que a relação C:N destas plantas aumentou ao longo das coletas. Desta forma, a redução da porcentagem de $\mathrm{N}$ enviada para o desenvolvimento de perfilhos laterais pode estar ligada ao menor perfilhamento e à redução da relação C:N.

A estratégia de sobrevivência adotada pelas plantas diante da deficiência de nitrogênio depende da espécie. Erley et al. (2000) observaram que plantas de azevém utilizavam a reserva nitrogenada para o desenvolvimento de perfilhos laterais apenas quando o nível de fornecimento 
de nitrogênio era elevado, enquanto a festuca, apesar de aumentar a porcentagem de nitrogênio enviada para o sistema radicular, continuava enviando boa parte do nitrogênio para os perfilhos laterais. Os autores concluíram que a estratégia do azevém é tentar compensar a redução do nível de nitrogênio com o aumento do desenvolvimento do sistema radicular e, consequentemente, da capacidade de absorção de nutrientes, enquanto a festuca tenta sobreviver através da formação de perfilhos novos que têm menor ritmo de crescimento.

No capim Tanzânia, a quantidade de nitrogênio não marcado enviada para o sistema radicular foi maior no tratamento zero $\mathrm{N}$, porém as folhas em expansão continuaram a ser o dreno mais forte na planta e parte do nitrogênio continuou sendo utilizado para o desenvolvimento dos perfilhos laterais. A estratégia de crescimento do capim Tanzânia parece, portanto, ser diferente das descritas para o azevém e a festuca, pois este investe a maior parte da sua reserva no desenvolvimento de área foliar.

O capim Tanzânia é uma planta cespitosa com altura média de 1,3 m (Savidan et al. 1990). A porcentagem de ocupação da superfície do solo em áreas de gramíneas cespitosas é, geralmente, baixa. Martha Jr. (1999), por exemplo, determinou que em uma área de capim elefante as touceiras ocupavam apenas de 40 a $50 \%$ da superfície do solo. A redução do desenvolvimento da parte aérea nessas áreas pode ser prejudicial à essas plantas, pois abre espaço para o aparecimento de plantas invasoras. Desta forma, a vantagem de se investir a maior parte da reserva no desenvolvimento de folhas parece ser a diminuição da chance de desenvolvimento de plantas novas nas áreas circunvizinhas, reduzindo, portanto, a competição pelo fator de crescimento limitante.

Esta estratégia, no entanto, coloca a maior parte da reserva da planta em um órgão facilmente coletado por corte ou pastejo. Este talvez seja uma dos motivos pelos quais o capim Tanzânia não sobrevive a pastejos freqüentes e intensos em áreas de baixa fertilidade.

No experimento desenvolvido por Erley et al. (2000), nos dois níveis de fornecimento de $\mathrm{N}$ testados, as raízes de festuca e azevém foram dreno de nitrogênio. Em um outro experimento, onde Bausenwein et al. (2001a) compararam Festuca rubra e Agrostis capillaris, as raízes não contribuíram para o desenvolvimento de tecidos novos, havendo um pequeno aumento na quantidade de $\mathrm{N}$ mobilizado para as raízes ao longo do período experimental. Bausenwein et al. (2001b), por outro lado, observou que em Rumex acetosa L. a raiz principal foi a fonte mais importante de nitrogênio, sendo que, durante a fase reprodutiva, algum nitrogênio foi mobilizado 
também das folhas e raízes secundárias. Para o capim Tanzânia, as raízes foram dreno de nitrogênio no tratamento zero $\mathrm{N}$ (Figura 13c e 13d), porém no tratamento $+\mathrm{N}$ o padrão de comportamento não é claro (Figuras 14a e 14b). Em nenhum desses experimentos, as raízes novas e velhas foram separadas, o que talvez justifique os resultados conflitantes.

A mobilização de nitrogênio não marcado foi maior entre a segunda e terceira coletas do que entre as duas primeiras (Figuras 14a e 14b). O capim Tanzânia é capaz de manter cerca de 5 folhas verdes por perfilho (Santos, 1997; Pedreira et al. 2001), sendo que o comprimento das folhas aumenta com o nível de inserção até que um valor máximo seja atingido (Wilson, 1976; Carvalho et al., 1999b). As Figura 13c, 13d, 14a e 14b mostram que as folhas de idade média (folhas mais novas completamente expandidas) são as principais fontes de nitrogênio não marcado. Walker et al. (2001) apresentaram algumas evidências de que a taxa de mobilização de nitrogênio depende do tamanho e do tipo de reserva nitrogenada da planta. Desta forma, é provável que o aumento da mobilização de $\mathrm{N}$ não marcado ao longo das coletas seja uma consequiência do aumento da quantidade de $\mathrm{N}$ disponível para mobilização, uma vez que o tamanho das folhas "fonte" aumenta (ex: a partir da segunda coleta a folha 8 se tornou a principal fonte de $\mathrm{N}$ no tratamento $+\mathrm{N}$ ).

$\mathrm{O}$ nitrogênio absorvido pelas plantas do tratamento $+\mathrm{N}$ foi direcionado, principalmente, para perfilhos laterais, raízes e folhas em expansão (Figuras 15a e 15b). Entre as duas primeiras coletas, o conteúdo de ${ }^{15} \mathrm{~N}$ aumentou nas folhas 6 a 8 , ficando estável nessas partes da planta entre a segunda e terceira coletas.

Entre a primeira e a segunda coleta, no tratamento $+\mathrm{N}$, houve entrada de nitrogênio marcado ao mesmo tempo em que houve saída de nitrogênio não marcado das raízes, hastes e folhas 6 e 7 (Figuras 14a, 14b, 15a e 15 b). Bausenwein et al. (2001b) observaram que o conteúdo de nitrogênio de reserva decresceu continuamente até um pico mínimo durante o florescimento ao mesmo tempo em que houve entrada de nitrogênio absorvido na raiz principal de Rumex acetosa. Nesse caso, o nitrogênio proveniente de absorção radicular não foi suficiente para compensar a perda de nitrogênio de reserva e o conteúdo de $\mathrm{N}$ total diminuiu. Os resultados do presente experimento mostram que para o capim Tanzânia a entrada de nitrogênio marcado compensou totalmente a exportação de $\mathrm{N}$ não marcado, havendo, em alguns casos, aumento do conteúdo de $\mathrm{N}$ total. 
A ocorrência concomitante de importação e exportação de nitrogênio em alguns órgãos pode ser decorrente de diferenças no estádio de desenvolvimento de suas células. Em nenhum destes experimentos foi feita a separação entre raízes novas e velhas. Além disso, a folha em expansão de uma gramínea apresenta todos os estádios de desenvolvimento, desde o mais imaturo na região meristemática até o totalmente funcional e diferenciado na ponta (Dale, 1992). É possível, portanto, que a importação e exportação líquida de nitrogênio marcado e não marcado ocorram em partes diferentes do mesmo órgão.

A absorção radicular foi a principal fonte de nitrogênio para o desenvolvimento das plantas de capim Tanzânia (Tabelas 17, 18 e 19). A maior participação do nitrogênio proveniente de mobilização foi observada para o crescimento de folhas em expansão entre a segunda e terceira coletas (28,2 \%). Bausenwein et al. (2001b) observaram que em Rumex acetosa a maior porcentagem de nitrogênio proveniente de mobilização nos tecidos em crescimento foi de $23 \%$. Já para Festuca rubra e Agrostis capillaris, Bausenwein et al. (2001a) observaram que o nitrogênio proveniente de mobilização representou, respectivamente, 70 e $82 \%$ do nitrogênio total utilizado para o desenvolvimento de tecidos novos no início da primavera, reduzindo para 34 e $45 \%$ no início do verão.

Tabela 17. Uso relativo de nitrogênio proveniente da absorção radicular e da remobilização nos principais drenos de nitrogênio do capim Tanzânia entre a primeira e segunda coletas.

\begin{tabular}{lccc}
\hline \multicolumn{1}{c}{ Parte da planta } & $\Delta \mathrm{N}$ total (mg/planta) & Absorção (\%) & Remobilização (\%) \\
\hline Perf. Lateral & 5,2922 & 88,4 & 11,6 \\
Raiz & 4,0204 & 106,3 & $-6,3$ \\
Folha em expansão (8-13) & 6,7060 & 92,3 & 7,7 \\
\hline
\end{tabular}


Tabela 18. Uso relativo de nitrogênio proveniente da absorção radicular e da remobilização nos principais drenos de nitrogênio do capim Tanzânia entre a segunda e terceira coletas.

\begin{tabular}{lccc}
\hline \multicolumn{1}{c}{ Parte da planta } & $\Delta \mathrm{N}$ total (mg/planta) & Absorção (\%) & Remobilização (\%) \\
\hline Perf. Lateral & 4,9179 & 77,6 & 22,4 \\
Raiz & 1,9164 & 86,5 & 13,5 \\
Folha em expansão (9-13) & 5,8431 & 71,8 & 28,2 \\
\hline
\end{tabular}

Tabela 19. Uso relativo de nitrogênio proveniente da absorção radicular e da remobilização nos principais drenos de nitrogênio do capim Tanzânia entre a primeira e terceira coletas.

\begin{tabular}{lccc}
\hline Parte da planta & $\Delta \mathrm{N}$ total (mg/planta) & Absorção (\%) & Remobilização (\%) \\
\hline Perf. Lateral & 10,2101 & 83,2 & 16,8 \\
Raiz & 5,9368 & 99,9 & 0,1 \\
Folha em expansão (8-13) & 11,8116 & 88,4 & 11,6 \\
\hline
\end{tabular}

Apesar de alguns trabalhos mostrarem efeito significativo da desfolha sobre a importância relativa da mobilização em relação à absorção de N (Kim et al, 1991) e dos resultados obtidos no presente experimento seram referentes à plantas intactas, estes mostram claramente que o fornecimento de $\mathrm{N}$ via solo é importante para o desenvolvimento adequado do capim Tanzânia, e que informações sobre fertilização nitrogenada são fundamentais para o adequado manejo deste cultivar. 


\section{CONCLUSÕES}

A renovação de perfilhos no capim Tanzânia foi maior nas áreas submetidas a alta intensidade de pastejo.

Nenhuma geração de perfilhos se destacou em termos de participação na massa de forragem total, sendo que sua importância relativa dependeu da intensidade de pastejo. Desta forma, não é possível programar o manejo do capim Tanzânia com base nas caraterísticas de uma única geração.

A porcentagem de folhas dependeu, principalmente, do estádio de desenvolvimento do capim e do ciclo de pastejo, embora haja uma tendência das gerações mais novas há apresentarem maior porcentagem de folhas em relação às mais velhas. Não é possível, portanto, controlar o desenvolvimento das hastes através de cortes estratégicos que visem a eliminar determinadas gerações de perfilhos.

A participação das gerações de perfilhos na produção de hastes dependeu da intensidade do pastejo: quando este foi mais intenso, a participação das gerações mais novas foi maior que no pastejo mais leve. A digestibilidade "in vitro" da matéria orgânica das gerações de perfilhos diminuiu com o avanço da idade e, de modo geral, foi maior nas áreas submetidas a alta intensidade de pastejo. Estratégias de manejo que promovam uma maior renovação de perfilhos a partir do mês de fevereiro parecem, portanto, boas alternativas para se reduzir os efeitos negativos do florescimento em pastagens de capim Tanzânia. No entanto, é preciso observar seus efeitos sobre a produção animal e a perenidade do pasto.

No capim Tanzânia, os principais drenos por nitrogênio, proveniente tanto de absorção quanto de mobilização, foram as folhas em expansão, seguidas dos perfilhos laterais e das raízes. A supressão do fornecimento de $\mathrm{N}$ não alterou este padrão de distribuição. As folhas mais novas completamente expandidas representaram a principal fonte de nitrogênio para mobilização. Devido à alocação da maior parte do nitrogênio em órgão facilmente colhidos através da desfolha, 
a adoção de pastejos muito frequentes e intensos, principalmente em áreas de baixa fertilidade, pode ser prejudicial à rebrota e à perenidade do pasto. Desta forma, para a determinação de estratégias de manejo que a visem reduzir os efeitos negativos do desenvolvimento das hastes através da maior renovação da população de perfilhos, são necessários estudos que verifiquem a dinâmica interna de nitrogênio em plantas submetidas a desfolha, assim como os efeitos deste processo sobre a perenidade do pasto.

A absorção radicular foi a principal fonte de N, demonstrando a importânica de mais estudos sobre o desenvolvimento do sistema radicular e sobre a dinâmica de nitrogênio no sistema solo-planta. 


\section{REFERÊNCIAS BIBLIOGRÁFICAS}

ADAMS, S.R.; PEARSON, S.; HADLEY, P. Improving quantitative flowering models through a better understanding of the phases of photoperiod sensitivity. Journal of Experimental Botany, v.52, p.655-662, 2001.

AERTS, R. Interspecific competition in natural plant communities: mechanisms, trade-offs and plant-soil feedback. Journal of Experimental Botany, v.50, p.29-37, 1999.

AGREDA, O.; CUANY, R.L. Efectos fotoperiódicos y fecha de floración en jaraguá (Hyparrhenia rufa). Turrialba, v.12, p.146-149, 1962.

AGUlHON, R.A.; JOBIM, C.C.; CANTO, M.W.; CECATO, U.; DAMASCENO, J.C.; SANTOS, G.T. Análise econômica da utilização de uma pastagem de capim tanzânia (Panicum maximum Jacq.), em pastejo, no ano do estabelecimento. In: REUNIÃO ANUAL DA SOCIEDADE BRASILEIRA DE ZOOTECNIA, 38., Piracicaba, 2001. Anais. Piracicaba: SBZ, 2001. p.90-92.

ALCÂNTARA, V.B.G.; ALMEIDA, A.R.P; GHISI, O.M.A.A. Estudos fisiológicos de seis cultivares de Panicum maximum Jacq. Boletim da Indústria Animal, v.42, p.199-208, 1985.

ANDRADE, J.B. Estudo comparativo de 3 capins da espécie Panicum maximum Jacq. (colonião, tobiatã e K-187-B). Piracicaba, 1987. 133p. Dissertação (Mestrado) - Escola Superior de Agricultura “Luiz de Queiroz”, Universidade de São Paulo.

AUDA, H.; BLASER, R.E.; BROWN, R.H. Tillering and carbohydrate contents of orchardgrass as influenced by environmental factors. Crop Science, v.6, p.139-143, 1966.

AUSTIN, R.B.; BINGHAM, R.D.; BLACKWELL, R.D.; EVANS, L.T.; FORD, M.A.; MORGAN, C.L.; TAYLOR, M. Genetic improvement in winter wheat yields since 1900 and associated physiological changes. Journal of Agricultural Science, v.94, p.675-689, 1980. 
AVICE, J.C.; OURRY, A.; LEMAIRE, G.; BOUCAUD, J. Nitrogen and carbon flows estimated by ${ }^{15} \mathrm{~N}$ and ${ }^{13} \mathrm{C}$ pulse-chase labelling during regrowth of alfafa. Plant Physiology, v.112, p.281-290, 1996.

BALSALOBRE, M. A. A. Desempenho de vacas em lactação sob pastejo rotacionado de capimelefante (Pennisetum purpureum Schum.) Piracicaba, 1996. 139p. Dissertação (Mestrado) Escola Superior de Agricultura "Luiz de Queiroz”, Universidade de São Paulo.

BARBOSA, M.A.A.F.; DAMASCENO, J.C.; CECATO, U.; SAKAGUTI, E.S. Influência da eliminação do meristema apical no aparecimento de perfilhos, em quatro cultivares de Panicum maximum Jacq. In: REUNIÃO ANUAL DA SOCIEDADE BRASILEIRA DE ZOOTECNIA, 33., Fortaleza, 1996. Anais. Fortaleza:SBZ, 1996a. p.104-105.

BARBOSA, M.A.A.F.; DAMASCENO, J.C.; CECATO, U.; SAKAGUTI, E.S. Estudo de perfilhamento em 4 cultivares de Panicum maximum Jacq. submetidos à duas alturas de corte. In: REUNIÃO ANUAL DA SOCIEDADE BRASILEIRA DE ZOOTECNIA, 33., Fortaleza, 1996. Anais. Fortaleza:SBZ, 1996b. p.106-109.

BARBOSA, M.A.A.F.; CECATO, U.; ONORATO, W.M.; BERALDO, J.A.; YANAKA, F.Y.; BERTOLASSI, J.R.; PETERNELLI, M. Efeito do N e do intervalo entre cortes no número de perfilhos do capim mombaça (Panicum maximum Jacq. cv. Mombaça). In: REUNIÃO ANUAL DA SOCIEDADE BRASILEIRA DE ZOOTECNIA, 35., Botucatu, 1998. Anais. Botucatu: SBZ, 1998. p.99-101.

BARBOSA, M.A.A.F.; CECATO, U.; ONORATO, W.M.; BERALDO, J.A.; YANAKA, F.Y.; BERTOLASSI, J.R.; PETERNELLI, M. Efeito do N e do intervalo entre corte no número de perfilhos do capim mombaça (Panicum maximum Jacq. cv. Mombaça) (compact disc). In: REUNIÃO ANUAL DA SOCIEDADE BRASILEIRA DE ZOOTECNIA, 36., Porto Alegre, 1999. Anais. Porto Alegre: SBZ, 1999.

BARTHRAM, G.T.; GRANT, S.A. Defoliation of ryegrass-dominated swards by sheep. Grass and Forage Science, v.39, p.211-219, 1984.

BAUSENWEIN, U.; MILLARD, P.; RAVEN, J.A. Remobilized old-leaf nitrogen predominates for spring growth in two temperate grasses. New Phytologist, v.152, p.283-290, 2001a.

BAUSENWEIN, U.; MILLARD, P.; THORNTON, B.; RAVEN, J.A. Seasonal nitrogen storage and remobilization in the forb Rumex acetosa. Functional Ecology, v.15, p.370-377, 2001b. 
BIRCHAM, J.S.; HODGSON, J. The influence of sward condition on rates of herbage growth and senescence in mixed swards under continuous stocking management. Grass and Forage Science, v.38, p.323-331, 1983.

BLAIKIE, S.J.; MASON, W.K. Correlation of growth of the root and the shoot systems of white clover after a period of water shortage and/or defoliation. Australian Journal of Agricultural Research, v.41, p.891-900, 1990.

BLAKELEY, S.D.; DENNIS, D.T. Molecular approaches to the manipulation of carbon allocation in plants. Canadian Journal of Botany, v.71, p.765-778, 1993.

BOERMA, H.R.; ASHLEY, D.A. Canopy photosynthesis and seed-fill duration in recently developed soybean cultivars and selected plant introductions. Crop Science, v.28, n. 1, p.137$140,1988$.

BOWMAN, W.D.; TURNER, L. Photosynthetic sensitivity to temperature in populations of two C4 bouteloa (Poaceae) species native to diferent altitudes. American Journal of Botany, v.80, p.369-374, 1993.

BRÂNCIO, P.A.; EUCLIDES, V.P.B.; NASCIMENTO Jr., D.; REGAZZI, A.J.; ALMEIDA, R.G.; FONSECA, D.M. Consumo de matéria seca e ganho de peso por bovinos em pastejo na avaliação de cultivares de Panicum maximum Jacq. In: REUNIÃO ANUAL DA SOCIEDADE BRASILEIRA DE ZOOTECNIA, 38., Piracicaba, 2001. Anais. Piracicaba: SBZ, 2001. p.224-225.

BRÂNCIO, P.A.; NASCIMENTO Jr., D.; EUCLIDES, V.P.B.; REGAZZI, A.J.; ALMEIDA, R.G.; FONSECA, D.M. Avaliação de três cultivares de Panicum maximum Jacq. sob pastejo. 5 - tamanho de bocado (compact disc). In: REUNIÃO ANUAL DA SOCIEDADE BRASILEIRA DE ZOOTECNIA, 37., Viçosa, 2000. Anais. Viçosa: SBZ, 2000.

BRISKE, D.D. Strategies of plant survival in grazing systems: a functional interpretation. In. HODGSON, J.; ILLIUS, A.W. (Ed.) The ecology and management of grazing systems. Wallingford: CAB International, 1996. cap.2, p.37-68.

BULLOCK, J.M. Plant competition and population dynamics. In: HODGSON, J.; ILLIUS, A.W. (Ed.) The ecology and management of grazing systems. Wallingford: CAB International, 1996. cap.3, p.69-100.

CALOIN, M. Analysis of dry matter partitioning in Dactylis glomerata during vegetative growth using a carbon budget model. Annals of Botany, v.73, p.665-669, 1994. 
CARVALHO, C.A.B. Padrões demográficos de perfilhamento e acúmulo de forragem em pastagens de Cynodon spp. manejadas em quatro intensidades de pastejo. Piracicaba, 2000. 96p. Dissertação (Mestrado) - Escola Superior de Agricultura "Luiz de Queiroz", Universidade de São Paulo.

CARVALHO, D.D.; MATTHEW, C.; BARIONI, L.G. Participação da matéria seca e perfilhamento em três cultivares de $P$. maximum (Jacq.) submetidos a dois níveis de desfolhação (compact disc). In: REUNIÃO ANUAL DA SOCIEDADE BRASILEIRA DE ZOOTECNIA, 36., Porto Alegre, 1999a. Anais. Porto Alegre: SBZ, 1999a.

CARVALHO, D.D.; MATTHEW, C.; HODGSON, J. Leaf morphogenesis and site filling in the establishment period in three Guinea grass (Panicum maximum) cultivars. In: ANNUAL CONFERENCE OF THE AGRONOMY SOCIETY OF NEW ZEALAND, 29., Albany, 1999. Proceedings. Albany: Agronomy Society of New Zealand, 1999b. p.107-114.

CASAL, J.J.; SANCHEZ, R.A.; GIBSON, D. The significance of changes in the red/far-red ratio, associated with either neighbour plants or twilight, for tillering in Lolium multiflorum Lam. New Phytologist, v.116, p.565-572, 1990.

CASPER, B.B.; CAHILL FILHO, J.F.; HYATT, L.A. Above-ground competition does not alter biomass allocated to roots in Abutilon theophrasti. New Phytologist, v.140, p.231-238, 1998.

CECATO, U.; MARCO, A.A.F.B; SAKAGUTI, E.S.; DAMASCENO, J.C.; SUZUKI, E.; MEURER, F. Avaliação de cultivares de Panicum maximum Jacq. In: REUNIÃO ANUAL DA SOCIEDADE BRASILEIRA DE ZOOTECNIA, 34., Fortaleza, 1996. Anais. Fortaleza: SBZ, 1996. p.403-406

CHAPMAM, D.F; CLARK, D.A.; LAND, C.A.; DYMOCK, N. Leaf and tiller growth of Lolium perenne and Agrostis spp. and leaf appearance rates of Trifolium repens in set-stocked and rotationally grazed hill pastures. New Zealand Journal of Agricultural Research, v.26, p.159-168, 1983.

COELHO, E.M.; CECATO, U.; BARBOSA, M.A.A.F.; YANAKA, F.Y. Características do perfilhamento em quatro cultivares de Panicum maximum Jacq. (compact disc). In: REUNIÃO ANUAL DA SOCIEDADE BRASILEIRA DE ZOOTECNIA, 36., Porto Alegre, 1999. Anais. Porto Alegre: SBZ, 1999. 
COLVILL , K.E.; MARSHALL, C. Tiller dynamics and assimilate partitioning in Lolium perenne with particular reference to flowering. Annals of Applied Biology, v.104, p.543$557,1984$.

CORSI, M. Effects of nitrogen rates and harvesting intervals on dry matter production, tillering and quality of the tropical grass Panicum maximum, Jacq. Ohio, 1984. 125p. Tese (Ph.D)The Ohio State University.

CORSI, M. Pastagens de alta produtividade. In: SIMPÓSIO SOBRE MANEJO DA PASTAGEM, 8., Piracicaba, 1986. Anais. Piracicaba: FEALQ, 1986. p.499-512.

CORSI, M. Manejo de plantas forrageiras do gênero Panicum. In: SIMPÓSIO SOBRE MANEJO DA PASTAGEM, 9., Piracicaba, 1988. Anais. Piracicaba: FEALQ, 1988. p.5776.

COSTA, C.; FAVORETTO, V.; MALHEIROS, E.B. Estudo da variação na estrutura da vegetação de duas cultivares de Panicum maximum Jacq. (colonião e tobiatã) submetidas a diferentes tipos de manejo. 1. Produção e densidade de perfilhos e de matéria seca. Pesquisa Agropecuária Brasileira, v.27, n.1, p.131-142, 1992.

COSTA, N.L.; TOWNSEND, C.R.; MAGALHÃES, J.A.; PEREIRA, R.G.A. Avaliação agronômica sob pastejo de Panicum maximum cv. Tanzânia (compact disc). In: REUNIÃO ANUAL DA SOCIEDADE BRASILEIRA DE ZOOTECNIA, 37., Viçosa, 2000. Anais. Viçosa: SBZ, 2000.

COUGHENOUR, M.B.; McNAUGHTON, S.J.; WALLACE, L.L. Responses of an african tallgrass (Hyparrhenia filipendula Stapf.) to defoliation and limitations of water and nitrogen. Oecologia, v.68, p.80-86, 1985.

CRAUFURD, P.Q.; FLOWER, D.J.; PEACOCK, J.M. Effect of heat and drought stress on sorghum (Sorghum bicolor). I. Panicle development and leaf appearance. Experimental Agriculture, v.29, p.61-76, 1993.

CULVENOR, R.A. Observations on tillering in cultivars of Phalaris under rotational grazing in a year with a summer-autumn drought. Australian Journal of Agricultural Research, v.48, p.467-476, 1997.

DALE, J.E. How do leaves grow? Advances in cell and molecular biology are unrevealing some of the mysteries of leaf development. Bioscience, v.42, p.423-432, 1992. 
DAVIES, A. Carbohydrates levels and regrowth in perennial rye-grass. Journal of Agricultural Science, v.65, p.213-221, 1965.

DAVIES, A. Tissue turnover in the sward. In: DAVIES, A.; BAKER, R.D.; GRANT, S.A.; LAIDLAW, A.S. (Ed.) Sward measurement handbook. Reading: The British Grassland Society, 1993. cap.9, p.183-216.

DEINUM, B.; SULASTRI, R.D.; ZEINAB, M.H.J.; MAASSEN, A. Effects of light intensity on growth, anatomy and forage quality of two tropical grasses (Brachiaria brizantha and Panicum maximum var. trichoglume). Netherlands Journal of Agricultural Science, v.44, p.111-124, 1996.

DeLUCIA, E.H.; HECKATHORN, S.A.; DAY, T.A. Effects of soil temperature on growth, biomass allocation and resource acquisition of Andropogon gerardii Vitman. New Phytologist, v.120, p.543-549, 1992.

DEREGIBUS, V.A.; SANCHEZ, R.A.; CASAL, J.J.; TRLICA, M.J. Tillering responses to enrichment of red light beneath the canopy in a humid natural grassland. Journal of Applied Ecology, v.22, p.199-206, 1985.

DIRVEN, J.G.P.; VAN SOEST, L.J.M.; WIND, K. The influence of photoperiod on head formation in some Brachiaria species and Chloris gayana cv. Masaba. Netherlandas Journal of Agricultural Science, v.27, p.48-59, 1979.

DYER, M.I.; ACRA, M.A.; WANG, G.M.; COLEMAN, D.C.; FRECKMAN, D.W.; McNAUGHTON, S.J.; STRAIN, B.R. Source-sink carbon relations in two Panicum coloratum ecotypes in response to herbivory. Ecology, v.72,p.1472-1483, 1991.

EGLI, D.B.; ORF, J.H.; PFEIFFER, T.W. Genotypic variation for duration of seedfill in soybean. Crop Science, v.24, p.587-592, 1984.

ENGELS, C. Effect of root and shoot meristem temperature on shoot to root dry matter partitioning and the internal concentration of nitrogen and carbohydrates in maize and wheat. Annals of Botany, v.73, p.211-219, 1994.

ERICSON, T. Growth and shoot:root ratio of seedlings in relation to nutrient availability. Plant and Soil, v.168/169, p.205-214, 1995. 
ERLEY, G.S.; RADEMACHER, J.; KÜHBAUCH, W. Growth response of Lollium perenne L. and Festuca rubra L. seedlings to differing nitrogen nutrition. In: GENERAL MEETING OF THE EUROPEAN GRASSLAND FEDERATION, 18., Aalborg, 2000. Proceedings. Tjele: European Grassland Federation, 2000. p.397-399.

EUCLIDES, V.P.B.; MACEDO, M.C.M.; OLIVEIRA, M.P. Avaliação de cultivares de Panicum maximum em pastejo (compact disc). In: REUNIÃO ANUAL DA SOCIEDADE BRASILEIRA DE ZOOTECNIA, 36., Porto Alegre, 1999. Anais. Porto Alegre: SBZ, 1999a.

EUCLIDES, V.P.B.; THIAGO, L.R.L.S.; MACEDO, M.C.M.; OLIVEIRA, M.P. Consumo voluntário de forragem de três cultivares de Panicum maximum sob pastejo. Revista Brasileira de Zootecnia, v.28, p.1177-1185, 1999 b.

EVANS, L.T.; KING, R.W.; CHU, A.; MANDER, L.N.; PHARIS, R.P. Giberellin structure and florigenic activity in Lollium temulentum, a long-day plant. Planta, v.182, p.97-106, 1990.

FARRAR, J.F. Sinks - integral parts of a whole plant. Journal of Experimental Botany, v.47, p.1273-1279, 1996.

FAVORETTO, V.; TONINI JR., R.; REIS, R.A.; RODRIGUES, L.R.A. Efeito da altura e da frequiência de corte sobre a produção, composição bromatológica e vigor de rebrota do capim colonião. Pesquisa Agropecuária Brasileira, v.22, p.1279-1285, 1987.

FELIPPE, G.M. Effects of photoperiod, $\mathrm{GA}_{3}$ and $\mathrm{CCC}$ on flowering of Panicum maximum. Hoehnea, v.7, p.11-16, 1978.

FELIPPE, G.M. The flowering of tillers of Panicum maximum Jacq. Revista Brasileira de Botânica, v.2, p.87-90, 1979.

FERRARIS, R. The effect of photoperiod and temperature on the first crop and ratoon growth of Pennisetum purpureum Schum. Australian Journal of Agricultural Research, v.29, p.941950, 1978.

FERRARIS, R.; MAHONY, M.J.; WOOD, J.T. Effect of temperature and solar radiation on the development of dry matter and attributes of elephant grass (Pennisetum purpureum Schum.). Australian Journal of Agricultural Research, v.37, p.621-632, 1986.

FISHER, G.E.J.; DOWDESWELL, A.M. The effects of regrowth and maintenance height on a grass sward with a high density of tillers. Grass and Forage Science, v.51, p.464-468, 1995. 
FLORES, E.R.; LACA, E.A.; GRIGGS, T.C.; DEMMENT, M.W. Sward height and vertical morphological differentiation determine cattle bite dimensions. Agronomy Journal, v.85, p.527-532, 1993.

FORBES, T.D.A.; COLEMAN, S.W. Forage intake and ingestive behavior of cattle grazing old world bluestems. Agronomy Journal, v.85, p.808-816, 1993.

FORNI, S.; MICHEL FILHO, I.C.; FAVORETTO, V.; MALHEIROS, E.B. Efeito de estratégias de adubação com NPK sobre a produção, qualidade e estrutura das cultivares tanzânia e mombaça de Panicum maximum Jacq. (compact disc). In: REUNIÃO ANUAL DA SOCIEDADE BRASILEIRA DE ZOOTECNIA, 37., Viçosa, 2000. Anais. Viçosa: SBZ, 2000 .

FULKERSON, W.J.; SLACK, K. Leaf number as a criterion for determining defoliation time for Lollium perenne. 1. Effect of water-soluble carbohydrates and senescenece. Grass and Forage Science, v.49, p.373-377, 1994.

FULKERSON, W.J.; SLACK, K. Leaf number as a criterion for determining defoliation time for Lolium perenne. 1. Effect defoliation frequency and height. Grass and Forage Science, v.50, p.16-20, 1995.

GEIGER, D.R; KOCH, K.E.; SHIEH, W.J. Effect of environmental factors on whole plant assimilate partitioning and associate gene expression. Journal of Experimental Botany, v.47, p.1229-1238, 1996.

GENT, M.P.N.; KIYOMOTO, R.K. Assimilation and distribution of photosynthate in winter wheat cultivars differing in harvest index. Crop Science, v.29, p.120-125 1989.

GEORGE, J.R.; REIGH, G.S. Spring growth and tiller characteristics of switchgrass. Canadian Journal of Plant Science, v.67, p.167-174, 1987.

GIFFORD, R.M.; THORNE, J.H.; HITZ, W.D.; GIAQUINTA, R.T. Crop productivity and photoassimilate partitioning. Science, v.225, p.801-808, 1984.

GOMIDE, J.A.; OBEID, J.A.; RODRIGUES, L.R.A. Fatores morfofisiológicos de rebrota do capim-colonião (Panicum maximum). Revista da Sociedade Brasileira de Zootecnia, v.8, p.532-562, 1979.

GRANT, S.A.; BARTHRAM, G.T.; TORVELL, L.; KING, J.; SMITH, H.K. Sward management, lamina turnover and tiller population density in continuously stocked Lolium perenne-dominated swards. Grass and Forage Science, v.38, p.333-344, 1983. 
HAVELY, A.H. Handbook of flowering. Boca Raton: CRC Press, 1985. v.1, 568 p.

HAY, R.K.M.; WALKER, A.J. An introduction to the physiology of crop yield. Essex: Longman Scientific and Technical, 1989. 292p.

HERLING, V.R.; JANTALIA, C.P.; PIAZZA, C.; SUDA, C.H.; LUZ, P.H.C.; LIMA, C.G. Fisiologia de perfilhamento do capim mombaça (Panicum maximum Jacq. cv. Mombaça) sob pastejo. In: REUNIÃO ANUAL DA SOCIEDADE BRASILEIRA DE ZOOTECNIA, 35., Botucatu, 1998. Anais. Botucatu: SBZ, 1998. p.533-535.

HERLING, V.R.; SISTI, C.P.J.; LUZ, P.H.C.; LIMA, C.G.; RODRIGUES, L.R.A.; PIAZZA, C.; RUFATTO, J.C.; LEITA, D.M.O. Eliminação de meristema apical e perfilhamento do capim mombaça (Panicum maximum Jacq. cv. Mombaça) sob pastejo. In: SIMPÓSIO INTERNACIONAL “GRASSLAND ECOPHYSIOLOGY AND GRAZING ECOLOGY”, 1., Curitiba, 1999, Anais. Curitiba: UFPR, 1999. p.375-377.

HILLENSHEIM, A. Fatores que afetam o consumo e perdas de capim elefante (Pennisetum purpureum, Schum) sob pastejo. Piracicaba, 1988. 94p. Dissertação (Mestrado) - Escola Superior de Agricultura “Luiz de Queiroz”, Universidade de São Paulo.

HODGSON, J. Grazing management: science into practice. Essex: Longman Scientific \& Technical, 1990. 203p.

HOPKINS, W.G. Introduction to plant physiology. New York: John Wiley, 1995. 464p.

HOPKINSON, J.M.; ENGLISH, B.H. Spikelet population dynamics in seed crops of Panicum maximum 'Gatton'. Seed Science and Technology, v.10, p.379-403, 1982.

HUME, D.E. Leaf and tiller production of praire grass (Bromus willdenowii Kunth.) and two ryegrass (Lolium) species. Annals of Botany, v.67, p.111-121, 1991.

JANK, L. Melhoramento e seleção de variedades de Panicum maximum . In: SIMPÓSIO SOBRE MANEJO DA PASTAGEM, 12., Piracicaba, 1995. Anais. Piracicaba: FEALQ, 1995. p.21-58.

JANK, L.; SAVIDAN, Y.; SOUZA, M.T.; COSTA, J.G.C. Avaliação do germoplasma de Panicum maximum introduzido da África. 1. Produção forrageira. Revista da Sociedade Brasileira de Zootecnia, v.23, p.433-440, 1994.

JONES, M.B.; COLLET, B.; BROWN, S. Sward growth under cutting and continuous stocking management: sward canopy structure, tiller density and leaf turnover. Grass and Forage Science, v.37, p.67-73, 1982. 
KALAPOS, T.; BOOGAARD, R.; LAMBERS, H. Effect of soil drying on growth, biomass allocation and leaf gas exchange of two annual grass species. Plant and Soil, v.185, p.137149, 1996.

KIM, T.H.; OURRY, A.; BOUCAUD, J.; LEMAIRE, G. Changes in source-sink relationship for nitrogen during regrowth of lucerne (Medicago sativa L.) following removal of shoots. Australian Journal of Plant Physiology, v.18, p.593-602, 1991.

KING, R.K.; HILL, M.J.; WILLMS, W.D. Growth response of Festuca altaica, Festuca hallii, and Festuca campestris to temperature. Canadian Journal of Botany, v.73, p.1074-1080, 1995.

KING, R.W.; BLUNDELL, C.; EVANS, L.T. The behaviour of shoot apices of Lolium temulentum in vitro as the basis of an assay system for florigenic extracts. Australian Journal of Plant Physiology, v.20, p.337-348, 1993.

KORTE, C.J.; WATKIN, B.R.; HARRIS, W. Effects of the timing and intensity of spring grazing on reproductive development, tillering, and herbage production of perennial ryegrass dominant pasture. New Zealand Journal of Experimental Research, v.27, p.135-149, 1984.

KORTE, C.J.; WATKIN, B.R. Tillering in 'Grassland Nui' perennial ryegrass swards 1. Effect of cutting treatments on tiller appearance and longevity, relationship between tiller age and weight and herbage production. New Zealand Journal of Agricultural Research, v.28, p.437-447, 1985.

KORTE, C.J.; WATKIN, B.R.; HARRIS, W. Use of residual leaf area index and light interception as criteria for spring-grazing management of a ryegrass-dominant pasture. New Zealand Journal of Experimental Research, v.25, p.309-319, 1982.

LEMAIRE, G.; MILLARD, P. An ecophysiological approach to modelling resource fluxes in competing plants. Journal of Experimental Botany, v.50, p.15-28, 1999.

LONSDALE, W.M. The self-thinning rule: dead or alive? Ecology, v.71,p.1373-1388, 1990.

MARCELIS, L.F.M. Sink strength as a determinant of dry matter partitioning in the whole plant. Journal of Experimental Botany, v.47, p.1281-1291, 1996.

MARSCHNER, H.; KIRKBY, E.A.; CAKMAK, I. Effect of mineral nutritional status on shootroot partitioning of photoassimilates and cycling of mineral nutrients. Journal of Experimental Botany, v.47, p.1255-1263, 1996. 
MARSHALL, E.J.P. Some effects of annual applications of three growth-retarding compounds on the composition and growth of a pasture sward. Journal of Applied Ecology, v.25, p.619630, 1988.

MARTHA JR., G.B. Balanço ${ }^{15} \mathrm{~N}$ e perdas de amônia por volativização em pastagens de capim elefante. Piracicaba, 1999. 75 p. Dissertação (Mestrado) - Escola Superior de Agricultura “Luiz de Queiroz”, Universidade de São Paulo.

MATTHEW, C.; ASSUERO, S.G.; BLACK, C.K.; SACKVILLE HAMILTON, N.R. Tiller dynamics of grazed swards. In: LEMAIRE, G.; HODGSON, J.; MORAES, A.; CARVALHO, P.C.F.; NABINGER, C. (Ed.) Grassland ecophysiology and grazing ecology. Wallington: CAB International, 2000. cap.7, p.127-150.

MATTHEW, C.; LEMAIRE, G.; SACKVILLE HAMILTON, N.R.; HERNANDEZ-GARAY, A. A modified self-thinning equation to describe size/density relationships for defoliated swards. Annals of Botany, v.76, p.579-587, 1995.

MAZZANTI, A.; LEMAIRE, G.; GASTAL, F. The effect of nitrogen fertilisation upon the herbage production of tall fescue swards continuously grazed with sheep. 1. Herbage growth dynamics. Grass and Forage Science, v.49, p.111-120, 1994.

McDONALD, A.J.; ERICSSON, T.; LARSSON, C.M. Plant nutrition, dry matter gain and partitioning at the whole plant level. Journal of Experimental Botany, v.47, p.1245-1253, 1996.

METZGER, J. D. The functioning of hormones in plant growth and development. Hormones and reproductive development. In: DAVIES, P. J. (Ed.) Plant hormones: physiology, biochemistry and molecular biology. Dordrecht: Kluwer Academic, 1995. p.617-648.

MILLARD, P.; NIELSEN, G.H. The influence of nitrogen supply on the uptake and remobilization of stored N for the seasonal growth of apple trees. Annals of Botany, v.63, p.301-309, 1989.

MINCHIN, P.E.H.; THORPE, M.R. What determines carbon partitioning between competing sinks? Journal of Experimental Botany, v.47, p.1293-1296, 1996.

MINCHIN, P.E.H.; THORPE, M.R.; FARRAR, J.F. Short-term control of root:shoot partitioning. Journal of Experimental Botany, v.45, p.615-622, 1994.

MORGAN, P.W.; GUY, L.W.; PAO, C. Genetic regulation of development in Sorghum bicolor.

Plant Physiology, v.83, p.448-450, 1987. 
NELSON, C.J.; ZARROUGH, K.M. Tiller density and tiller weight as yield determinants of vegetative swards. In: WRIGHT, C.E. Plant physiology and herbage production. Belfast: British Grassland Society, 1981. cap.1, p.25-29.

NIJS, I.; IMPENS, I. An analysis of the balance between root and shoot activity in Lolium perenne cv. Melvina. Effects of $\mathrm{CO}_{2}$ concentration and air temperature. New Phytologist, v.135, p.81-91, 1997.

OCKERBY, S.E.; MIDMORE, D.J.; YULE, D.F. Timing and height of defoliation affect vegetative growth and floral development in grain sorghum. Australian Journal of Agricultural Research, v.52, p.801-808, 2001.

OLFF, H. Effects of light and nutrient availability on dry matter and $\mathrm{N}$ allocation in six successional grassland species. Oecologia, v.89, p.412-421, 1992.

OSAWA, A.; SUGITA, S. The self-thinning rule: another interpretation of Weller's results. Ecology, v.70, p.279-283, 1989.

OURRY, A.; KIM, T.H.; BOUCAUD, J. Nitrogen reserve mobilisation during regrowth of Medicago sativa L. Plant Physiology, v.105, p.831-837, 1994.

PARSONS, A.J.; ROBSON, M.J. Seasonal changes in the physiology of S24 perennial ryegrass (Lolium perenne L.). 3. Partitioning of assimilates between root and shoot during the transition from vegetative to reproductive growth. Annals of Botany, v.48, p.733-744, 1981.

PARSONS, A.J.; JOHNSON, J.R.; HARVEY, A. Use of a model to optimise the interaction between frequency and severity of intermittent defoliation and to provide a fundamental comparison of the continuous and intermittent defoliation of grass. Grass and Forage Science, v.43, p.49-59, 1988.

PATTERSON, D.T.; RUSSEL, A.E.; MORTENSEN, D.A.; COFFIN, R.D.; FLINT, E.P. Effects of temperature and photoperiod on Texas panicum (Panicum texanum) and wild proso millet (Panicum miliaceum). Weed Science, v.34, p.876-882, 1986.

PATRICK, J.W. Sieve element unloading: cellular pathway, mechanism and control. Physiologia Plantarum, v.78, p.298-308, 1990.

PEDREIRA, C.G.; MELLO, A.C.L.; OTANI, L. O processo de produção de forragem em pastagens. In: MATTOS, W.R.S; FARIA, V.P.; SILVE, S.C.; NUSSIO, L.G.; MOURA, J.C. (Ed.) A produção animal na visão dos brasileiros. Piracicaba: SBZ, 2001. cap. 53, p.772-807. 
PENATI, M.A.; SANTOS, P.M.; CASTRO, P.R.C. Avaliação da aplicação de reguladores vegetais sobre o desenvolvimento do capim Tanzânia (Panicum maximum Jacq.) (compact disc). In: REUNIÃO ANUAL DA SOCIEDADE BRASILEIRA DE ZOOTECNIA, 37., Viçosa, 2000. Anais. Viçosa: SBZ, 2000.

PENATI, M.A.; MAYA, F.L.A.; CORSI, M.; BALSALOBRE, M.A.A.; SANTOS, P.M.; PAGOTTO, D.; BARIONI, L.G.; MARTHA JÚNIOR, G.B. Resposta da taxa de lotação animal em pastagem irrigada de capim tanzânia manejada em três níveis de massa de forragem pós-pastejo. In: REUNIÃO ANUAL DA SOCIEDADE BRASILEIRA DE ZOOTECNIA, 38., Piracicaba, 2001. Anais. Piracicaba: SBZ, 2001. p.346-348.

PERRY, M.W.; D'ANTUONO, M.F. Yield improvement and associated characteristics of some Australian spring wheat cultivars introduced between 1860 and 1982. Australian Journal of Agricultural Research, v.40, p.457-472, 1989.

POPPI, D.P.; MINSON, D.J.; TERNOUTH, J.H. Studies of cattle and sheep eating leaf and stem fractions of grasses. I. The voluntary intake, digestibility and retention time in the reticulo-rumen. . Australian Journal of Agricultural Research, v.32, p.99-108, 1981.

PRESTON, K.A. The effects of developmental stage and source leaf position on integration and sectorial patterns of carbohydrate movement in an annual plant, Perilla frutescens (Lamiaceae). American Journal of Botany, v.85, p.1695-1703, 1998.

QUADROS, D.G.; RODRIGUES, L.R.A.; FAVORETTO, V.; MALHEIROS, E.B.; RAMOS, A.K.B. Perdas de forragem em pastagens dos cvs. Tanzânia e Mombaça de Panicum maximum Jacq. adubados com quatro doses de N, P e K. In: REUNIÃO ANUAL DA SOCIEDADE BRASILEIRA DE ZOOTECNIA, 38., Piracicaba, 2001. Anais. Piracicaba: SBZ, 2001. p.294-296.

QUEIROZ NETO, F.; MARTHA JR., G.B.; PENATI, M.A.; CORSI, M.; MENEZES, M.J.T. Impact of increasing nitrogen fertiliser rates upon an irrigated tanzania grass pasture. 1. Dry matter yield. In: INTERNATIONAL GRASSLAND CONGRESS, 19., São Pedro, 2001. Proceedings. Piracicaba: FEALQ, 2001. p.209-210. 
REGO, F.C.A.; CECATO, U.; CANTO, M.W.; MARTINS, E.N.; MIRA, R.; SANTOS, G.T.; CANO, C.P. Qualidade do capim tanzânia (Panicum maximum Jacq. cv. Tanzânia-1) manejado em diferentes alturas, sob pastejo. In: REUNIÃO ANUAL DA SOCIEDADE BRASILEIRA DE ZOOTECNIA, 38., Piracicaba, 2001. Anais. Piracicaba: SBZ, 2001. p.117-118.

RICHARDS, J.H.; MUELLER, R.J.; MOTT, J.J. Tillering in tussock grasses in relation to defoliation and apical bud removal. Annals of Botany, v.62, p.173-179, 1988.

ROBERTS, C.A.; MOORE, K.J. Chemical regulation of tall fescue reproductive development and quality with amidochlor. Agronomy Journal, v. 82, p.523-526, 1990.

ROSSETO, F.A.A. Desempenho agronômico de pastagens de capim elefante cv. Guaçu (Pennisetum purpureum Schum.) e capim tanzânia (Panicum maximum Jacq.) em sistemas de produção de leite. Piracicaba, 2000. 144 p. Dissertação (Mestrado) - Escola Superior de Agricultura “Luiz de Queiroz”, Universidade de São Paulo.

S.A.S. INSTITUTE. SAS User's guide : statistics. Cary, 1990. 956p.

SAAB, I.N.; SHARP, R.E.; PRITCHARD, J.; VOETBERG, G.S. Increased endogenous abscisic acid maintains primary root growth and inhibits growth of maize seedlings at low water potentials. Plant Physiology, v.93, p.1329-1336, 1990.

SAARINEN, T.; HAANSUU, P. Shoot density of Carex rostrata Stokes. in relation to internal carbon : nitrogen balance. Oecologia, v.122, p.29-35, 2000.

SANTOS, B.M.; MORALES-PAYAN, J.P.; STALL, W.M.; BEWICK, T.A.; SHILLING, D.G. Effects of shading on the growth of nutsedges (Cyperus spp.). Weed Science, v.45, p.670673, 1997.

SANTOS, P.M. Estudo de algumas características agronômicas de Panicum maximum (Jacq.) cvs. Tanzânia e Mombaça para estabelecer seu manejo. Piracicaba, 1997. 62p. Dissertação (Mestrado) - Escola Superior de Agricultura “Luiz de Queiroz”, Universidade de São Paulo.

SANTOS, P.M.; BALSALOBRE, M.A.A.; CORSI, M. Efeito da freqüência de pastejo e da época do ano sobre a produção e a qualidade em Panicum maximum cvs. Tanzânia e Mombaça. Revista Brasileira de Zootecnia, v.28, p.244-249, 1999.

SAVIDAN, Y.H.; JANK, L.; COSTA, J.C.G. Registro de 25 acessos selecionados de Panicum maximum. Campo Grande: EMBRAPA, CNPGC, 1990. 68p. (EMBRAPA. CNPGC. Documentos, 44). 
SCHNYDER, H.; VISSER, R. Fluxes of reserve-derived and currently assimilated carbon and nitrogen in perennial ryegrass recovering from defoliation. The regrowing tiller and its component functionally distinct zones. Plant Physiology, v.119, p.1423-1435, 1999.

SCHULZ, A. Phloem transport and differential unloading in pea seedlings after source and sink manipulations. Planta, v.192, p.239-248, 1994.

SINGH, D.K. Effects of cutting management on yield and quality of different selections of guinea grass (Panicum maximum, Jacq.) in a humid subtropical environment. Tropical Agriculture, v.72, p.181-187, 1995.

SKINNER, R.H.; MORGAN, J.A.; HANSON, J.D. Carbon and nitrogen reserve remobilization following defoliation: nitrogen and elevated $\mathrm{CO}_{2}$ effects. Crop Science, v.39, p.1749-1756, 1999.

SOLLENBERGER, L.E.; BURNS, J.C. Canopy characteristics, ingestive behaviour and herbage intake in cultivated tropical grasslands. In: INTERNATIONAL GRASSLAND CONGRESS, 19., São Pedro, 2001. Proceedings. Piracicaba: FEALQ, 2001. p.321-327.

TAIZ, L.; ZEIGER, E. Plant physiology. Redwood: The Benjamin/Cummings, 1991. 565p.

TALLOWIN, J.R.B.; WILLIAMS, J.H.H.; KIRKHAM, F.W. Some consequences of imposing different continuous-grazing pressures in the spring on tiller demography and leaf growth. Journal of Agricultural Science, v.112, p.115-122, 1989.

TAMASSIA, L.F.M.; MONTEIRO, F.A.; MANARIN, C.A.; GUIMARÃES, G.F.P.B.; PREMAZZI, L.M. Interação entre doses de nitrogênio e de enxofre para o estabelecimento e perfilhamento do capim tanzânia (compact disc). In: REUNIÃO ANUAL DA SOCIEDADE BRASILEIRA DE ZOOTECNIA, 36., Porto Alegre, 1999. Anais. Porto Alegre: SBZ, 1999.

THORNTON, B.; BAUSENWEIN, U. Seasonal protease activity in storage tissue of the deciduous grass Molinia caerulea. New Phytologist, v.146, p.75-81, 2000.

THORNTON, B.; MILLARD, P. Increased defoliation frequency depletes remobilization of nitrogen for leaf growth in grasses. Annals of Botany, v.80, p.89-95, 1997.

THORNTON, B.; MILLARD, P.; DUFF, E.I. Effects of nitrogen supply on the source of nitrogen used for regrowth of laminae after defoliation of four grass species. New Phytologist, v.128, p.615-620, 1994. 
THORNTON, B.; MILLARD, P.; DUFF, E.I.; BUCKLAND, S.T. The relative contribution of remobilization and root uptake in supplying nitrogen after defoliation for regrowth of laminae in four grass species. New Phytologist, v.124, p.689-694, 1993.

TILLEY, J.M.A.; TERRY, R.A. A two stage technique for the in vitro digestion of forage crops. Journal of the British Grassland Society, v.18, p.104-111, 1963.

TOMPSETT, P.B. Factors affecting the flowering of Andropogon gayanus Kunth. Responses to photoperiod, temperature and growth regulators. Annals of Botany, v.40, p.695-705, 1976.

TURGEON, R. The sink-source transition in leaves. Annual Reviews in Plant Physiology and Plant Molecular Biology, v.40, p.119-138, 1989.

TURNER, K.E.; PATERSON, J.A.; KERLEY, M.S.; FORWOOD, J.R. Mefluide treatment of tall fescue pastures: intake and animal performance. Journal of Animal Science, v.68, p.3399-3405, 1990.

VOUILLOT, M.; DEVIENNE-BARRET, F. Accumulation and remobilization of nitrogen in a vegetative winter wheat crop during or following nitrogen deficiency. Annals of Botany, v.83, p.569-575, 1999.

WALKER, R.L.; BURNS, I.G.; MOORBY, J. Responses of plant growth rate to nitrogen supply: a comparison of relative addition and $\mathrm{N}$ interruption treatments. Journal of Experimental Botany, v.52, p.309-317, 2001.

WARDLAW, I.F. Transley review no. 27. The control of carbon partitioning in plants. New Phytologist, v.116, p.341-381, 1990.

WELLER, D.E. Self-thinning exponent correlated with allometric measures of plant geometry. Ecology, v.68, p.813-821, 1987.

WELLER, D.E. Will the real self-thinning rule please stand up?-A reply to Osawa and Sugita. Ecology, v.71, p.2004-2007, 1990.

WILSON, D.; JONES, J.G. Effect of selection for dark respiration rate of mature leaves on crop yields of Lolium perenne cv. S23. Annals of Botany, v.49, p. 313-320, 1982.

WILSON, J.B. A review of evidence on the control of shoot:root ratio, in relation to models. Annals of Botany, v.61, p.433-449, 1988.

WILSON, J. R. Organisation of plant tissues. In: JUNG, H.G.; BUXTON, D.R.; HATFIELD, R.D.; RALPH, J. (Ed.) Forage cell wall structure and digestibility. Madison: ASA; CSSA; SSSA, 1993. cap.1, p.1-27. 
WILSON, J.R. Variation of leaf characteristics with level of insertion on a grass tiller. 1. Development rate, chemical composition and dry matter digestibility. Australian Journal of Agricultural Research, v.27, p.343-354, 1976.

WILSON, J.R.; WONG, C.C. Effects of shade on some factors influencing nutritive quality of green panicum and siratro pastures. Australian Journal of Agricultural Research, v.33, p.937-949, 1982.

ZIMMER, A.H.; FAVORETTO, V.; GUIDEL, C.; MALHEIROS, E.; LEMPP, B. Perfilhamento e índice de área foliar remanescente dos capins aruana e vencedor (Panicum maximum), sob dois níveis de resíduos de pastejo e dois níveis de nitrogênio (compact disc). In: REUNIÃO ANUAL DA SOCIEDADE BRASILEIRA DE ZOOTECNIA, 36., Porto Alegre, 1999. Anais. Porto Alegre: SBZ, 1999. 